VILNIAUS GEDIMINO TECHNIKOS UNIVERSITETAS

Raimundas JUNEVIČIUS

TRANSPORTO SRAUTUY MODELIAVIMAS SUTELKTUUJŲ PARAMETRŲ METODU GATVIŲ TINKLE

DAKTARO DISERTACIJA

TECHNOLOGIJOS MOKSLAI,

TRANSPORTO INŽINERIJA (03T)

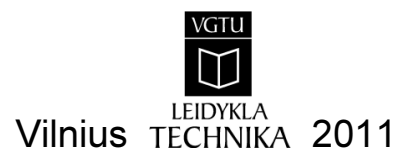


Disertacija rengta 2005-2011 metais Vilniaus Gedimino technikos universitete.

Disertacija ginama eksternu.

\section{Mokslinis konsultantas}

prof. habil. dr. Marijonas BOGDEVIČIUS (Vilniaus Gedimino technikos universitetas, transporto inžinerija - 03T).

Vilniaus Gedimino technikos universiteto Transporto inžinerijos mokslo krypties disertacijos gynimo taryba:

\section{Pirmininkas}

prof. habil. dr. Adolfas BAUBLYS (Vilniaus Gedimino technikos universitetas, transporto inžinerija $-03 \mathrm{~T})$.

\section{Nariai:}

prof. dr. Žilvinas BAZARAS (Kauno technologijos universitetas, transporto inžinerija - 03T),

prof. habil. dr. Andrii BIELIATYNSKYI (Nacionalinis aviacijos universitetas, Ukraina, transporto inžinerija - 03T),

prof. dr. Marija BURINSKIENE் (Vilniaus Gedimino technikos universitetas, statybos inžinerija - 02T),

doc. dr. Saugirdas PUKALSKAS (Vilniaus Gedimino technikos universitetas, transporto inžinerija - 03T).

Disertacija bus ginama viešame Transporto inžinerijos mokslo krypties disertacijos gynimo tarybos posėdyje 2011 m. gruodžio 5 d. 14 val. Vilniaus Gedimino technikos universiteto senato posėdžių salëje.

Adresas: Sauletekio al. 11, LT-10223 Vilnius, Lietuva.

Tel.: (8 5) 274 4956; faksas (8 5) 270 0112; el. paštas doktor@vgtu.lt

Pranešimai apie numatomą ginti disertaciją išsiusti $2011 \mathrm{~m}$. lapkričio $4 \mathrm{~d}$.

Disertaciją galima peržiūrèti interneto svetainèje http://dspace.vgtu.lt/ ir Vilniaus Gedimino technikos universiteto bibliotekoje (Sauletekio al. 14, LT-10223 Vilnius, Lietuva).

VGTU leidyklos TECHNIKA 1919-M mokslo literatūros knyga

ISBN 978-609-457-001-8

(C) VGTU leidykla TECHNIKA, 2011

(C) Raimundas Junevičius, 2011

raimundas.junevicius@vgtu.lt 
VILNIUS GEDIMINAS TECHNICAL UNIVERSITY

Raimundas JUNEVIČIUS

MODELING OF THE TRAFFIC FLOWS

USING THE METHOD OF THE

CONCENTRATED PARAMETERS IN THE STREETS NETWORK

DOCTORAL DISSERTATION

TECHNOLOGICAL SCIENCES,

TRANSPORT ENGINEERING (03T)

Vilnius $\frac{\text { VGTU }}{\substack{\text { LEIDYKLA } \\ \text { TECHNIKA } 2011}}$ 
Doctoral dissertation was prepared at Vilnius Gediminas Technical University in 2005-2011.

The dissertation is defended as an external work.

\section{Scientific Consultant}

Prof Dr Habil Marijonas BOGDEVIČIUS (Vilnius Gediminas Technical University, Transport Engineering - 03T).

The Dissertation Defense Council of Scientific Field of Transport Engineering of Vilnius Gediminas Technical University:

\section{Chairman}

Prof Dr Habil Adolfas BAUBLYS (Vilnius Gediminas Technical University, Transport Engineering - 03T).

\section{Members:}

Prof Dr Žilvinas BAZARAS (Kaunas University of Technology, Transport Engineering - 03T),

Prof Dr Habil Andrii BIELIATYNSKYI (National Aviation University, Ukraine, Transport Engineering - 03T),

Prof Dr Marija BURINSKIENE (Vilnius Gediminas Technical University, Civil Engineering - 02T),

Assoc Prof Dr Saugirdas PUKALSKAS (Vilnius Gediminas Technical University, Transport Engineering - 03T).

The dissertation will be defended at the public meeting of the Dissertation Defense Council of Transport Engineering in the Senate Hall of Vilnius Gediminas Technical University at 2 p. m. on 5 December 2011.

Address: Saulètekio al. 11, LT-10223 Vilnius, Lithuania.

Tel.: +370 5274 4956; fax +370 5270 0112; e-mail: doktor@vgtu.lt

A notification on the intended defending of the dissertation was send on 4 November 2011.

A copy of the doctoral dissertation is available for review at the Internet website http://dspace.vgtu.lt/ and at the Library of Vilnius Gediminas Technical University (Sauletekio al. 14, LT-10223 Vilnius, Lithuania). 


\section{Reziumè}

Disertacijoje nagrinejjami transporto srautų matematiniai modeliai, siekiama sukurti universalu transporto srautų, kaip netiesinès dinaminès sistemos, sutelktujų parametrų matematinį modelį su vèlinimu, kuris būtų skirtas aprašyti transporto srautams miesto gatviu tinkle. Darbe tarpusavyje lyginami kontinuumo modeliai, paremti dujų kinetine ir hidrodinaminine teorija. Minètų modelių lygtys sprendžiamos charakteristikų ir baigtinių skirtumų metodais. Taip pat pristatomas sukurtas transporto srautu, kaip netiesinès dinaminès sistemos, sutelktujų parametrų modelis su vélinimu.

Disertaciją sudaro ịvadas, keturi skyriai, rezultatų apibendrinimas, naudotos literatūros ir autoriaus publikacijų disertacijos tema sąrašai.

Ivadiniame skyriuje aptariama tiriamoji problema, darbo aktualumas, aprašomas tyrimų objektas, formuluojamas darbo tikslas bei uždaviniai, aprašoma tyrimų metodika, darbo mokslinis naujumas, darbo rezultatų praktinè reikšmè, ginamieji teiginiai. Ivado pabaigoje pristatomos disertacijos tema autoriaus paskelbtos publikacijos ir pranešimai konferencijose bei disertacijos struktūra.

Pirmasis skyrius skirtas literatūros analizei. Jame pateikta kitų autorių matematinių modelių analizè ir pristatomos problemų nagrinèjimo kryptys.

Antrajame skyriuje pateiktas transporto srautu modelio, paremto dujų kinetine teorija matematinis aprašymas, jis pritaikytas spręsti charakteristiku metodu. Apibendrinamas ir pristatomas sukurtas universalus transporto srautu, kaip netiesinès dinaminès sistemos, sutelktujų parametrų modelis su vélinimu, ivertinantis sankryžas. Modelis tinkamas transporto srautams modeliuoti tiesioje kelio atkarpoje ir gatvių tinkle. Nagrinejjamos sprendinio stabilumo sąlygos.

Trečiajame skyriuje pateikiami matematinio eksperimento rezultatai modeliuojant: tiesią kelio atkarpą, sankryžą, miesto gatvių tinklą. Tarpusavyje lyginami du matematiniai modeliai, sprendžiant analogiškus uždavinius dviem skirtingais metodais.

Ketvirtajame skyriuje pristatomos tolesnių transporto srautų tyrimų gairès. Natūrinio eksperimento rezultatai lyginami su matematinio eksperimento rezultatais. Šiame skyriuje taip pat pateikiamas pavyzdys, kaip matematinị modelị galima pritaikyti praktiniams uždaviniams spręsti. Pateiktame pavyzdyje modeliuojama vidaus degimo variklių emisija tiesioje kelio atkarpoje.

Disertacijos tema yra atspausdinti 7 moksliniai straipsniai: trys - mokslo žurnaluose, ịtrauktuose i Thomson ISI sąrašą; 1 - recenzuojamų tarptautinių konferencijų medžiagoje, trys - kitose tarptautinių ir respublikinių konferencijų medžiagose. 


\section{Abstract}

Mathematical models of traffic flows are under investigation in this scientific doctoral dissertation. A universe mathematical model to model city traffic flow is presented. Traffic flow models are described and the possibility of the usage of these models to control or redistribute city traffic is shown. New method of the traffic flow as nonlinear dynamic system based on the concentrated parameters with the time delay is presented. Continuum traffic flow model based on the Gas Kinetic theory is compared with the new one. Equations of these models are solved using characteristic and the Runge-Kutta methods.

Thesis includes an introduction, four chapters, conclusions, the list of the used literature and the list of publications of the dissertation author. The object of the study, problem of investigation, actuality is described in the introduction. There are presented: research methodology, scientific novelty, research methods, topicality of the thesis. The introduction is finalised with the list of publications and the structure of the dissertation.

Analysis of the mathematical models and problematic aspects of the modeling are presented in first chapter.

Equations of Kinetic traffic flow model are rewritten in the algebraic form and are prepared to solve using characteristic method is presented. New traffic flow, as nonlinear dynamic system, model with the concentrated parameters is presented. This model derives straight road parts and intersections of a city network. The stability of the solution is analyzed.

The solution of the theoretical model which is described in the section two is presented in the section three. Mathematical experiments are made on the straight road section and the traffic flow network using two models, kinetic theory and the new theory. The modeling results are listed in the pictures of this section.

Chapter four makes a comparison between experimental and simulation results and provides with an example of applying the mode in practice. There are compared measured and simulated traffic flow parameters. Internal conbustion engine's emission simulation is presented as an example to show the possibility of usage of the model.

The subject matter of the above presented thesis was discussed in 7 scientific articles: three articles were published in the Thomson ISI Web of Science journals, one - in the ISI Proceedings, one - in the peer-reviewed material of the international conference and two - in the material of other national and international conferences. 


\section{Žymëjimai}

\section{Simboliai}

$k$ - transporto srauto koncentracija, auto/m;

$v$ - transporto srauto greitis, $\mathrm{m} / \mathrm{s}$;

$L_{i-1, i}-$ kelio (gatvès) segmento prieš tašką $i$ ilgis, m;

$L_{i+1, i}-$ kelio (gatvès) segmento po taško $i$ ilgis, m;

$k_{\text {max }, i}-$ didžiausia leistina transporto srauto koncentracija kelio (gatvès) mazge $i$, auto/m;

$k_{i}$ - transporto srauto koncentracija kelio (gatvès) mazge $i$, auto/m;

$v_{\max , i}-$ didžiausias leistinas transporto srauto greitis kelio (gatvès) mazge $i, \mathrm{~m} / \mathrm{s}$;

$v_{i}$ - transporto srauto greitis kelio (gatvès) mazge $i, \mathrm{~m} / \mathrm{s}$;

$a_{\max , i}-$ didžiausias leistinas transporto srauto intensyvumas kelio (gatvès) mazge $i$, auto/s;

$a_{i}$ - transporto srauto intensyvumas kelio (gatvès) mazge $i$, auto/s;

$r_{k, i n}$ - funkcija, priklausanti nuo transporto srauto parametrų patenkančių i mazgą $i$ ir ivedanti pataisą koncentracijos reikšmei;

$r_{k, o u t}$ - funkcija, priklausanti nuo transporto srauto parametrų išeinančių iš mazgo $i$ ir ivedanti pataisą koncentracijos reikšmei;

$r_{v, \text { in }}-$ funkcija, priklausanti nuo transporto srauto parametrų patenkančių į mazgą $i$ ir ịvedanti pataisą greičio reikšmei;

$r_{v, \text { out }}$ - funkcija, priklausanti nuo transporto srauto parametrų išeinančių iš mazgo $i$ ir ivedanti pataisą greičio reikšmei; 
$\tau$ - laiko tarpas, kuris reikalingas nuvažiuoti atstumą $L_{i-1, i}$ arba $L_{i+1, i}, \mathrm{~s}$; $f_{i}\left(k_{i+1, i}\right)$ - funkcija, priklausanti nuo parametro $k$ ir užrašoma mazgui $i$; $p_{i n}(t)$ - tikimybè, jog srautas pateks ị $i+1$ segmentą iš prieš mazgą $i$ esančio kelio (gatvès) segmento;

$p_{\text {out }}(t)$ - tikimybè, jog srautas paliks $i-1$ segmentą ir pateks ị sekantị po mazgą $i$ kelio (gatvès) segmentą.

\section{Santrumpos}

CHM - dujų kinetinės transporto srautų teorijos modelis, sprendžiamas charakteristiku metodu

LWR - Lighthill-Whitham ir Richards matematinis modelis transporto srautams modeliuoti, sukurtas naudojantis hidrodinamine teorija;

MM - matematiniai modeliai;

SPM - sukurtas transporto srautų, kaip netiesinès dinaminès sistemos, sutelktujų parametrų modelis su vèlinimu, sprendžiama Rungès ir Kuto metodu;

$\mathrm{TP}$ - transporto priemone;

TS - Transporto srautas;

VDV - vidaus degimo variklis.

\section{Sąvokos}

Išeinanti eismo juosta - eismo juosta, kuri išeina iš sankryžos;

İeinanti eismo juosta - eismo juosta, kuri įeina ị sankryžą;

Konfliktinis sankryžos taškas - taškas, kuriame susikerta dvi ar daugiau eismo juostų;

Kontinuumo matematinis modelis - matematinis modelis, kuriame transporto srautai aprašomi kaip vientisas kūnas, kurio parametrų (koncentracijos ir greičio) pokytis, kiekviename eismo juostos mazge, itakoja vienas kito reikšmes;

Nestabili transporto srauto būsena - būsena, kai, esant tokiai pačiai koncentracijai transporto srauto greitis gali kisti plačiame intervale;

Sutelktieji parametrai - tai parametrai, kurių reikšmės, iš tam tikro ilgio eismo juostos atkarpos sutelkiami ị tašką. Šie taškai išdesstomi ant eismo juostos tam tikru atstumu vienas nuo kito;

Transporto srauto intensyvumas - transporto priemonių, pervažiuojančių gatvės pjūvių per nustatytą laiko tarpą, skaičius;

Transporto srauto koncentracija - automobilių skaičius tam tikro ilgio eismo juostos atkarpoje. 


\section{Turinys}

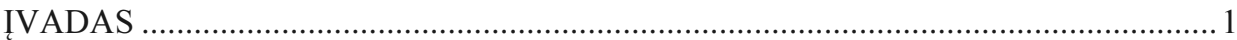

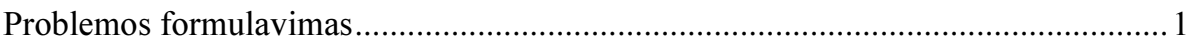

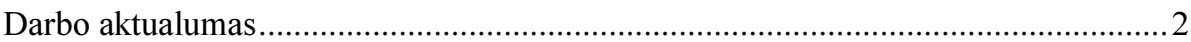

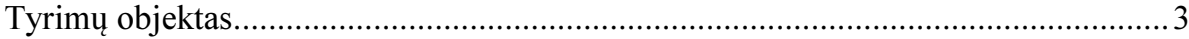

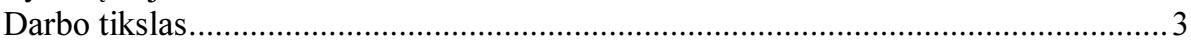

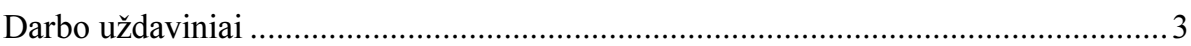

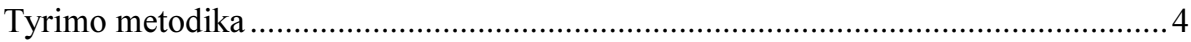

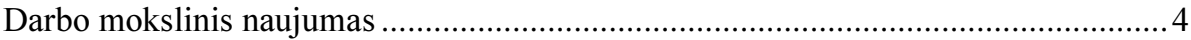

Darbo rezultatų praktinè reikšmè ................................................................... 4

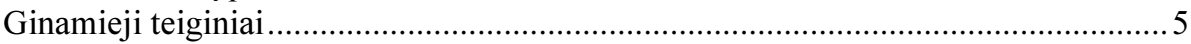

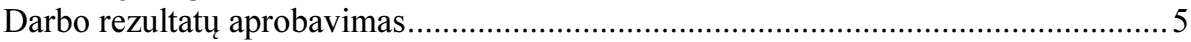

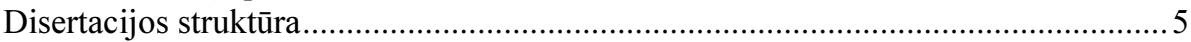

1. MOKSLINĖS LITERATŪROS ANALIZĖ. TRANSPORTO SRAUTŲ

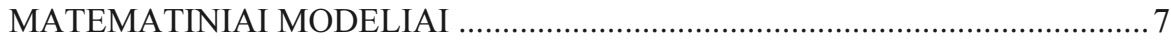

1.1. Diskretiniai transporto srautų matematiniai modeliai........................................... 7

1.2. Automobilių sekimo paskui automobilius matematiniai modeliai ....................... 9

1.3. Kontinuumo matematiniai modeliai ............................................................... 10

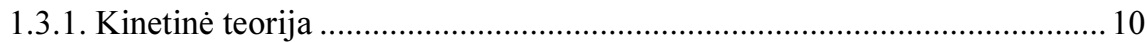

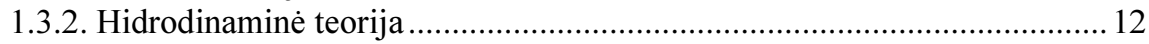

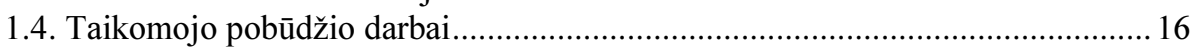

1.5. Pirmo skyriaus išvados ir darbo uždavinių formulavimas................................... 18 
2. SUKURTO TRANSPORTO SRAUTO MATEMATINIO MODELIO TYRIMAS .. 21

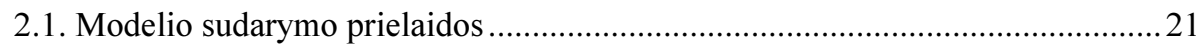

2.1.1. Prielaidos tiesiai gatvès eismo juostai aprašyti ..................................... 21

2.1.2. Prielaidose eismo juostų susikirtimams aprašyti.....................................23

2.2. Klasikinès matematinės išraiškos, aprašančios kontinuumo modelius ..............27

2.2.1. Dujų kinetinė transporto srautų teorija............................................. 27

2.2.2. Dujų kinetinès transporto srautų teorijos lygčių sprendimo stabilumas..... 30

2.3. Teorinis sutelktụjų parametrų automobilių transporto srautų modelis ............... 31

2.3.1. Naujo matematinio modelio idejos apibendrinimas. Matematinių išraiškų formulavimas ............................................................................... 31

2.3.2. Sukurto metodo pritaikymas transporto srautams modeliuoti sankryžose. 36

2.3.3. Automobilių transporto srautų, kaip netiesinès dinaminès sistemos, modelio lygčių stabilumo įvertinimas......................................................... 38

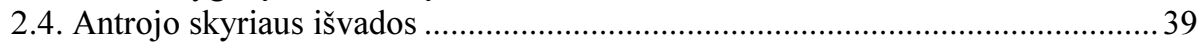

3.TRANSPORTO SRAUTŲ MATEMATINIŲ MODELIŲ IR EKSPERIMENTŲ REZULTATU PALYGINIMAS ........................................................................ 41

3.1. Tiesios kelio atkarpos modeliavimas pasitelkiant klasikinių automobilių transporto srautu modelių lygtis

3.2. Tiesios kelio atkarpos modeliavimas pasitelkiant sutelktujų parametrų automobilių transporto srautų modelio lygtis

3.3. Dujų kinetinio matematinio modelio ir sutelktụų parametrų matematinio modelio palyginimas

3.4. Koncentruotu parametrų metodo pritaikymas transporto srautams modeliuoti miesto tinkle

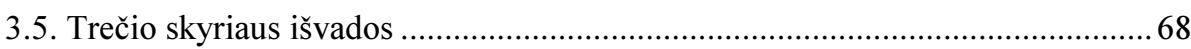

4. MATEMATINIO MODELIO REZULTATŲ IR EKSPERIMENTINIŲ DUOMENŲ

PALYGINIMAS. MODELIO PRITAIKYMO GALIMYBÉS

4.1. Modeliavimo rezultatų ir eksperimentinių duomenu palyginimas ....................69

4.2. Vidaus degimo variklio generuojamos emisijos modeliavimas tiesioje kelio atkarpoje pasitelkiant transporto sraytų matematinius modelius ..................... 75

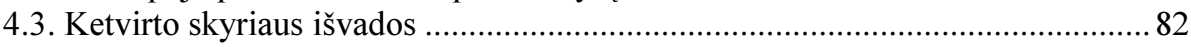

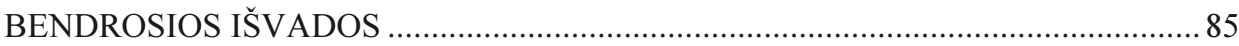

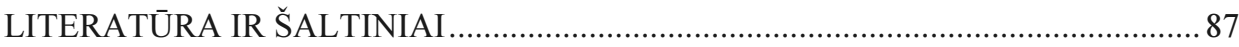

AUTORIAUS PUBLIKACIJŲ DISERTACIJOS TEMA SĄRAŠAS ......................... 93

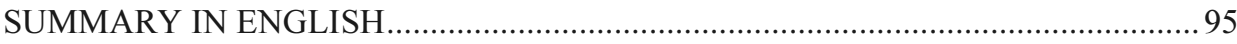

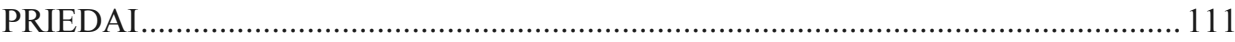

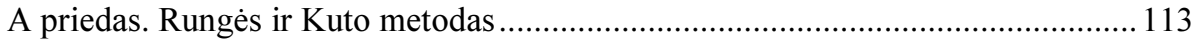

B priedas. Niutono metodas ....................................................................... 115

C priedas. Sukurto modelio kodas FORTRAN programine kalba ....................... 116

D priedas. Vidaus degimo variklio emisijų prognozès rezultatai ........................... 127

E priedas. Bendraautorių sutikimai teikti publikacijų medžiagą disertacijoje......... 131

F priedas. Mokslinių publikacijų disertacijos tema kopijos ................................. 132 


\section{Content}

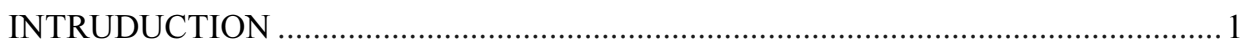

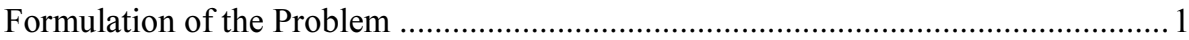

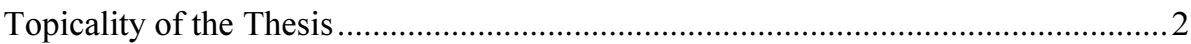

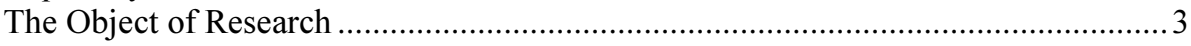

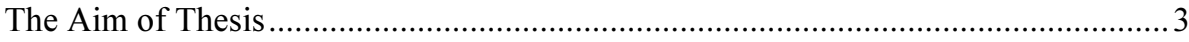

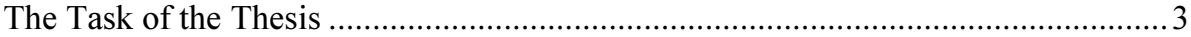

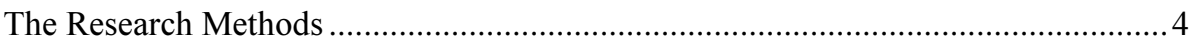

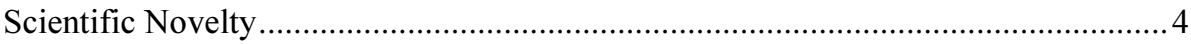

Practical Significance of the Obtained Results........................................................... 4

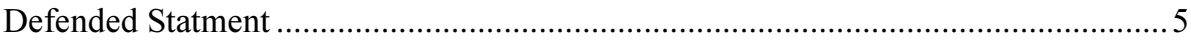

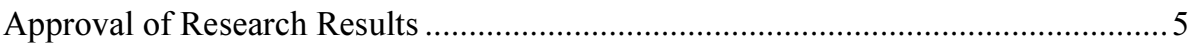

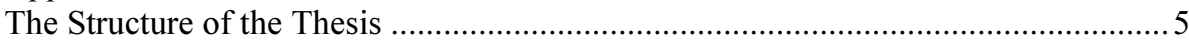

1. ANALYSIS OF SCIENTIFIC LITERATURE. TRAFFIC FLOWS

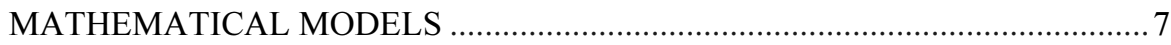

1.1. Discrete Traffic Flow Mathematical Models..................................................... 7

1.2. Folow the Leader Mathematical Models ......................................................... 9

1.3. Continnuum Mathematical Models ................................................................. 10

1.3.1. Kinetic Theory …………………......................................................... 10

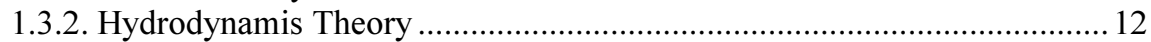

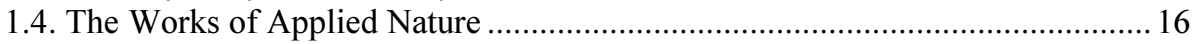

1.5. Conclusions of the First Chapter and the Formation of the Tasks....................... 18 
2. THE INVESTIGATION OF THE CREATED TRAFFIC FLOWS MODELS ..........21

2.1. The Assumptions of the Model ....................................................................... 21

2.1.1. The Assumptions to Derive Stright Road ............................................... 21

2.1.2. The Assumptions to Derive Intersections ................................................23

2.2. Classic Mathematical Equations of the Traffic Flows ......................................27

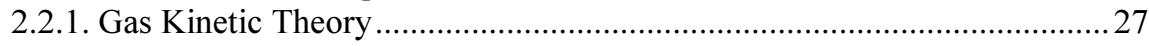

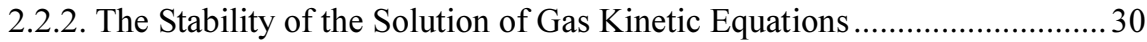

2.3. Traffic Flow Model of Concentrated Parameters ............................................ 31

2.3.1. The Idea of the New Model. The Derivation of the Equations .................. 31

2.3.2. Application of the Created Method to Model Traffic Flows at the

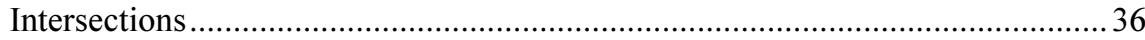

2.3.3. The Stability of the Solution of Created Method ...................................... 38

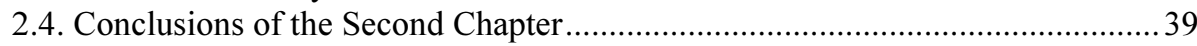

3. COMPARITION OF MATHEMATICAL MODELS FOR TRAFFIC FLOWS

AND EXPERIMENTAL RESULTS ............................................................. 41

3.1. Modeling of the Stright Road Section Using Classic Traffic Flows Models...... 41

3.2. Modeling of the Stright Road Section Using Method of Concentrated

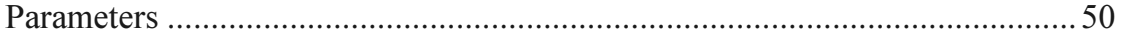

3.3. Comparition of the Results of Two Metgods the Gas Kinetik and the Method of Concentrated Parameters............................................................... 57

3.4. Application of the Method of Concentrated Parameters to Model Traffic

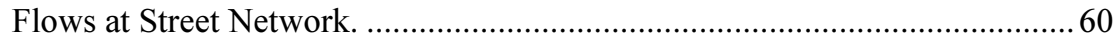

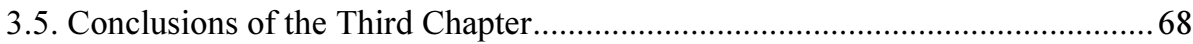

4. COMPARISON OF THE RESULTS OF THE MATHEMATICAL MODEL

AND EXPERIMENTAL DATA. POSSIBILITIES OF THE APPLICATION

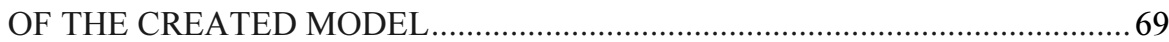

4.1. Comparition of the Results tf Mathematical Model and Experimental Data......69

4.2. Modelling of Internal Combustion Engines' Emission Through the Use of

Traffic Flow Mathematical Models …...................................................... 75

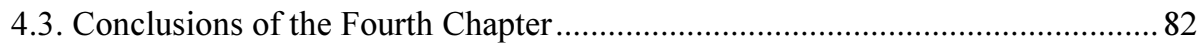

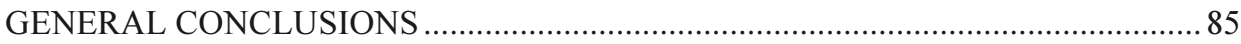

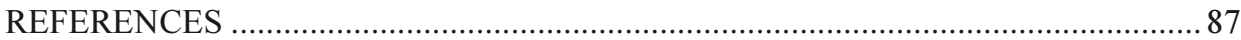

LIST OF PUBLICATIONS BY THE AUTHOR ON THE TOPIC OF THE

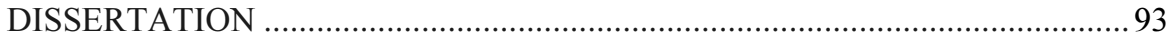

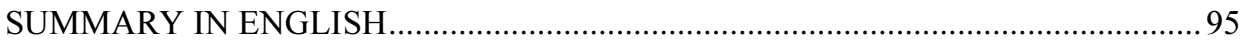

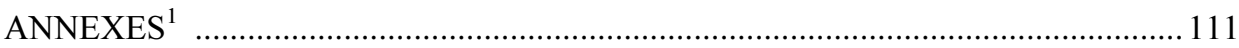

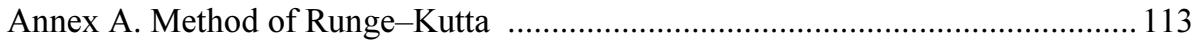

Annex B. Method of Newton ............................................................................. 113

Annex C. Algorithm of Created Program in FORTRAN Language ........................ 116

\footnotetext{
${ }^{1}$ The annexes are supplied in the enclosed compact disc

xii
} 
Annex D. Results of the Forecasts of Internal Combustions Engine Emisions 127

Annex E. The Agreements of Couthors to Present Publications for the Dissertation Defence

Annex F. Copies of Scientific Publications by the Author on the topic of the Dissertation. 



\section{Ivadas}

\section{Problemos formulavimas}

Tiriant transporto srautus naudojami ịvairūs tyrimo modeliai tarp jų ir matematiniai. Matematiniuose modeliavimo uždaviniuose sprendžiamas tinkamiausios esamoms sąlygoms funkcijos reikšmès parinkimas, t. y. galimybè. Tada, eismo valdymo sistemoms keliamas uždavinys - efektyvus eismo funkcionavimas (eismo intensyvumo maksimizavimas) ir eismo saugumas.

Šiuo metu transporto srautams tirti naudojami diskretiniai, kontinuumo, automobilių sekimo paskui automobilius matematiniai modeliai. Šie modeliai transporto srautą aprašo labai skirtingai. Didžioji matematinių modelių dalis nevertina staigaus važiavimo sąlygų pasikeitimo, o naudoja srauto parametrų reikšmes, kurios yra išmatuojamos per tam tikrą laiko tarpą ir apibendrinamos.

Norint įvertinti staigius važiavimo sąlygu pasikeitimus galima naudoti tradicinius kontinuumo modelius. Šie modeliai sudaryti naudojant lygtis su dalinėmis išvestinèmis yra tikslūs, tačiau šių modelių lygtys sunkiai sprendžiamos, o skaičiavimai užima daug laiko.

Siekiat palengvinti lygčių sprendimą neprarandant tikslumo reikètų naudoti modelị, kurio lygtys būtų lengvai sprendžiamos tradicinias skaitinias metodais.

Prognozuojant transporto srautų pasiskirstymą gatvių tinkle, staigiai pasikeitus važiavimo sąlygoms, galima tinkamai parinkti šviesoforų valdymo 
algoritmus, numatyti galimas grūstis gatvių tinkle ir pasiūlyti jų šalinimo strategijas, prognozuoti vibracijų, triukšmo, oro užterštumo kitimo tendencijas, keičiantis gatvių tinklo apkrovimui, ir siūlyti racionalias gatvių apkrovimo strategijas igyvendinant pasirinktas sąlygas.

\section{Darbo aktualumas}

Mokslinejje literatūroje transporto srautai tiriami naudojant įvairius metodus, tačiau, šie metodai yra labai skirtingi ir jų taikymas yra ribotas.

Mokslinė problema - ištirti bei moksliškai pagrịsti santykinai paprasto transporto srautų matematinio modelio taikymo, kai vertinami staigūs važiavimo sąlygu pasikeitimai gatvių tinkle, galimybes. Sukurta sistema padètų prognozuoti transporto poveikị aplinkai (oro užterštumas vidaus degimo varikliu deginiais, triukšmas, vibracijos, kelio dangos deformacijos, gatviu apkrovimo prognozavimas trumpame laiko intervale).

Mokslinès problemos ištyrimo lygis. Transporto srautų matematiniai modeliai ivvairiais aspektais nagrinèti tiek mūsų šalyje tiek ir užsienyje mokslininkų: Bazaras, J.; Bellucci, P.; Cipriani E.; Bonzani, I.; Burger, R.; Garcia, A.; Karlsen, K. H.; Towers J. D.; Chalons, C.; Goatin P.; Chowdhury, D.; Santen , L.; Schadschneider, A.; Colombo R.M.; Corli A.; Rosini M.D.; Dao, Z. Y.; Li, K. P.; Li, X. G.; Huang H. J. Mao B. H.; Garavello, M.; Piccoli, B.; Herty, M.; Kichner, C.; Klar, A. Ilgakojyte-Bazarienè, J.; Marškaitis, D.; Khalesian, M.; Phlavani, P.; Delavar, R. M.; Ni, D.; Leonard II, J. D.; Williams, B. M.; Nikolov, E.; Safonov, L. A.; Tomer, E.; Strygin, V. V.; Havlin, S.; Siebel, F.; Mauser W; Žiliūte, L.; Laurinavičius, A.; Vaitkus A.; Сильянов, В. B. ir kt. Mūsų šalies mokslininkai daugiau tiria praktinio pobūdžio problemas ir naudoja sukurtus paketus, transporto srautams modeliuoti, tokius kaip PTV vaision, EMME/2 ir kt. Daugelyje išvardintu autorių darbų, kuriuose nagrinejjami transporto srautus aprašantys matematiniai modeliai, pastebima, jog transporto srautai, priklausomai nuo automobilių kiekio tam tikroje kelio atkarpoje, gali būti stabilios ir nestabilios būsenos, o transporto srauto vidutinis greitis priklauso nuo TS koncentracijos.

Daugelis autorių matematiniuose modeliuose aprašo stabilią transporto srautų būseną. Automobilių srauto koncentracijos ir greičio parametrus susieja naudodami taip vadinamą „fundamentaliają kreivę“ - îveda automobilių srauto greičio pasiskirstymo nuo koncentracijos funkciją. Siekiant tiksliau sumodeliuoti transporto srautą reikia matematiškai aprašyti nestabiliają transporto srautų būseną. Todèl aprašant transporto srautus stengiamasi išskirti dvi srauto būsenas: stabili srauto fazè aprašoma tolygiai kintančia tiese, o nestabilios fazès zona aprašoma apribojant ją keliomis kreivèmis. 
Matematiškai modeliuojant automobilių transporto srautus gatvėse kontinuumo metodais pastebimi modeliavimo rezultatu netikslumai, kai eismas sankryžoje yra sustabdomas ir po kurio laiko vèl pradeda judèti. Tada modelio rezultatuose atsiranda informacijos tarp gretimų mazgų nesutapimas (Remano problema). Taip pat reikia spręsti srautų paskirstymo uždavinį sankryžoje išvengiant sistemos persipildymo. Sankryžų tipas ir eismo juostų skaičius sankryžoje sudaro papildomus sunkumus matemetiškai aprašant sankryžas. Jeigu sankryža yra reguliuojama, jos matematinis modelis santykinai paprastesnis, nes eismo srautų kryptis yra nustatoma vadovaujantis reguliavimo signalais. Nereguliuojamose sankryžose matematinis transporto srautų aprašymas yra sudetingesnis, nes reikia vertinti: eismo pirmumo sąlygas konfliktiniuose sankryžos taškuose, leistinus laiko intervalus priešpriešinès eismo juostos kirtimui ir kitus parametrus bei sąlygas. Šie parametrai tampa svarbūs, kai reikia nustatyti sąlygas, kurioms esant srautas gali būti nukreipiamas iš vienos eismo juostos i kitą, kai eismo juostų trajektorijos kertasi tarpusavyje.

Atsižvelgiant $i$ išvardintas problemas kyla būtinybè turèti pakankamai tikslų, lengvai pritaikomą skirtingiems transporto uždaviniams spręsti transporto srautų modelį, kurio lygtys būtų lengvai sprendžiamos skaitiniais metodais arba kelių tipų modelius nesunkiai būtų galima suderinti tarpusavyje konkrečios problemos sprendimui.

\section{Tyrimų objektas}

Darbo tyrimų objektas - transporto srauto, kaip netiesinès dinaminès sistemos, gatviu tinkle tyrimas, kai dèmesys skiriamas matematiniams metodams, kuriais šie srautai yra aprašomi ir paruošiami inžinerinėms problemoms spręsti.

\section{Darbo tikslas}

Sukurti universalų metodą, kuriuo būtų galima tyrinèti transporto srautus, nagrinejjant transporto srautą, kaip netiesinę dinaminę sistemą gatvių tinkle, staigiai pasikeitus važiavimo sąlygoms.

\section{Darbo uždaviniai}

Darbo tikslui pasiekti darbe sprendžiami šie uždaviniai:

1. Išanalizuoti esamus transporto srautų matematinius modelius. 
2. Pasiūlyti koncepciją naujo matematinio modelio sukūrimui, kuris užimtų tarpinę padètị tarp nagrinejjamų transporto srautų su diskretiniais ir kontinuumo elementais.

3. Sukurti naują matematini modeli transporto srautui, kaip netiesinei dinaminei sistemai su vèlavimu, modeliuoti.

4. Palyginti sukurtą ir tradicinį kontinuumo matematinius modelius.

5. Atlikti natūrini eksperimentą ir gautus duomenis apie transporto srauto parametrų pokyčius panaudoti sukurto modelio patikrinimui.

6. Pateikti pavyzdi kaip galima panaudoti sukurtą matematini modeli sprendžiant taikomojo pobūdžio uždavinius.

\section{Tyrimo metodika}

Darbe taikomi matematinio modeliavimo, eksperimentiniai tyrimo metodai.

\section{Darbo mokslinis naujumas}

Rengiant disertaciją buvo gauti šie Transporto inžinerijos mokslui nauji rezultatai:

1. Sukurtas sutelktujų parametrų matematinis modelis transporto srautams, kaip netiesinei dinaminei sistemai su vèlavimu tyrinèti.

2. Sukurtas būdas oro užterštumui vidaus degimo variklio deginiais prognozuoti, kai vertinamos srauto dinaminès charakteristikos ir automobilių kiekis gatvių tinkle.

\section{Darbo rezultatų praktinė reikšmè}

Tyrimų rezultatai leis tirti transporto srautus atskiruose eismo juostų ruožuose, sankryžose arba gatvių tinkle. Modelis ar jo elementai gali būti taikomi:

- optimalaus maršruto paieškai atlikti;

- miesto gatvių tinklo apkrovimui prognozuoti;

- transporto srautų perskirstymo miesto gatvių tinkle prognozės sudarymui, kai gatvès uždaromos rekonstrukcijai arba planuojamos nauju gatviu statybos;

- vidaus degimo variklių deginių emisijos prognozavimui;

- transporto srauto pasiskirstymo prognozei gatvių tinkle staigiai pasikeitus važiavimo sąlygoms. 


\section{Ginamieji teiginiai}

1. Transporto srautas gatvių tinkle gali būti nagrinejjamas, kaip netiesinè dinaminè sistema su vèlavimu ịvertinant staigiai pasikeitusias važiavimo sąlygas ir gatvių tinklo parametrus.

2. Oro užterštumas vidaus degimo variklio deginiais gali būti prognozuojamas vertinant srauto dinamines charakteristikas ir automobilių kieki gatvių tinkle, naudojant transporto srautų sutelktujjų parametrų matematinị modelį.

\section{Darbo rezultatų aprobavimas}

Disertacijos tema atspausdinti 7 moksliniai straipsniai: trys - Thomson ISI Web of Science žurnaluose su citavimo indeksu, vienas - Tarptautinių konferencijų recenzuotų darbų leidiniuose (ISI Proceedings), vienas recenzuojamoje tarptautinès konferencijos medžiagoje, du - kitose tarptautinių ir respublikinių konferencijų medžiagose.

Disertacijoje atliktų tyrimų rezultatai buvo paskelbti penkiose tarptautinėse mokslinèse konferencijose:

- tarptautineje konferencijoje „TRANSBALTICA 2012“ $2012 \mathrm{~m}$. Vilniuje;

- tarptautineje konferencijoje „TRANSBALTICA 2010“ $2010 \mathrm{~m}$. Vilniuje;

- 11-toji tarptautineje konferencijoje „Transport Means“ 2007 m. Kaune;

- 10-toji Lietuvos jaunųų mokslininkų konferencija „Mokslas - Lietuvos ateitis" $2007 \mathrm{~m}$. Vilniuje;

- 9-toji Lietuvos jaunųų mokslininkų konferencija „Mokslas - Lietuvos ateitis" $2006 \mathrm{~m}$. Vilniuje.

\section{Disertacijos struktūra}

Disertaciją sudaro ịvadas, keturi skyriai ir rezultatu apibendrinimas. Taip pat yra šeši priedai. Darbo apimtis yra 126 puslapiai, neskaitant priedų, tekste panaudotos 84 numeruotos formulès, 72 paveikslai ir 2 lentelès. Rašant disertaciją buvo naudoti 85 literatūros šaltiniai. 



\section{1}

\section{Mokslinès literatūros analizè. Transporto srautų matematiniai modeliai}

Automobilių transporto srautai labai skirtingai aprašomi matematiniais modeliais. Skirtingos matematinio uždavinio formuluotès leidžia gauti skirtingus modeliavimo rezultatus. Šiame skyriuje pateikiama detalesnè matematinių modelių apžvalga, daugiausiai dèmesio skiriant matematiniams kontinuumo transporto srautų modeliams.

\subsection{Diskretiniai transporto srautų matematiniai modeliai}

Modeliuojant transporto srautus (TS) ar sprendžiant praktinio pobūdžio TS uždavinius naudojami diskretiniai TS modeliai Herty et al. (2005). Jie sudaromi panaudojant sukauptą informaciją apie transporto srautus. Informacija nuolat kaupiama naudojant sistemas su detektoriais, kurie imontuoti kelio dangoje ar virš eismo juostos. Tokio tipo modeliai iprastai naudojami trumpalaikèms transporto srauto prognozėms pateikti. Pavyzdžiui, statistinis modelis ARIMA, apibendrintas tiesinis modelis. 
Statistika paremti modeliai naudoja apibendrintus TS parametrus Chowdhury et al. ( 2000), kurie buvo išmatuoti per tam tikrą laiko intervalą, ar naudoja transporto srauto parametro pasiskirstymo funkcijas. Taip pat statistiniai metodai reikalauja atmesti išmatuotų transporto srauto parametrų didžiausias ir mažiausias reikšmes.

Kaip analogas statistiniams metodams pateikiami stebejimais pagristi metodai, kurie naudoja Artifical Intelligence technologijas, kokybinius metodus (qualitative reasoning) Guan (2004). Tokių modelių pavyzdžiai: Bayesian ar Neuroninių tinklų pagrindu sudaryti modeliai Ho, Ioannou (1996), Markovo grandinių teorija paremti modeliai, fuzzy-neural metodu sudaryti modeliai Alnasur et al. (2006), Quddus et al. (2006), Liu et al. (2008) Detaliau Bayesian tinklu teorijos pagrindu sudarytas transporto srautu modelis pateiktas autorių McCrea, Moutari (2010) darbe. Statistiniai metodai neretai naudojami sprendžiant optimizavimo uždavinius ir ieškant būdų sumažinti prastovas važiuojant miesto sąlygomis.

Al-Deek, Emam (2006) patikimumo pasirenkant maršrutą klausimą sprendžia statistiniais metodai. Patikimumo, nuvykti laiku, svyravimo intervalą jie užrašo lygtimi:

$$
E\left(s_{i}\right)=E\left(x_{i}\right)-E\left(c_{i}\right)=\left[\bar{x}_{l}-\bar{c}_{l}\right],
$$

čia $\bar{x}_{l}$ - kelio apkrovimas imamas kaip poreikis patekti i kelio atkarpą; $\bar{c}_{l}-$ galimybė patekti $\mathfrak{i}$ kelio atkarpą; $s_{i}$ - tikslumas; tikslumo standartinis nuokrypis išreikštas išraiška:

$$
\sigma^{2}\left[s_{i}\right]=\sigma^{2}\left[x_{i}\right]+\sigma^{2}\left[c_{i}\right]-2 \cdot \rho \cdot \sigma\left[x_{i}\right] \cdot \sigma\left[c_{i}\right],
$$

čia $\sigma\left[x_{i}\right]$ ir $\sigma\left[c_{i}\right]$ poreikio ir galimybès patekti i kelio atkarpą standartiniai nuokrypiai; $\rho$-koreliacijos koeficientas tarp $\sigma\left[x_{i}\right]$ ir $\sigma\left[c_{i}\right]$

Nesèkmingos kelionès tikimybė užrašyta taip:

$$
\psi \geq \frac{\varepsilon_{i} \bar{c}_{l}-E\left(s_{i}\right)}{\sigma\left[s_{i}\right]}=1-\psi\left(\phi_{i}\right),
$$

čia $\psi\left(\phi_{i}\right)$ - normalinio skirstinio pasiskirstymo funkcija; $\phi_{i}-$ patikimumo indeksas, išreiškiamas per $\sigma\left[s_{i}\right]$.

Waldeer (2004) modeliavimui naudoja Markovo grandinių teoriją, statistiniais metodus aprašo chaoso procesus transporto sraute. Autorius, vertindamas priešais esančio ir ji sekančio automobilio padetị, greiti ir pagreiti, aprašo kintamojo funkciją. I kintamojo funkcijos pokyčio išraišką taip pat įtraukta Dirako funkcija, kuri su tikimybe $p$ aprašo pagreičio šuolị dydžiu $\varepsilon$. Automobilių srauto modelis aprašomas Fellerio - Kolmogorovo lygtimi. 
Angshuman (2004) disertacijoje plačiai nagrinejjami skirtingi matematiniai metodai automobilių eismo ivykiams nustatyti tam tikroje kelio atkarpoje. Detaliai testuojami keturi algoritmai ir nustatomas metodų patikimumas bei eismo įvykio nustatymo greitis kiekvienu metodu.

\subsection{Automobilių sekimo paskui automobilius matematiniai modeliai}

Kita didelè automobilių transporto srautų modeliu grupé yra automobilių sekimo paskui automobili matematiniai modeliai. Šie matematiniai modeliai detaliai aprašo automobilių tarpusavio sąveiką. Jų sudarymo principas paremtas tuo, kad automobiliai juda kolona ir šios kolonos priekyje važiuoja lèčiausias automobilis, kuris ir nulemia visos kolonos judejimo greitį. Vertinant atstumus tarp automobiliu atsižvelgiama ne tik $\mathfrak{i}$ automobilio matmenis, bet ir pasirenkamas saugus atstumas tarp automobilių. Matematiniuose modeliuose saugaus atstumo išraiška vertinama skirtingai. Su tokio tipo TS modeliais dirbo: Сильянов (1977), Al-nasur, Kachroo, (2006).

Xie, et al. (2009) naudodamiesi optimalaus greičio teorija modeliuoja mišrius transporto srautus, kuriuose dalyvauja motorinès ir nemotorinès TP.

Sekimo paskui lyderị matematinị modeli galima užrašyti tokia forma:

$$
\frac{d v_{n}}{d t}=\frac{a \cdot v_{n}}{l^{2}}\left(v_{n+1}-v_{n}\right),
$$

čia $\frac{a \cdot v_{n}}{l^{2}}$ - santykis ịvertina vairuotojo reakciją; $v_{n}$ ir $v_{n+1}$ - atitinkamai važiuojančio priekyje ir sekančio už jo automobilių greičiai, $l$ - atstumas tarp automobilių, $a$ - koeficientas.

Analogišką matematinị sekimo paskui lyderị modelị pateikia Mccartney (2003). Modelyje autorius naudoja dažnai daugelio autorių vartojamą matematinę išraišką:

$$
\frac{d^{2} x_{1}(t+T)}{d t^{2}}=\lambda\left[\frac{d x_{0}(t)}{d t}-\frac{d x_{1}(t)}{d t}\right],
$$

kuri užrašoma tokia forma:

$$
\frac{d^{2} x_{1}}{d t^{2}}+\beta \tau \frac{d x_{1}}{d t}+\beta x_{0}
$$

čia $x_{0}(t)$ ir $x_{1}(t)$ - priešais esančio automobilio ir kito už jo važiuojančio 
automobilio padètys laiko momentu $t$. $\lambda$ ir $\beta$ - lygčiu (1.5) ir (1.6) jautrumo koeficientai. Kuo koeficientai didesnysis, tuo staigesnè sekančio automobilio reakcija i pasikeitusią situaciją tarp automobilių. $T$ - vairuotojo reakcijos trukmè. $\tau$ - laiko tarpas, kuris reikalingas pasiekti priešais stovinti automobilį. Dydis $\tau$ dažniausiai imamas lygus $2 \mathrm{~s}$.

\subsection{Kontinuumo matematiniai modeliai}

Trečia ir didžiausia automobilių transporto srautų matematinių modelių apžvalgos dalis apima kontinuumo matematinius modelius. Šie matematiniai modeliai automobilių transporto srautą aprašo kaip vientisą terpę. Klasikiniai matematiniai modeliai sudaryti automobilių transporto srautams pritaikius dujų kinetinę teoriją, kuri paremta Boltsmano dujų judejjimo lygtimis arba hidrodinaminę teoriją, kuri paremta Novje-Stokso lygtimis aprašančiomis skysčio tekejjimą.

\subsubsection{Kinetinè teorija}

Dujų kinetinè teorija automobilių transporto srautams modeliuoti pirmą kartą panaudota Prigogine, Herman (1971) ir daugelio autorių cituota vèlesniuose moksliniuose straipsniuose. Prigogine, Herman (1971) suformuluotos teorijos apibendrinimas pateikiamas toliau tekste. Kai eismas gatvèse yra pakankamai mažas, galima teigti, jog kiekvieno automobilio vairuotojas nekomunikuoja su kitų automobilių vairuotojais. Tokiu atveju tampa teisinga lygybè:

$$
\frac{\partial f}{\partial t}+v \frac{\partial f}{\partial x}=0
$$

kuri rodo, jog automobilių skaičiaus pasikeitimas elementariame plote $d x d v(d x$ - elementarios kelio atkarpos ilgis, $d v$ - greičio pokytis) yra lygus skirtumui automobilių, kurie ịvažiuoja ị ši plotą ir kurie ji palieka. Śi lygybe parodo, kad greičio pasiskirstymo funkcija laiko momentu $t$ taške $x$ yra lygi greičio pasiskirstymo funkcijai laiko momentu $t=0$ taške $x-v t$.

Realiomis sąlygomis svarbus yra kitas atvejis, kai automobilis yra tankaus srauto dalyvis. Tada jo judejjimą įtakoja ne tik konkretaus automobilio vairuotojas, bet ir ji supančiu automobilių vairuotojai. Šioje vietoje įvedama vairuotojų populiacijos trokštama greičio pasiskirstymo funkcija $f_{0}(x, v, t)$. Dydis $f_{0}(x, v, t) d v d t$ rodo automobiliu, kuriu vairuotojai laiko momentu $t$ kelio intervale $d x$ juda greičių intervale tarp $v$ ir $v+d v$, skaičių. Pagal tai, koks vairuotojų pasiskirstymas yra kelio atkarpoje, galimi du relaksavimo i trokštamą greičio 
pasiskirstymo funkciją variantai: po tam tikro laiko vairuotojai grižžta ị norimą pasiskirstymo funkciją arba pasiekia norimą pasiskirstymo funkciją; dèl susidariusių trukdžių kelyje patenka i taip vadinamas „transporto spūstis“. Relaksavimo (grị̌imo ị pusiausvyra padèti) dèsnis transporto srautų sistemoje užrašomas diferencialine lygtimi:

$$
\frac{\partial f}{\partial t}=-\frac{f-f_{0}}{T},
$$

čia $T$ - prisitaikymo laikas. Automobilių transporto srautų lygti Tampère (2004) užrašo šia priklausomybe:

$$
\frac{\partial f}{\partial t}+v \frac{\partial f}{\partial x}=-\frac{f-f_{0}}{T},
$$

Šioje lygtyje neivertinama vairuotojų tarpusavio sąveika. Joje tik nurodoma, kad po tam tikro laiko $T$ bendra srauto greičio pasiskirstymo funkcija $f$ bus apytiksliai lygi $f_{0}\left(f \approx f_{0}\right)$, todèl, siekiant ivertinti vairuotoju tarpusavio sąveiką, dešinè (1.9) lygties pusè suskaidoma ị realią ir kintamą dalis:

$$
\frac{\partial f}{\partial t}+v \frac{\partial f}{\partial x}=\left(\frac{\partial f}{\partial t}\right)_{r e l}+\left(\frac{\partial f}{\partial t}\right)_{\mathrm{int}}
$$

Realioji (1.10) lygties dešinès pusès dalis lygi:

$$
\left(\frac{\partial f}{\partial t}\right)_{\text {rel }}=-\frac{f-f_{0}}{T}
$$

Kintama (1.10) lygties dalis lygi:

$$
\left(\frac{\partial f_{i}}{\partial t}\right)_{\mathrm{int}}=\sum_{j}\left(\Gamma_{i j}^{(+)}-\Gamma_{i j}^{(-)}\right)(1-P)=f_{i}(x, v, t) c(x, t)\left[\bar{v}(x, t)-v_{i}\right](1-P),
$$

čia $P$ - tikimybè, kad vairuotojas galès atlikti lenkimo manevrą; $\Gamma_{i j}^{(-)} d x d v d t-$ aprašo automobilių skaičių, kuris atimamas iš $d x d v$ kaip nekontaktuojantis su $j$ tipo automobiliais laiko momentu $d t$. Dydis $\Gamma_{i j}^{(+)} d x d v d t$ - aprašo automobiliu kieki kuris pridedamas prie $d x d v$ kaip turintis kontaktą su $j$ tipo automobiliais laiko momentu $d t$. Tarkime $i$ tipo automobilis kelio atkarpoje $x$ važiuoja greičiu $v_{i}$. Praejus laiko tarpui $d t$ galima tikimybe jog automobilis $i$ kontaktuos su automobiliu $j$ kurio greitis $v_{j}<v_{i}$. Šių automobilių suma intervale $\left(v_{i}-v_{j}\right)>0$ yra lygi $\Gamma_{i j}^{(-)}$. Norint nustatyti charakteristiką $\Gamma_{i j}^{(+)}$imame, kad $x$ kelio atkarpoje, $i$ 
tipo automobilis važiuoja greičiu $v_{i}$ ir po laiko tarpo $d t$ yra galimybè, kad automobilis $i$ kontaktuos su automobiliu $j$, kurio greitis $v_{j}>v_{i}$. Tada automobilio $j$ greitis aprašomas $\left(v_{j}-v_{i}\right)>0$. Visų šių automobilių, judančių greičiu $v_{j}$, suma yra lygi $\Gamma_{i j}^{(+)}$. Galutinai (1.12) lygtis užrašoma taip:

$$
\frac{\partial f}{\partial t}+v \frac{\partial f}{\partial x}=-\frac{f-f_{0}}{T}+(1-P) c(\bar{v}-v) f .
$$

Ši teorija vėlesniuose autorių darbuose buvo nemažai kritikuota. Neatitikimus tarp matematinio modelio ir fizinių eksperimentų duomenų vienas pirmujjų pastebejo Pavery-Fontna. Jis pasiūlè naudoti automobilių pageidaujamo greičio išraišką, tai yra toki greitị, kuriuo važiuojantis automobilis artètų matematiniame modelyje. Jeigu prieš ji važiuojantys automobiliai važiuoja didesniais greičiais ir jų koncentracija priešais esančioje kelio atkarpoje yra maža, automobilis gali igauti pageidautiną greitị. Jeigu priešais esantys automobiliai važiuoja mažesniu nei pageidautinas greičiu, tai automobilis seka paskui tokiu pat greičiu, kol situacija nepasikeičia. Šią teoriją taikè: Illner et al. (2002), Tampère (2004), Herty et al. (2005), Burger et al. (2007), Bonzani (2007).

Ngoduy et al. (2009) straipsnyje nurodomi būdai, kaip galima pakeisti automobiliu greitị, jeigu priešais esančioje kelio atkarpoje susidaro spūstys ir TS greitis ženkliai sulèteja. Automobiliai „bendrauja“ signalų pagalba. Matematinis modelis sudarytas pasinaudojus dujų kinetine teorije papildomai įvedant funkciją, kuri iš anksto leistų sumažinti greitị eismo juostoje prieš spūstį.

\subsubsection{Hidrodinaminè teorija}

(LWR) teorijoje, tiesioje kelio atkarpoje, ar jos modifikacijose diferencialine lygtimi aprašomas transporto priemonių intensyvumo pokytis kažkokioje baigtineje eismo juostos atkarpoje ir kaip pagrindinis parametras naudojama transporto srauto koncentracija, nagrinejamoje eismo juostos atkarpoje. Automobilių transporto srauto greičio parametrui nustatyti iprastai naudojama greičio pasiskirstymo funkcija, kuri bendru atveju priklauso nuo automobilių srauto koncentracijos nagrinejjamame eismo juostos atkarpos intervale. Su šia teorija dirbo Shvetsov (2003), Velasco ir Saavedra (2008), Colombo et al. (2007), Gasser (2003), Knowles (2008).

Lighthill-Whitham ir Richards (LWR) teorijos pagrindą sudaro du svarbiausi parametrai: tam tikros stambios kelio atkarpos srauto koncentracija $k(x, t)$, automobilių kiekis ilgio vienete, ir srautas $Q(x, t)$ duotu laiko momentu $t$, o srautą aprašanti lygtis - pirmos eilès diferencialinè lygtis. Srauto vientisumas aprašomas lygtimi: 


$$
\frac{\partial c(x, t)}{\partial t}+\frac{\partial Q(x, t)}{\partial x}=\sum_{i=1}^{Q_{i m}} \alpha_{i}\left(x-x_{i}, t\right)-\sum_{i=1}^{Q_{m}} \beta_{i}\left(x-x_{j}, t\right) .
$$

Dešinèje lygybès pusèje aprašoma srauto iejjimo ir išèjimo i $i$-tają kelio atkarpą vertè (vertès pokytis). Šios išraiškos užrašomos šia forma:

$$
\begin{aligned}
& \alpha_{i}\left(x-x_{i}, t\right)=\alpha_{i}^{0}(t) \phi_{i}\left(x-x_{i}\right), \\
& \beta_{j}\left(x-x_{j}, t\right)=b_{j}^{0}(t) \phi_{j}\left(x-x_{j}\right),
\end{aligned}
$$

čia išraiškos $\phi_{j}\left(x-x_{j}\right)$ ir $\phi_{i}\left(x-x_{i}\right)$ aprašo srauto intensyvumo svyravimus, o koeficientai $b_{j}^{0}(t)$ ir $\alpha_{i}^{0}(t)$ momentinius srauto intensyvumo pokyčius. Išraiška (1.14) negali būti sprendžiama kaip atskira lygtis, nes ji turi du nežinomuosius $k(x, t)$ ir $Q(x, t)$. Ši lygtis gali būti sprendžiama tik tada, kai nežinomieji yra tarpusavyje susiję ir vienas nežinomasis nustatomas naudojantis kitu nežinomuoju. Autoriai pasiūlè prielaidą, pagal kurią automobilių srautas išreiškiamas kaip funkcija nuo koncentracijos. Tačiau tokia išraiška negali būti nustatoma iš srauto vientisumo lygties, nes srauto vientisumo lygtis turi du nežinomuosius. Tam papildomai reikalingi arba empiriniai duomenys, arba $\mathfrak{i}$ teoriją turi būti įvedamos papildomos sąlygos. Be to srauto priklausomybè nuo koncentracijos turi tenkinti fundamentalią diagramą (srauto intensyvumo priklausomybè nuo koncentracijos arba greičio pasiskirstymo nuo koncentracijos išraiška). Naudodamiesi tokia prielaida Lighthill ir Whitham srauto vientisumo lygti užrašè šia forma:

$$
\frac{\partial c(x, t)}{\partial t}+\frac{\partial c(x, t)}{\partial x}\left[v(x, t)+c(x, t) \frac{d v}{d c}\right]=\frac{\partial c(x, t)}{\partial t}+v_{g} \frac{\partial c(x, t)}{\partial x}=0,
$$

čia automobilių srautas $Q(x, t)$ buvo išreikštas per transporto srauto koncentraciją $k(x, t)$ ir srauto judejjimo greiti $v(x, t)$. Taipogi transporto srauto srauto greitis yra priklausomas nuo koncentracijos taške $x$. Išraiška $v_{g}$ užrašoma tokia forma:

$$
v_{g}=\frac{d Q}{d k}=v(k)+k \frac{d v(k)}{d k} .
$$

Šios išraiškos sprendinys užrašomas tokia apibendrinta forma:

$$
k(x, t)=F\left(x-v_{g} t\right),
$$

čia $F$ - funkcija, priklausanti nuo kelio koordinatès ir TS greičio. Tada išraišką (1.16) galima užrašyti šia forma:

$$
k\left[\frac{\partial v}{\partial t}+v \frac{\partial v}{\partial x}\right]=-D \frac{\partial k}{\partial x}+\mu \frac{\partial^{2} k}{\partial x^{2}}+\frac{k}{t_{d}}\left[v_{\text {safe }}(k)-v\right],
$$


Sutrumpintai LWR lygti galima užrašyti šia forma:

$$
\frac{\partial \rho}{\partial t}+\frac{\partial\left(\rho V_{e}(\rho)\right)}{\partial x}=0
$$

čia $\rho$ - transporto srauto koncentracija; $V_{e}$ - automobilių srauto vidutinis greitis priklausantis nuo koncentracijos.

Ši modeli patobulino Payne ir užrašè tokia išraiška Lei, Yu (2009):

$$
\left\{\begin{array}{c}
\frac{\partial \rho}{\partial t}+\frac{\partial(\rho v)}{\partial x}=0 \\
\frac{\partial v}{\partial t}+v \frac{\partial v}{\partial x}=\frac{V_{e}(\rho)-v}{t}+\frac{k}{\rho \tau} \frac{\partial \rho}{\partial x} .
\end{array}\right.
$$

Ivedama relaksacijos laiko sąvoką $\tau$ ir koeficientas $k=\frac{V_{e}^{\prime}(\rho)}{2}$. Payne pakoreguotame modelyje buvo netinkamai įvertintas greitis, nes jis galèjo būti neigiamas. Autoriai Garavello, Piccoli (2006) pateiktame modelyje be kita ko nurodo, jog uždavinio patikimumas ir stabilumas gali labai skirtis tiesios kelio atkarpos viduryje ir galuose, kur ịvedamos kraštinès uždavinio sąlygos, nes šiuose taškuose gali nesutapti informacija, kuri gaunama iš šalia esančio mazgo. Pagrindinę lygčių sistemą autoriai siūlo užrašyti tokia forma:

$$
\left\{\begin{array}{c}
\partial_{t} \rho+\partial_{x}\left(y-\rho^{\gamma+1}\right)=0 \\
\partial_{t} y+\partial x\left(\frac{y^{2}}{\rho}-y \rho^{y}\right)=0
\end{array}\right.
$$

čia $\gamma>0 ; \rho$ - automobilių srauto koncentracija; $v$ - automobilių srauto greitis; $y=\rho v+\rho^{\gamma+1}-$ judesio impulsas. Sistemos tikrinès reikšmès yra sekančios: $\lambda_{1}=\frac{\gamma}{\rho}-(\gamma+1) \rho^{\gamma} ; \lambda_{2}=\frac{\gamma}{\rho}-\rho^{\gamma}$. Sistema yra stabili, kai tenkinama sąlyga:

$$
\frac{\rho^{\gamma+1}-\rho_{0}^{\gamma+1}}{\rho_{-}-\rho_{0}}>\rho_{0}^{\gamma},
$$

čia „,0“ taškas - charakteristiku susikirtimo taškas; ,„-“ taškas esantis prieš nulinị tašką.

Chronopoulos, Johnson (1998) nurodo sąlygas ir būdus, kada ir kokiuose metoduose naudoti greičio pasiskirstymo funkciją arba fundamentalią diagramą, o kuriuose naudoti eksperimentinių matavimų duomenis.

Siebel, Mauser (2005) transporto srautus aprašo dviejų lygčių sistema. Pristatomas modelis vadinamas (ARG) modeliu. Jeigu relaksacijos laikas $T=0$, 
šis uždavinys supaprastèja iki klasikinio LWR modelio. Pagrindinè modelio lygčių sistema užrašytos šia forma:

$$
\left\{\begin{array}{c}
\frac{\partial \rho}{\partial t}+v \frac{\partial \rho}{\partial x}+\rho \frac{\partial \rho}{\partial x}=0 \\
\frac{\partial v}{\partial t}+\left(v+\rho u^{\prime}(\rho)\right) \frac{\partial \rho}{\partial x}=\frac{u(\rho)-v}{T}
\end{array}\right.
$$

čia $u(\rho)$ - greičio pasiskirstymo nuo koncentracijos funkcija; $u(\rho)<0$, kai $0<\rho<\rho_{\max }$. Uždavinio tikrinès reikšmès:

$$
\begin{gathered}
\lambda_{1}=-i k\left(u+\rho_{0} u^{\prime}\right), \\
\lambda_{2}=-\frac{1}{T}-i k u .
\end{gathered}
$$

Šiame ir daugelyje prieš tai minètų straipsnių greičio pasiskirstymo funkcija užrašome tokia funkcija:

$$
V_{e}(\rho)=u(\rho)=u_{\max }\left(1-\left(\frac{\rho}{\rho_{\max }}\right)^{n_{1}}\right)^{n_{2}} .
$$

Laipsnio rodikliai imami lygūs: $n_{1}=0,35$, o $n_{2}=1 . u_{\max }-$ didžiausias leistinas greitis.

Uždavinio sprendimui autoriai naudoja skirtingus matematinius metodus Zhang et al. (2009), Chalons ir Goatin (2008) matematines išraiškas sprendžia Godunovo metodu.

Yu et al. (2010) sprendžia aukštesnès eiles Payne tipo uždavinị. Sprendžiant skaitiniais metodais uždavinys užrašomas per tris taškus: „,-1“, ,i“, ,i+1“. Uždavinys sprendžiamas baigtinių skirtumų metodu

Li et al. (2009) transporto srautus modeliuoja naudodami LWR teoriją, tačiau i lygtis ịvedamas vèlinimo laikas, per kurị transporto priemonès pasiekia optimalų greitị. Darbe taip pat pateikiama stabilumo sąlyga, kuri išreiškiama per vèlinimo laiką.

Chronopoulos ir Johnson (1998) matematines išraiškas siūlo spręsti Lax metodu.

Kerner ir Klenov (2006) nagrinèja mikroskopinius transporto srautu modelius ir išskiria du nesikartojančių laike transporto srautų modelius. Vienai grupei šie autoriai priskiria modelius, kurie vertina vairuotojo reakcijos vèlinimo laiką bei automobilio lètejimo ir greitejjimo pagreičius. Kitai grupei priskiriami modeliai, kuriais aprašomi transporto srautų pokyčiai esant nestabilioms uždavinio sąlygoms. Uždavinio sprendiniai gaunami iš viendimensių kreivių, 
kaip pavyzdžiui srauto - koncentracijos plokštuma. Šie metodai paremti fundamentalia diagrama (srauto ir koncentracijos diagrama). Autoriai kritikuoja metodus, paremtus fundamentalia diagrama, nes šie metodai nepaaiškina srauto trūkio taško (zonos, kurioje esant tai pačiai koncentracijai galimi skirtingi transporto srauto greičiai). Patys straipsnio autoriai pristato savo modeli, kuriame išskiriamos trys transporto srauto kitimo fazès: neapriboto srauto fazè, sinchronizuoto srauto fazè ir lètai judanti spūstis.

\subsection{Taikomojo pobūdžio darbai}

Nagrinejjant mokslinius darbus pastebima, jog daug dèmesio modeliuojant kelių ar gatvių sankryžas skiriama optimizavimo uždaviniams Horn (2006). Matematiškai aprašant transporto srautus sankryžose naudojami tiek mikroskopiniai, tiek makroskopiniai transporto srautų matematiniai modeliai. Ragauskaitè et al. (2009) modeliuoja nereguliuojamas sankryžas. Jų straipsnyje pateikiamos prielaidos: kada automobilis gali kirsti sankryžą, kada susidaro automobilių eilès. Gowri, Sivanandan (2008) pristato sankryžos modeli, kai sukama i kaire. Mikalauskas (2010) straipsnyje pateikia Simulink paketu sumodeliuotą TS valdymo algoritmą. Herty et al. (2007) matematiškai modeliuodami transporto srautu susikirtimus naudoja klasikini kontinuumo matematini modeli, dar vadinama Lithtihill - Whitham - Richardsaon`o (LWR) modeliu. Sudarant sankryžų matematini modelị preciziškai užduodamos kraštinès įeinančių ir išeinančių eismo juostų sąlygos. Eismo srautai išskaidomi ị kelis alternatyvius srautus naudojant laike kintantị koeficientą, kurio kitimo ribos $0 \div 1$, o ieinančių ir išeinančių srautų suma lygi 0 . Darbe autoriai siekia optimizuoti transporto srautų paskirstymą visame tinkle. Uždavinys sprendžiamas greičiausio nuolydžio metodu. Autoriai sprendžia laiko sugaištamo stovint keliose sankryžose minimizavimo uždavinį. Šio uždavinio tikslas minimizuoti gatvių tinkle sugaištamo laiko vertę pasirenkant alternatyvius maršruto variantus, kai priešingu atveju dèl susidariusių eilių tektų sugaišti nemažai laiko. Panašius uždavinius sprendžia Wie et al. (2008), Xie et al. (2009), nagrinejja eismo srautus sankryžose, kuriose kaip eismo dalyviai dalyvauja tiek motorizuotos, tiek bemotorès transporto priemonès. Matematinio modelio pagrindą sudaro optimalaus greičio ir sekimo paskui lyderị matematiniai modeliai, kuriuose vertinami skirtingi transporto priemoniu greičiai. Vertinamas transporto priemonių uždelsimas reguliuojamose ir nereguliuojamose sankryžose. Gatviu tinklas modeliuojamas naudojant grafų teoriją. Autoriai nagrinèja posūkio ị kairę (transporto priemonès juda kaire kelio puse) ypatumus. Autoriai nagrinejja atvejus kuomet posūkio metu susidaro mažesnio pralaidumo rankové ir visas, norintis pasukti i kairę, transporto 
priemonių srautas turi laukti savo eilès. Kaip vienas iš parametrų išskiriamas susidariusios rankovès ilgis. Daug autorių eismo srautus tiria pasinaudodami GIS paketai Jiang et al. 2002; Khalesian et al. 2009). Taip pat šie darbai tampriai siejasi su GPS ir kitomis pažangiomis kelio paieškos ar kitomis sistemomis.

Modeliuojant sankryžų ar gatvių tinklus dažniausiai sprendžiami srauto parametrų optimizavimo uždaviniai. Pagrindinès tokių uždavinių kryptis yra: sutrumpinti laiką, kurị automobiliai sugaišta važiuodami iš taško A i tašką $B$, parinkti optimalų maršrutą pagal iš anksto užduotas atrankos sąlygas. Daugelis tokių uždavinių pritaikomi transporto srautų reguliavimui, žalios bangos kūrimui, navigacinèms sistemos ar kitiems kasdieniniams poreikiams tenkinti. Al-Deek (2006) arba Ni et al. (2006) darbuose sprendžia optimizavimo uždavinị ir ieško būdų, kaip iš vienos miesto vietos nuvykti ị kitą su mažiausiu vẻlavimu.

Kaip atskiras srautu modeliavimo atvejis išskiriamas transporto srautų modeliavimas siekiant tirti, prognozuoti aplinkos užterštumą. Tokie modeliai gali būti pritaikomi tiek miesto gatvių tinkle, tiek magistraliniuose ar regioniniuose keliuose. Lietuvoje tokio tipo darbai buvo pristatyti Bazaro (2008) ir Ilgakojytės (2002), taip pat Ilgakojytės-Bazarienès ir Marškaičio (2005) disertacijose ar straipsniuose.

Didelè dalis opių problemų kyla eksploatuojant automobilius. Čia pagrindinès problemos, kurias tenka spręsti tiek inžinieriams tiek mokslininkams, yra užterštumo mažinimas ir energijos taupymas. Taupant energiją automobiliai tampa draugiškesni aplinkai. İvairias automobilių sukeliamas problemas aptaria Makaras et al. (2011). Autoriai aptaria automobiliu dinamiką sraute, kuro suvartojimą ir faktorius, kurie ịtakoja kuro suvartojimą, aplinkos poveikị automobilių dinamikai, paliečia vairuotojo modelị ir vairavimo stilius. Wang et al. (2008) pateikia skirtingus kuro suvartojimo ir variklių emisijos matavimo metodus ir naudingumo rodiklius. Tanczos ir Torok (2007) tiria klimato svyravimo pokyčius ir energijos suvartojimą Vengrijoje. Straipsnyje pateikiama klimato ir $\mathrm{CO}_{2}$ kaitos dinamika, kuro suvartojimas Vengrijos respublikoje. Taip pat pateikiamos $\mathrm{CO}_{2}$ emisijos: iš $1 \mathrm{~mol}$ dyzelino $(198 \mathrm{~g})$ susidaro14 mol arba $616 \mathrm{~g} \mathrm{CO}_{2}$ ir iš $1 \mathrm{~mol}$ (114 g) benzino susidaro $8 \mathrm{~mol}$ arba $352 \mathrm{~g} \mathrm{CO}_{2}$. Janulevičius et al. (2010) pateikia kuro suvartojimo nustatymo metodiką vertinant variklio galią ir specifinį kuro suvartojimą. Wu ir Liu (2011) pristato metodiką kuro kiekio suvartojimui apskaičiuoti vertinant tokius kriterijus kaip aerodinaminis ir riedejjimo pasipriešinimas. Kuro suvartojimo modelis sukurtas neuroninių tinklų teorijos pagrindu. Smit et al. (2008) pateikia ir apibendrina tris emisijos modelius, kuriuose skirtingai ịvertinama spūsčių ịtaka motorinių transporto priemonių emisijai, ir taip pat pateikia rodiklius transporto spūstims nustatyti. Straipsnyje taip pat pateikiami spūsčiu nustatymo metodai. Jovic ir Doric (2010) pasinaudodami programiniu paketu PTV, visi modeliuoja 
transporto srautus miesto gatvių tinkle ir, atsižvelgdami ì sumodeliuoto transporto srauto intensyvumą, pateikia vidaus degimo variklių deginių emisijas. Jakimavičius ir Burinskienè (2010) nagrinejja automobilių srautų optimizavimo metodus ir ju pritaikymo galimybes informuojant eismo dalyvius apie padèti mieste, o straipsnyje Jakimavičius ir Burinskienè (2009) pateikiama Vilniaus miesto mikrorajonų reitingavimo sistema pasitelkiant ekspertu metodus ir nurodomi labiausiai transporto priemonemis apkrauti miesto mikrorajonai. Kliukas et al. (2008) tiria sunkiuju transporto priemonių sukeliamų vibracijų itaką statiniams, siekiant apsaugoti kultūrines vertybes Vilniaus mieste. Kaip pavojingi išskiriami 1,3 ir $10,8 \mathrm{~Hz}$ dažniai. Žiliūte et al. (2010) tiria transporto srautų intensyvumą ir pateikia matavimų duomenis intensyviausiose Vilniaus miesto gatvèse. Sivilevičius (2011) tiria transporto sistemos elementų tarpusavio sąveiką vertinant transporto srauto elementus. Šliupas (2006) pristato metodus transporto srautams prognozuoti. Bellucci ir Cipriani (2010) nustato, kokią įtaką TS matavimo prietaisams daro atmosferiniai veiksniai.

Pateiktų mokslinių darbų apžvalga parodo transporto srautų matematinių modelių praktinio pritaikymo galimybes ir išryškina mokslo šakas kurioms šie modeliai yra reikalingi sprendžiant praktinio pobūdžio mokslines, inžinerines, aplinkosaugines problemas.

\subsection{Pirmo skyriaus išvados ir darbo uždavinių formulavimas}

Atlikus matematinių modelių analizę pastebima, kad aprašant transporto srautus naudojant automobilių sekimo paskui automobilius matematinius modelius ir siekiant gauti tikslesni rezultatą, reikia aprašyti kiekvieną eismo dalyvi ir jam priskirti individualias charakteristikas. Tai nèra praktiška, jeigu tiriamas didelis gatvių tinklas. Kontinuumo modeliuose transporto srautas aprašomas kaip vientisas kūnas ir lyginant su diskretiniais modeliais naudojant ši modelị transporto srautus galima aprašyti visame gatvių tinkle. Tuo tarpu, aprašant transporto srautą diskretiniais metodais, modeliui sudaryti naudojami tam tikruose gatvių tinklo pjūviuose išmatuoti srauto parametrai. Šiuose gatvių tinklo pjūviuose išmatuoti srauto parametrai priskiriami visam tinklui. Metodas yra gana griozdiškas, reikalaujantis apdoroti didžiulius išmatuotos informacijos kiekius.

Analizuojant literatūrą pastebèta:

1. Tikimybiniuose transporto srautų modeliuose parametrams aprašyti naudojam skirstiniai. Didžiausios ir mažiausios transporto srauto parametrų reikšmès yra atmetamos. 
2. Kontinuumo modeliuose transporto srautas nagrinejjamas kaip vientisas kūnas, tačiau naudojami diskretizuoti transporto srauto parametrai.

3. Modeliuojant transporto srautus kontinuumo metodais reikia naudoti fundamentaliąją kreivę arba eksperimentiškai išmatuotus duomenis.

4. Automobilių sekimo paskui automobilius matematiniai modeliai tiksliau aprašo automobilių sąveiką ir vairuoto reakciją i padètị kelyje.

Siekiant supaprastinti sistemą, kuri tiria transporto srautus neprarandant tikslumo numatoma:

1. Pasiūlyti idejją ir sukurti naują matematinị modelị, kurị naudojant būtų galima pakankamai tiksliai tirti transporto srautus.

2. Sukurtą ir tradicinị kontinuumo modelius palyginti tarpusavyje.

3. Natūrinio eksperimento metu gautus transporto srauto parametrus panaudoti sukurto modelio patikrinimui.

4. Parodyti, kaip sukurtą matematini modeli panaudoti sprendžiant taikomojo pobūdžio uždavinius. 



\section{2}

\section{Sukurto transporto srauto matematinio modelio tyrimas}

Šio skyriaus medžiaga buvo publikuota straipsniuose: Junevičius et al. (2011, 2007), Junevičius, Bogdevičius $(2009,2008,2007)$.

\subsection{Modelio sudarymo prielaidos}

Toliau pateituose poskyriuose aprašytos prielaidos, kurios taikomos transporto srautuc modeliams sudaryti. Skyriuose pateiktos prielaidos, apibendrinimai, supaprastinimai.

\subsubsection{Prielaidos tiesiai gatvès eismo juostai aprašyti}

Aprašant transporto srautus, kaip pagrindinè, naudojama eismo juostos sąvoka. Imama prielaida jog automobiliai negali išvažiuoti ị priešpriešinio eismo juostą, todèl kelias suskaidomas i atskiras eismo juostas ir dvipusio eismo keliai matematiniame modelyje aprašomi kaip atskiri, vienos krypties, keliai su viena ar keliomis eismo juostomis. Modelyje eismo juostos ruožas imamas kaip baigtinio ilgio tiesé, kuri sudalinama $\mathfrak{i}$ vienodo ilgio atkarpas kurių ilgis $L_{i, i+1}$ (2.1 pav.). Kelio atkarpos parametrai (transporto srauto greitis, transporto srauto 
koncentracija ar srauto intensyvumas) sutelkiami atkarpu galiniuose taškuose. Taškas, kuris jungia dvi greta esančias atkarpas turi bendrą tašką priklausantị abiem atkarpom. Pirmas ir paskutinis nagrinejjamos eismo juostos taškai yra atitinkamai duomenų, kraštinèms sąlygoms, ịvedimo taškai. Transporto srauto parametrų didžiausios ir mažiausios reikšmès kiekvienai kelio atkarpai užduodamos atskirai ir gali būti skirtingos. Minimalios transporto srauto greičio ir koncentracijos reikšmès paprastai imamos lygios nuliui. Didžiausia galima greičio reikšmė nustatoma remiantis stebejjimais. Didžiausia leistina transporto srauto koncentracijos reikšmė gali būti skaičiuojama pagal formulę:

$$
k=\frac{n}{L_{i, i+1}},
$$

čia $n$ - automobilių skaičius, vnt; $L_{i, i+1}-$ kelio atkarpos ilgis, m.

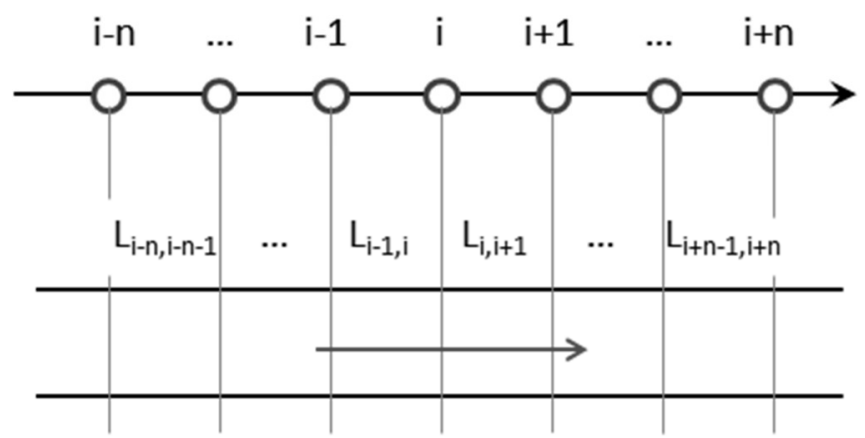

2.1 pav. Transporto srauto modelis tiesioje eismo juostos atkarpoje

Fig. 2.1. Transport flow model on a straight segment of a traffic lane

Modeliuojant imama prielaida jog kelio atkarpos persipildyti negali. Jeigu automobilių kiekis kelio atkarpoje pasiekia viršutinę koncentracijos ribą i šią atkarpą daugiau automobilių patekti negali. Jeigu kelio atkarpa užsipildo, o automobilių srauto verte išlieka nepakitusi, didèja arba nežymiai mažeja, tačiau šis sumažejimas yra nepakankamas, ir priekyje esanti kelio atkarpa išlieka perpildyta - automobiliai ima kauptis sekančioje kelio atkarpoje, kuri eina iškarto po užpildytos kelio atkarpos.

Automobilių srauto greitis, taip pat, yra apribotas. Kiekviena kelio atkarpa turi savo leistiną didžiausią greiti, kuris gali būti skirtingas kiekvienoje atkarpoje.

Jeigu kelias turi kelias vienos krypties eismo juostas, modeliuojant priimama prielaida, kad yra viena eismo juosta, kurios koncentracijos parametrai proporcingai padidinami. Ši prielaida leidžia apjungti kelias vienos krypties 
eismo juostas i vieną ir modelis tampa paprastesniu, kadangi nereikia vertinti transporto priemonių migravimo iš vienos eismo juostos i kitą.

Modelyje suskaidytos eismo juostos atkarpos numeruojamos $L_{i-1, i}, L_{i+1, i}$, kai $i=1-n,-$ kelio taško numeris. (2.2 pav.). Šio segmento galuose esantys taškai sutapatinti su šalia esančių segmentų galiniais taškais. Pirmas elemento taškas prilyginamas paskutiniam prieš ji einančio elemento taškui, o paskutinis elemento taškas prilyginamas pirmam po jo einančio elemento taškui. Kraštiniuose elementuose, pirmame pirmo elemento taške ir paskutiniame paskutinio kelio elemento taške įvedamos uždavinio kraštinès sąlygos.

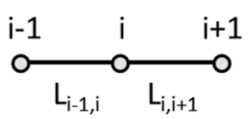

a)

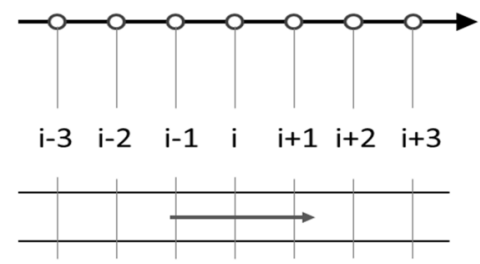

b)

2.2 pav. Tiesaus kelio elementų aprašymas:

a - du elementai $L_{i-1, i}, L_{i+1, i}$ sujungti taške $i$; b - iš kelių elementų, sujungtų taškuose $1-7$, sudaryta tiesi gatvès atkarpa

Fig. 2.2. A description of elements of a straight road. a) two elements $L_{i-1, i}$ and $L_{i+1, i}$, are connected at point $i$; b) a straight road segment drawn from several road segments connected at points $1-7$

Tokie kraštinių sąlygų taškai (2.2 pav.) yra 1 ir 7. Šiuose taškuose visą modeliavimo laiko tarpą yra žinoma įeinanti ir išeinanti ị sistemos informacija. Tokiu būdu ị sistemą dažniausiai ịvedama srauto verté, kuri visą modeliavimo laiką gali būti pastovi arba kisti pagal tam tikrą iš anksto žinomą dèsnį.

\subsubsection{Prielaidose eismo juostų susikirtimams aprašyti}

Aprašant eismo juostų susikirtimus sankryžose tiesios eismo juostos elementams sujungti tarpusavyje būtina suderinti kraštines sąlygas.

Sankryža imama kaip atskiras transporto srautu sistemos elementas, kuri sudaro mazgas su viena ar keliomis įeinančiomis eismo juostomis ir viena ar keliomis išeinančiomis eismo juostomis. Sankryžos modelyje (2.3 pav.) ieinančių i sankryžą ir išeinančių iš sankryžos eismo juostų kryptys parodytos rodyklèmis.

Tiesios atkarpos 1, 2, 3 modeliuojamos taip kaip aprašyta 2.1 .1 skyrelyje, o eismo juostų susikirtimo taškas turi šias kraštines sąlygas: schemai a 


$$
\begin{gathered}
p_{1}(k v)_{D, 1}+p_{2}(k v)_{D, 2}-p_{3}(k v)_{D, 3}+p_{4} Q_{0 u t}(t)-p_{5} Q_{i n}(t)=0, \\
\sum_{i=1}^{2} p_{i}=1 . \sum_{i=3}^{5} p_{i}=1 .
\end{gathered}
$$

schemai b

$$
\begin{gathered}
p_{1}(k v)_{D, 1}-p_{2}(k v)_{D, 2}-p_{3}(k v)_{D, 3}+p_{4} Q_{0 u t}(t)-p_{5} Q_{i n}(t)=0 ; \\
p_{1}=0 \ldots 1, \sum_{i=2}^{5} p_{i}=1 .
\end{gathered}
$$

Transporto srauto parametrai $k$ ir $v$ esantys lygtyse (2.2) ir (2.4) apskaičiuojami tolesniuose skyriuose pateiktomis matematinemis išraiškomis, o tikimybès $p$ gali būti nustatomos tiek, kaip pastovios reikšmès konstantos, tiek kaip laike kintančios funkcijos, tiek kaip funkcijos priklausančios nuo transporto srauto parametrų pirmame už susikirtimo esančiame elemente.

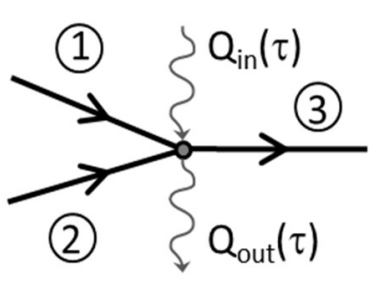

a)

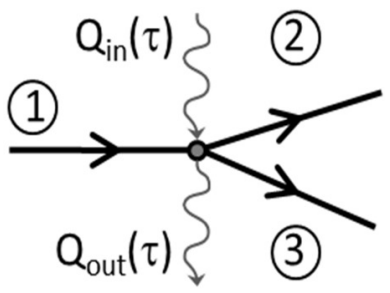

b)

2.3 pav. Eismo juostų susikirtimo schemos:

a) eismo juostų susiliejimas; $b$ ) eismo juostos išsidalinimas

Fig. 2.3. Traffic flow intersection diagram: a) interflow of traffic lines;

b) embranchment of traffic lines

Eismo juostos su sankryža jungiamos tarpiniuose taškuose, kurie yra bendri tiek sankryžos, tiek eismo juostos elementui. Iš sankryžos išeinančios eismo juostos pirmasis mazgas yra prilyginamas sankryžos išèjimo mazgui (2.4 pav. mazgai $\left.\mathrm{II}_{1}, \mathrm{III}_{1}, \mathrm{IV}_{1}, \mathrm{~V}_{1}\right)$. Paskutinis eismo juostos mazgas - prilyginamas sankryžos iejjimo mazgui (2.4 pav. mazgai $\mathrm{I}_{\mathrm{n}}, \mathrm{II}_{\mathrm{n}}, \mathrm{III}_{\mathrm{n}}$ ). Sankryžos tarpusavyje sujungiamos tiesiomis kelio atkarpomis ir gaunamas eismo juostų (arba gatvių) tinklas. Vieno kelio priešingų krypčių eismo juostos gali būti tarpusavyje sujungiamos tik sankryžoje, kai jau nurodytu būdu sujungiama įeinanti ir išeinanti eismo juosta, kurios priklauso tam pačiam keliui, bet yra priešingu krypčių. 
2.5 ir 2.6 paveiksluose pateikiamas detalesnis sankryžos modelio aprašymas. Kaip pavyzdys pateikiami trišalès sankryžos schema ir modelis, kuriuose yra trys įeinantys ir trys išeinantys eismo srautai atitinkamai $Q_{\text {in } I I, I I I}^{I r} Q_{\text {out }}^{I, I I, I I I}$, o taip pat kiekvienas ieinantis eismo srautas gali būti išskaidomas $\mathfrak{i} \mathrm{du}$ išeinančius srautus $Q_{i n}^{I} \Rightarrow Q_{\text {in }}^{I\left(I I_{\text {out }}\right)}+Q_{\text {in }}^{I\left(I I I_{\text {out }}\right)}$. Šie išskaidyti srautai gali jungtis tarpusavy i viena bendrą išeinantị srautą $Q_{o u t}^{I} \Rightarrow Q_{i n}^{I I\left(I_{\text {out }}\right)}+Q_{i n}^{I I I\left(I_{\text {out }}\right)}$. Atitinkamai išskaidoma ir kitų srautų informacija.

kelias II
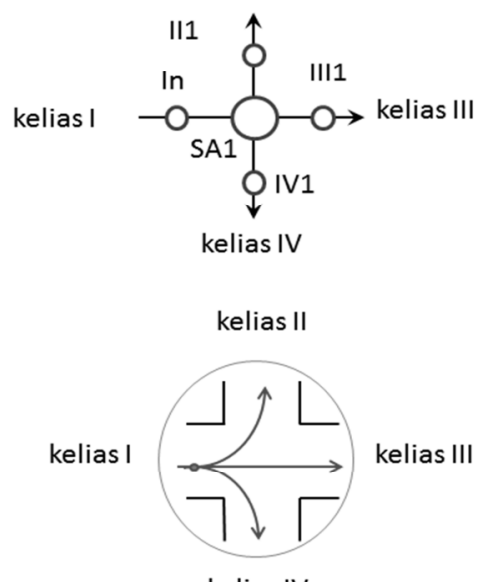

kelias IV
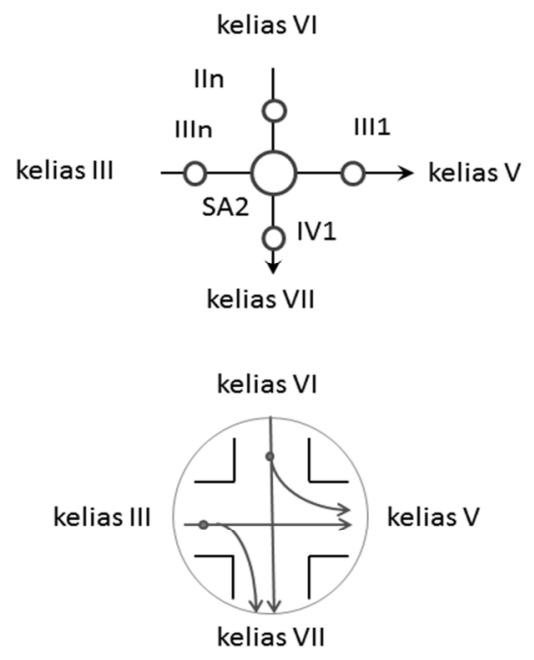

2.4 pav. Eismo srautų sankirtų modeliai

Fig. 2.4. Models of traffic intersections

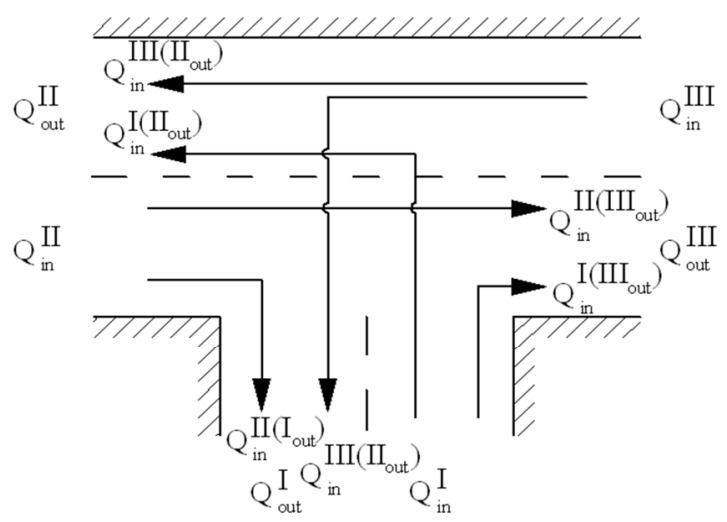

2.5 pav. Trišalès sankryžos schema

Fig. 2.5. Scheme of crossroad from three incoming and three outgoing roads 
Ivedama laike kintanti valdymo funkcija - vienu metu i sankryžą įvažiuoti galima tik iš vienos eismo juostos. Tada transporto priemonių srautas gali pasiskirstyti tarp dviejų, iš sankryžos išeinančių, eismo juostų.

Siekiant išvengti sankryžos ar jos prieigu perpildymo, sudarant modeli, ivedamos kelios pataisos:

- srautas taškuose aprašomas išraiška $Q=k \cdot v$;

- koncentracijos didejjimas iejjimo taškuose $i=1 \ldots 6$ ir išejjimo taškuose $i=7 \ldots 8$ negali būti didesnis nei maksimali galima koncentracija $k_{i} \leq k_{i, \max }$;

- jeigu ieinančio taško koncentracija didesnè nei išeinančio, tai įeinančiąjame taške koncentracija kaupiasi kol pasiekia maksimalią reikšmę $k_{i, \max }$;

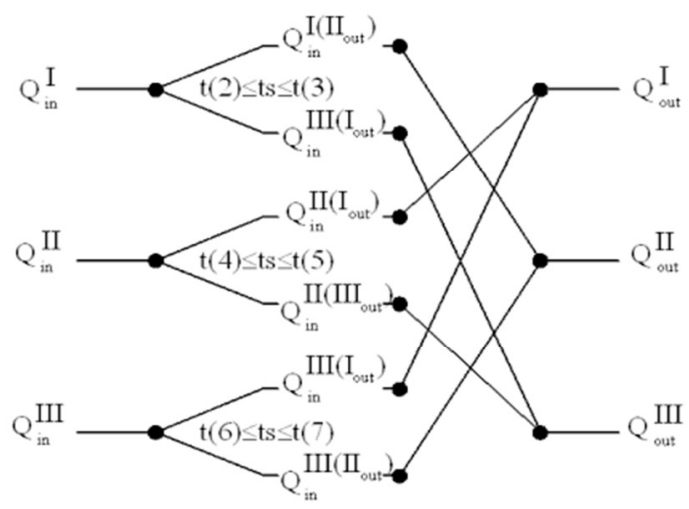

2.6 pav. Trišalès sankryžos modelis

Fig. 2.6. Modell of crossroad from three incoming and three outgoing roads

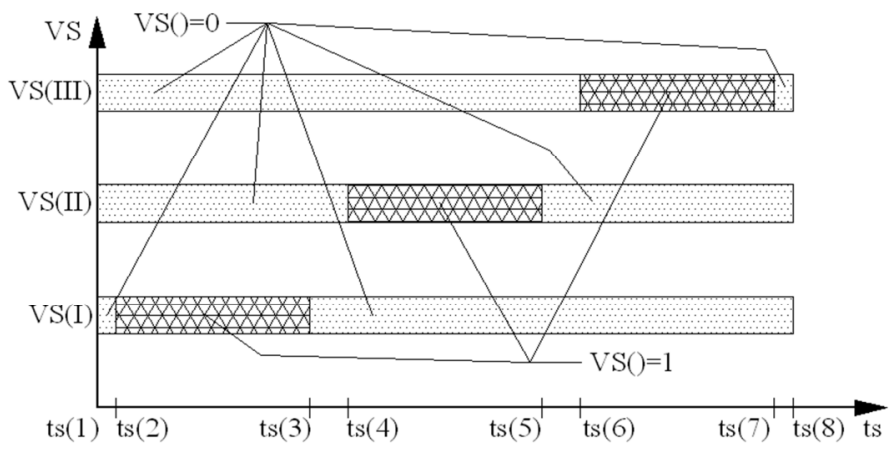

2.7 pav. Sankryžos signalų valdymo algoritmas

Fig. 2.7. Algorithm of control signals at crossroad 
Tikrinant perpildymo sąlygą koncentracijos pokytis įeinančiame taške apskaičiuojamas pagal formulę: $\Delta k=k_{\text {out }}-k_{\text {in }}$, kai $k_{\text {in }} \leq k_{\text {out }}$. Tuomet, kai $\Delta k \neq 0$ ieinančiame sankryžos taške, - koncentracijos vertès kaupiamos taškuose esančiuose prieš įjjimo ị sankryžą tašką.

Sankryžos transporto srautų valdymo signalo pasiskirstymo laike grafikas pateiktas 2.7. paveiksle. Visoms î sankryžą ieinančioms eismo juostoms priskiriama signalo verte $V S=0$. Tuomet kai iš atitinkamos juostos automobiliai gali įvažiuoti ị sankryžą priskiriama signalo vertė $V S=1$. Vienu metu eismas galimas tik vienai ieinančiai eismo juostai. Modeliuojant sudètingesnio valdymo sankryžas signalų algoritmas koduojamas analogiškai.

\subsection{Klasikinès matematinès išraiškos, aprašančios kontinuumo modelius}

\subsubsection{Dujų kinetinè transporto srautu teorija}

Iš literatūros apžvalgos (Tampère, 2004), žinoma, jog modeliuojant transporto srautus naudojant dujų kinetinę teoriją, transporto srautams aprašyti naudojamos transporto srautų koncentracijos ir transporto srauto greičio kitimo lygtys.

$$
\begin{gathered}
\frac{\partial k}{\partial t}+v \frac{\partial k}{\partial x}+k \frac{\partial v}{\partial x}=0 \\
k \frac{\partial v}{\partial t}+k v \frac{\partial v}{\partial x}+\sigma \frac{\partial k}{\partial x}=k\left(\frac{d v}{d t}\right) v-k \frac{\partial \sigma}{\partial x}
\end{gathered}
$$

čia $k$ - transporto srauto koncentracija; $v$ - transporto srauto greitis; $t-$ laikas; $x$-koordinate; $\sigma$-transporto srauto greičio nuokrypis.

Norint šias lygtis spręsti skaitiniais metodais, reikia atlikti tam tikrus pakeitimus. Lygtys gali būti sprendžiamos charakteristikų metodu, todèl siekiant pritaikyti jas šiam metodui atliekami šie pakeitimai.

Transporto srautus aprašančios lygtys užrašomos matricine forma:

$$
\left.\left.[A]\left\{\frac{\partial\{u\}}{\partial t}\right\}+[B]\right\} \frac{\partial\{u\}}{\partial x}\right\}=\{f\},
$$

čia $\{u\}=\{k, v\}-$ kintamujų $k$ (transporto srauto koncentracija) ir $v$ (transporto srauto greitis) vektorius, $[A]$ ir $[B]$ matricos, kurių išraiškos yra:

$$
[A]=\left[\begin{array}{ll}
1 & 0 \\
0 & k
\end{array}\right],[B]=\left[\begin{array}{cc}
v & k \\
k v & \sigma
\end{array}\right],
$$


$\{f\}$ - išoriniu jègų vektorius, kurio išraiška aprašoma:

$$
\{f\}=\left\{k\left\langle\frac{d v}{d t}\right\rangle_{v}^{0}-k \frac{\partial \sigma}{\partial x}\right\} .
$$

Jeigu matricos (2.11) determinantas kiekviename $\Gamma$ kreivès taške nelygus nuliui, tada visos išvestinès nustatomos vienareikšmiškai. Jeigu išilgai $\Gamma$ kreivès determinantas lygus nuliui, tada iš prielaidos, kad egzistuoja (2.8) sistemos sprendinys, gauname, $\mathrm{kad}$ išvestinès $\partial\{u\} / \partial t$ ir $\partial\{u\} / \partial x$ nustatomos nevienareikšmiškai. Šiuo atveju $\Gamma$ kreivè vadinama charakteristika Bogdevičius Prentkovskis (2003)

$$
[B] d t-[A] d x .
$$

Prilyginę matricos (2.11) determinantą nuliui, gauname lygtị:

$$
\left|[B]-[A] \frac{d x}{d t}\right|=0
$$

iš kurios galima surasti $d x / d t$ išvestinę, kuri nustato charakteristikos kryptį. Išsprendus (2.12) lygtị, gaunamos tikrinès reikšmès $-d x / d t$ :

$$
\frac{d x}{d t}=V \pm \sigma
$$

Jeigu ši lygtis turi $n$ skirtingų realių šaknų $d x / d t=\lambda_{i} \quad(i=1,2, \ldots, n)$, tai pradinè diferencialinių lygčių sistema vadinama hiperbolinio tipo. Charakteristikos liestinès posvyris $\lambda_{l}$ priklauso ne tik nuo koordinačių, bet ir nuo $\{u\}$ sprendinio. Todèl plokštumoje $t, x$ nubraižyti charakteristikas galima tik konkrečiam diferencialinių lygčių sistemos sprendimui. Jeigu (2.8) sistema yra hiperbolinio tipo, tada (2.11) matricos rangas lygus $n-1$. Kitą vertus, jeigu egzistuoja sprendinys, tada matricos (2.14) rangos lygus $n-1$.

$$
([B] d t-[A] d x,\{f\} d t-[A] d\{u\})
$$

Prilyginę (2.14) matricos determinantą nuliui, kuris sudarytas iš (2.11) matricos $n-1$ stulpeliu ir vektoriaus $\{f\} d t-[A] d\{u\}$, t.y.

$$
|[B] d t-[A] d x,\{f\} d t-[A] d\{u\}|=0
$$

Gauname lygti, kuri vadinama suderinamumo sąlyga arba diferencialine sąsaja. Charakteristikos yra linijos, kurios atskiria sritis su mažais sužadinimais. Lygtis 
(2.12) vadinama charakteristikų krypčių lygtimi, o išraiška (2.13) yra šios sistemos sprendinys.

Irašę $[A]$ ir $[B]$ matricų bei $\{f\}$ vektoriaus išraiškas i (2.15) lygtị ir ją išsprendę, gauname dvi lygtis, kurios vadinamos $C^{+}$ir $C^{-}$charakteristikomis. Suderinamumo sąlygos ant charakteristikų lygios:

$$
\begin{aligned}
& C^{+}: \frac{d V}{d t}+\frac{\sigma}{k} \frac{d k}{d t}-g_{1}=0 \\
& C^{-}: \frac{d V}{d t}-\frac{\sigma}{k} \frac{d k}{d t}-g_{2}=0 .
\end{aligned}
$$

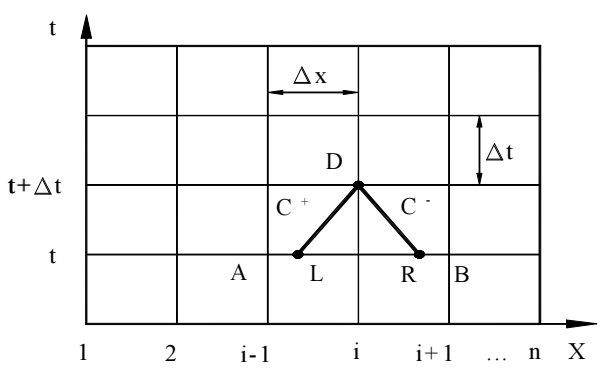

2.8 pav. Transporto srauto parametrų nustatymo schema taške $D$

Fig. 2.8. Sheme of determination of traffic flow parameters at point $D$

Visas kelio atkarpos ilgis suskaidomas $\mathfrak{i}$ elementus, kuriu ilgis $\Delta x$ Laiko momentu $t+\Delta t$ uždavinio nežinomieji - srauto koncentracija $k$ ir transporto srauto greitis $v$ nustatomi iš jų žinomų reikšmių laiko momentu $t$ (2.8 pav.). Lygčių sistemoje (2.16) ir (2.17) pakeitę diferencialus baigtiniais skirtumais, gauname dviejų netiesinių algebrinių lygčių sistemą Bogdevičius, Prentkovskis (2003):

$$
\begin{aligned}
C^{+}: & \Phi_{1}=v_{D}-v_{L}+\frac{1}{2}\left[\left(\frac{\sigma}{k}\right)_{L}+\left(\frac{\sigma}{k}\right)_{D}\right] \times \\
& \times\left(k_{D}-k_{D}\right)-\frac{\Delta t}{2}\left(g_{D}+g_{L}\right) ; \\
C^{-}: & \Phi_{2}=v_{D}-v_{R}-\frac{1}{2}\left[\left(\frac{\sigma}{k}\right)_{R}+\left(\frac{\sigma}{k}\right)_{D}\right] \times \\
\quad & \left(k_{D}-k_{R}\right)-\frac{\Delta t}{2}\left(g_{D}+g_{R}\right),
\end{aligned}
$$

čia $g_{1}, g_{2}-$ transporto srautu greičio pokytis aprašomas išraiškomis: 


$$
\begin{aligned}
& g_{1}=\left\langle\frac{d v}{d t}\right\rangle_{v}-\frac{\partial \sigma}{\partial x} \\
& g_{2}=\left\langle\frac{d v}{d t}\right\rangle_{v}-\frac{\partial \sigma}{\partial x} .
\end{aligned}
$$

čia $L, R, D$ - indeksai, kuriais pažymèti kintamieji ir funkcijos atitinkamuose patikslintuose taškuose, o simboliu $i$ pažymèti charakteristikų tinklelio mazgu taškai.

Netiesinè algebrinių lygčių sistema (2.20) ir (2.21) sprendžiama Niutono metodu (B priedas).

\subsubsection{Dujų kinetinès transporto srautų teorijos lygčių sprendimo stabilumas}

Sprendinio stabilumui laiduoti, sprendžiant uždavinį charakteristikų metodu, būtina tenkinti Kuranto sąlygą:

$$
\Delta t\left|v+\sigma^{2}\right| \leq \Delta x .
$$

Per taškus $L$ ir $D$ praeina $C^{+}$charakteristika, kurios lygtis yra:

$$
\frac{d x}{d t}=v+\sigma^{2}
$$

čia $\sigma^{2}$ - transporto srauto greičio dispersija, $(\mathrm{m} / \mathrm{s})^{2} ; \mathrm{v}$ - transporto srauto greitis, $\mathrm{m} / \mathrm{s}$. Integravus (2.33) išraišką tarp taškų $L$ ir $D$, gauname taško $L, x$-ają koordinatę:

$$
x_{L}=x_{D}-\left(v_{L}+a_{L}\right) \Delta t .
$$

Tarp taškų $A$ ir $C$ esančiame taške $\mathrm{L}$ greitis ir slègis nustatomi taikant tiesines interpoliacines formules:

$$
\frac{x_{D}-x_{L}}{\Delta x}=\frac{v_{C}-v_{l}}{v_{C}-v_{A}} .
$$

Irašę (2.24) išraišką i (2.25) išraiškas, gauname dviejų netiesinių algebrinių lygčių sistemą su nežinomaisiais $k_{L}$ ir $v_{L}$ :

$$
v_{L}=\frac{v_{C}-\theta\left(v_{C}-v_{A}\right) a_{L}}{1+\theta\left(v_{C}-v_{A}\right)} ;
$$




$$
k_{L}=k_{C}-\left(k_{C}-k_{A}\right)\left(v_{L}-a_{L}\right) \theta,
$$

čia $\theta=\Delta t / \Delta x$. Netiesinių algebrinių lygčių sistema (2.26) ir (2.27) sprendžiama Niutono metodu.

Analogiškai nustatomos kintamųjų reikšmès taške $R$. Šiuo atveju gauname dviejų netiesinių algebrinių lygčių sistemą su nežinomaisiais $k_{R}$ ir $v_{R}$ :

$$
\begin{gathered}
v_{R}=\frac{\theta\left(v_{C}-v_{B}\right) a_{R}+v_{C}}{1+\theta\left(v_{C}-v_{B}\right)} ; \\
k_{R}=k_{C}-\left(k_{C}-k_{B}\right)\left(v_{R}-a_{R}\right) \theta .
\end{gathered}
$$

Netiesinių algebrinių lygčių sistema (2.28) ir (2.29) sprendžiama Niutono metodu, (B priedas).

\subsection{Teorinis sutelktųjų parametrų automobilių transporto srautų modelis}

\subsubsection{Naujo matematinio modelio idèjos apibendrinimas. Matematinių išraiškų formulavimas}

Aprašant automobilių transporto srautus siūlomas naujas metodas, kuriame yra vertinami trys vienas paskui kitą einantys mazgai (2.9 pav.). Automobilio srauto parametrų pokyčio lygtys užrašomos mazgui $i$, bet kartu yra vertinami transporto srauto parametrai dar dviejuose mazguose: $i-1$ ir $i+1$.

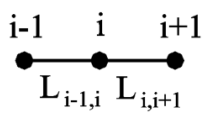

2.9 pav. Schema, automobilių transporto srautams aprašyti mazge $i$

Fig. 2.9. A scheme for deriving traffic flow values at each traffic line point $i$

Netiesinès dinamikos kurse, nagrinejjant populiacijų gausejjimą ar aprašant kai kuriuos kitus matematinius modelius dažnai naudojama Verhulsto pasiūlyta matematinè išraiška gyvūnų populiacijų dinamikai aprašyti Pyragas (2003).

$$
\dot{N}=r N\left(1-\frac{N}{K}\right),
$$

čia $N$ - nagrinejjamos populiacijos individų skaičius, $K$ - maksimali individų reikšmė nuo kurios populiacijos individų gausejjimo skaičius igauna neigiamą 
greiti. Kaip ir populiacijų gausèjimo modelyje taip ir transporto srautų modelyje neigiama automobiliu reikšmè transporto juostoje prasmès neturi. Darant šią prielaidą galima užrašyti transporto priemoniu pokytị transporto juostos elemente, kurio ilgis $L_{i-1, i}$ ar $L_{i+1, i}$. Kadangi šis segmentas iš abiejų galų yra apribotas greta esančių elementų, kuriose koncentracijos pokyti galima aprašyti analogiškomis formulèmis. Automobiliai visoje kelio atkarpoje juda nustatyta kryptimi ir iš vieno baigtinio ilgio elemento pereina $\mathfrak{i}$ kitą baigtinio ilgio elementą, todèl norint susieti koncentracijų pokyčius gretimuose eismo juostos segmentuose lygtis (2.30) pritaikoma transporto srautams ir užrašoma tokia forma:

$$
\dot{k}_{i}=r\left(1-\frac{k_{i}}{k_{\max , i}}\right) k_{\tau, i-1}-r\left(1-\frac{k_{i+1}}{k_{\max , i}}\right) k_{\tau, i},
$$

čia $k_{\tau}$ - užduodamas koncentracijos uždelsimas.

Laiko momentas $\tau_{i}=\frac{L_{i}}{v_{i}}$ apskaičiuojamas kiekviename $i$-tajame elemente ivertinus transporto srauto greiti $i$-tajame elemente. Šiame modelyje imama prielaida jog visame eismo juostos elemente transporto srauto greitis yra vienodas. Koeficientai $r$ - funkcijos priklausančios nuo koncentracijos elemente. Pateiktoje matematineje išraiškoje $i$-tajame elemente nustatoma koncentracijos verte, tačiau vertinamos ir prieš ji esančio elemento koncentracijos, bei po jo sekančio elemento koncentracijos. Tam, kad koncentracijos pokytis žaibiškai nebūtų perduodamas iš vieno elemento ị kitą ịvedamas uždelsimo laikas $\tau$, kuris kinta priklausomai nuo srauto parametrų. Matematine išraiška (2.31) aprašomas transporto srauto pokytis visuose eismo juostos elementuose. Nagrinejjamo srauto galuose ịvedamos kraštinès sąlygos su žinomomis koncentracijomis.

Bendru atveju visa sistema užrašoma tokia išraiška:

$$
\left\{\begin{array}{l}
\dot{k}_{1}=s_{1}-r\left(1-\frac{k_{2}}{k_{\max , 1}}\right) k_{\tau, 1} ; \\
\dot{k}_{i}=r\left(1-\frac{k_{i}}{k_{\max , i}}\right) k_{\tau, i-1}-r\left(1-\frac{k_{i+1}}{k_{\max , i}}\right) k_{\tau, i}, \text { kai } i=2 \ldots n-1 ; \\
\dot{k}_{n}=r\left(1-\frac{k_{n}}{k_{\max , n}}\right) k_{\tau, n-1}-s_{2} .
\end{array}\right.
$$

čia $s_{1}$ ir $s_{2}$ atitinkamai įeinantis ir išeinantis koncentracijos pokytis kraštiniuose taškuose. 
Siekiant išvengti transporto srauto persipildymo elemente $L_{i-1, i}$ ar $L_{i+1, i}$ ivedami tokie apribojimai:

$$
\left\{\begin{array}{l}
\text { kai } k_{i} \geq k_{\max } \text {, tai } k_{i}=k_{\max } \\
\text { kitais atvejais, } k_{i}=k_{i} .
\end{array}\right.
$$

Transporto srauto intensyvumas sudarytas iš dviejų parametrų $k$ ir $v$, o jo vertè skaičiuojama pagal formulę $q=k v$, todèl norint pilnai aprašyti transporto srauto intensyvumą reikia nusistatyti ir greičio pokyčio išrašką. Vadovaujantis literatūros šaltiniu Prigogine, Herman (1971) imama tokia greičio pasiskirstymo nuo koncentracijos išraišką:

$$
\dot{v}_{i}=\lambda \ln \left(\frac{k_{\mathrm{max}, i}}{k_{i}}\right), \quad k a i \quad i=1 \ldots n,
$$

čia $\lambda$ - funkcija priklausanti nuo transporto srauto parametrų, $\mathrm{m} / \mathrm{s} . k_{\max }, k-$ atitinkamai didžiausia leistina ir duotuoju laiko momentu esanti transporto srauto koncentracija, auto/m.

Kaip matyti iš matematinių išraiškų koncentracijos reikšmei artejant prie 0 greičio funkcijos reikšmè artejja prie $+\infty$. Praktiškai tokio pokyčio negali būti, todèl siekiant išvengti srauto greičio artèjimo prie $+\infty$ būtina apriboti apatinę TS koncentracijos reikšmę bei viršutinę TS srauto greičio reikšmę. Toks apribojimas nèra geras, nes modeliuojant sankryžas transporto srautas yra pristabdomas ir už sankryžos stebimas išretejjimas, kadangi iš priekyje esančio elemento transporto priemonès išvažiuoja, o i elementą neįvažiuoja. Koncentracijos reikšmè arteja prie 0 , o tuo tarpu teorinis greitis arteja prie begalybės ir atidarius sankryžą pradiniu laiko momentu bus stebimas staigus greičio padidejimas. Realiomis sąlygomis toks padidejjimas nèra galimas, nes reikalingas pereinamas laikotarpis transporto srauto būsenai pakisti.

Siekiant išvengti išvardintų transporto srauto nestabilumų transporto srauto formuluotès užrašomos patobulinta forma:

$$
\begin{aligned}
& \dot{k}_{i}=p_{i n, i}(t) \cdot r_{k_{i}, \text { in }, i} \cdot\left(1-\frac{k_{i}(t)}{k_{\max , i}}\right) \cdot\left(\frac{q_{i-1}\left(t-\tau_{i-1}\right)}{q_{\max , i-1}}\right) \cdot k_{i}(t)- \\
& -p_{\text {out }, i}(t) \cdot r_{k_{i}, \text { out }, i} \cdot\left(1-\frac{k_{i+1}(t)}{k_{\max , i+1}}\right) \cdot\left(\frac{q_{i}(t)}{q_{\max , i}}\right) \cdot k_{i}(t) ;
\end{aligned}
$$

čia paprastumo dèlei lygtyse esantys parametrai aiškinami nenaudojant indeksų $i . k$ ir $v$-ieškomi transporto srautu parametrai: transporto srauto koncentracija ir 
TS greitis; $k_{\max }$ - didžiausias galim TS koncentracija kelio atkarpoje, auto/m; $v_{\max }-$ didžiausias galimas TS greitis elemente, $\mathrm{m} / \mathrm{s}$;

$$
\begin{aligned}
& \dot{v}_{i}=p_{i n, i}(t) \cdot r_{v_{i}, i n, i} \cdot\left(\frac{v_{i-1}\left(t-\tau_{i-1, i}\right)}{L_{i-1, i}}\right) \cdot\left(1-\frac{k_{i}(t)}{k_{\max , i}}\right) \cdot v_{i}(t)+ \\
& +f_{i}\left(k_{i+1, i}\right)-p_{\text {out }, i}(t) \cdot r_{v_{i}, \text { out }} \cdot\left(\frac{1}{2} \frac{v_{i}(t)+v_{i+1}(t)}{L_{i+1, i}}\right) \times \\
& \times\left(1-\frac{k_{i+1}(t)}{k_{\text {max }, i+1}}\right)^{m_{1}} \cdot v_{i}(t)-\left(\frac{v_{i}(t)}{v_{\text {max }, i}}\right) \cdot e^{\left[\gamma_{3}\left(\frac{k_{i}(t)}{k_{\text {maxi }}}\right)^{m_{2}}\right] \cdot\left(\frac{v_{i}(t)}{v_{\text {max }}}\right)},
\end{aligned}
$$

čia $L_{i-1, i}$ arba $L_{i+1, i}$ - diskretizuotos kelio atkaros ilgis, $\mathrm{m}$; $\tau$ - laiko intervalas reikalingas transporto srautui nueiti kelio atkarpą, kurios ilgis lygus $L_{i-1, i}$ arba $L_{i+1, i}, \mathrm{~s} ; \mathrm{m}_{1}, \mathrm{~m}_{2}, \gamma$ - konstantos; $q$ - transporto srauto intensyvumas, auto/s; $q_{\max }$ - didžiausias galimas srauto intensyvumas, auto/s; $r_{k, i n}, r_{k, \text { out }}-$ funkcijos reikšmè ivedanti pataisą srauto koncentracijos pokyčio išraiškai. $r_{\mathrm{v}, \text { in }}, r_{\mathrm{v}, \text { out }}-$ funkcijos reikšmės i̇vedančios pataisą srauto greičio pokyčio išraiškai. Funkcijas $r$ priklauso nuo koncentracijos ir nuo greičio verčių, o taip pat šios funkcijos gali turèti skirtingas reikšmes TS srautui ieinant i elementą ir ji paliekant $p_{\text {in }}(t)$ ir $p_{\text {out }}(t)$ - srauto patekimo i priešais esančią atkarpą tikimybè. Funkcijų $p_{\text {in }}(t)$, $p_{\text {out }}(t)$ reikšmès kinta laike priklausomai nuo TS koncentracijos ir srauto greičio reikšmių pokyčio arba gali būti ịvedamos kaip valdymo funkcijos; $f_{i}\left(k_{i+1, i}\right)-$ funkcija priklausanti nuo nežinomojo parametro $k$. Ši funkcija aprašo kelio atkarpos elemento, esančio prieš mazgą $i$, būklę, t. y. nurodo kiek intensyviai yra apkrauta ši eismo juostos atkarpa.

$$
f_{i}=\left\{\begin{array}{c}
e^{\gamma_{2}\left(1-\frac{\varepsilon_{i+1}}{\varepsilon_{i}}\right) \varepsilon_{i} \operatorname{sign}\left(p_{\text {outi }}(t)\right) \operatorname{sign}\left(1-\frac{\varepsilon_{i+1}}{\varepsilon_{i}}\right)}, \text { kai } \varepsilon_{i}>\varepsilon_{i+1} \text { ir } \varepsilon_{i}>0 ; \\
0, \text { kitais atvejais }, \\
\varepsilon_{i}=\frac{k_{i}}{k_{\text {max }, i}} .
\end{array}\right.
$$

Gautos srauto parametrų pokyčių laike funkcijos turi tokius privalumus lyginant su (2.32) ir (2.34) lygtimis:

- abi parametrų funkcijos kinta laike ir viena kitą įtakoja;

- ivvesti patikslinti empiriniai koeficientai $r$, kurie sušvelnina staigius nežinomų parametru verčių šuolius;

- funkcijos leidžia koncentracijos reikšmei igauti 0-nę reikšmę ir funkcijos neartejja prie $\infty$; 
- įvertinamas atstumas tarp dviejų gretimų kelio taškų

- ivvertinamas vélinimas, t. y. vertinamas laiko tarpas reikalingas srauto dalyviams patekti iš vieno kelio taško ị šalia esantị kita kelio tašką

Lygčių sistemos (2.35), (2.36) nariai suteikia pataisas ieškomiems srauto greičio ir koncentracijos parametrams.

Lygties (2.35) narys $1-\frac{k_{i}(t)}{k_{\max , i}}$ aprašo transporto srauto koncentracijos kitimo greiti mazge $i$. Lygties narys $1-\frac{k_{i+1}(t)}{k_{\max , i+1}}$ aprašo transporto srauto koncentracijos kitimo greiti mazge $i+1$, o taip pat augant transporto srauto koncentracijai eismo juostos atkarpoje esančioje ị prieki nuo mazgo $i$, transporto srauto judejjimo kryptim, šio nario vertè artejja prie nulio (elemento užpildymas arteja prie didžiausios galimos koncentracijos atkarpoje). Tokiu būdu sukuriamas apribojimas, kuris neleidžia persipildyti eismo juostos atkarpos elementui. Be to, transporto srauto koncentracijai taškuose $i$ ir $i+1$ artejant prie vertès $k_{\max }$ koncentracijos pokyčio greitis mažejja.

Lygties (2.35) narys $\frac{q_{i-1}\left(t-\tau_{i-1}\right)}{q_{\max , i-1}}$ aprašo transporto srauto būklę atkarpoje prieš mazgą $i$, transporto srauto judejjimo kryptim. Šis narys aprašo srauto koncentracijos prieaugli arba sumažejimą $i$-tajame mazge priklausomai nuo srauto intensyvumo eismo juostos atkarpoje iki taško $i$. Taip pat yra vertinamas laiko intervalas $\tau_{i-1}$ per kurị srautas iš vieno mazgo nukeliauja iki kito mazgo. Šis vèlinimas leidžia tiksliau aprašyti srauto judejjimą iš vieno mazgo ị kitą tais atvejais, kai atstumas tarp mazgų santykinai didelis, o srauto judejimo greitis santykinai mažas. Tokia situacija kyla kai eismo juosta sudalinta ị ilgas atkarpas, o srauto juodejjimo greitis priartèja prie $0 \mathrm{~m} / \mathrm{s}$ tačiau nèra lygus 0 . Vèlavimo laikas tuo didesnis kuo ilgesnis atstumas tarp mazgų ir kuo mažesnis srauto judejimo greitis atkarpoje.

Lygties (2.36) narys $\left(\frac{v_{i-1}\left(t-\tau_{i-1, i}\right)}{L_{i-1, i}}\right) \cdot v_{i}(t)$ aprašo transporto srauto pagreiti mazge $i+1$ ir jo itaką srauto greičiui mazge $i$, tuo tarpu narys $\left(\frac{1}{2} \frac{v_{i}(t)+v_{i+1}(t)}{L_{i+1, i}}\right) \cdot v_{i}(t)$ aprašo vidutinị transporto srauto pagreitị tarp mazgu $i$ ir $i+1$. Pastarasis narys taip pat vertina srauto būklę mazge einančiame po mazgo $i$ srauto judèjimo kryptimi. Jeigu transporto srauto greitis $i+1$ mažejja, tai mažèja greitis ir mazge $i$ ir atvirkščiai didèjant greičiui mazge $i+1$ didejja greitis ir mazge $i$. 
Narys $\left(1-\frac{k_{i+1}(t)}{k_{\max , i+1}}\right)^{m_{1}}$ aprašo transporto srauto pagreičio pokyti tarp mazgu $i$ ir $i+1$. Jeigu priešais esančioje eismo juostos atkarpoje automobilių koncentracija maža, koeficiento reikšmè artejja prie vieneto, kai koncentracija didelè - prie 0 . Taigi didejjant koncentracijai priešais einančioje kelio atkarpoje automobilių srauto greitis kelio atkarpoje $i$ mažejja.

Lygties (2.36) narys $1-\frac{k_{i}(t)}{k_{\max , i}}$ neleidžia sistemai persipildyti mazge $i$. Artejant srauto koncentracijos vertei prie $k_{\max }$ minèto nario vertè arteja prie 0 .

Narys $\left(\frac{v_{i}(t)}{v_{\max , i}}\right) \cdot e^{\left[\gamma_{3}\left(\frac{k_{i}(t)}{k_{\max , i}}\right)^{m_{2}}\right] \cdot\left(\frac{v_{i}(t)}{v_{\max , i}}\right)}$ ivvertina transporto priemonių skaičių mazge $i$ ir tiesiogiai ịtakoja koncentracijos reikšmę mazge $i$.

Automobilių skaičius eismo juostos atkarpoje apskaičiuojamas pagal formulę:

$$
N_{e}=\int_{x_{i}}^{x_{i}} k(x) d x,
$$

čia $x_{\mathrm{i}}$ ir $x_{\mathrm{j}}$ - eismo juostos atkarpos kraštiniai mazgai; $k(x)$ - transporto srauto koncentracija eismo juostos atkarpoje. Automobilių kiekio pokytis eismo juostos atkarpoje aprašomas išraiška:

$$
N_{i}(t+\Delta t)=N_{i}(t)+\int_{t_{i}}^{\Delta t+t_{i}} q_{i}(t) d t
$$

čia $q(t)$ - automobilių srauto intensyvumas eismo juostos atkarpoje $i$.

\subsubsection{Sukurto metodo pritaikymas transporto srautams modeliuoti sankryžose}

Šiame skyrelyje apžvelgiamas matematinių sankryžų modelių sudarymas ir valdymo komandų perdavimas i matematini modelį. Lygtys iš kurių sudarytas matematinis modelis ir prielaidos šiems modeliams sudaryti pristatytos 2.1-2.3 skyriuose.

2.2 ir 2.3 skyriuose aprašyti kelio elementai tarpusavyje gali būti jungiami ir i sudetingesnes sankryžas, kaip pavyzdžiui, 2.10 paveiksle pateiktos sankryžos.

Kraštinès sąlygos tokio tipo sankryžose, kiekvienam keliui su viena ieinančia ir viena išeinančia eismo juosta, gali būti aprašomos sekančia apibendrinta išraiška: 


$$
\left\{\begin{array}{l}
K, 1: \Phi_{1}=\Phi_{1}\left(v_{n k, n e}, k_{n k, n e}\right)=0 ; \\
K, 2: \Phi_{2}=\Phi_{2}\left(v_{n k, n e}, k_{n k, n e}\right)=0 .
\end{array}\right.
$$

Visos sistemos pusiausvyra aprašoma lygtimi:

$$
\Phi=\sum_{n k=1}^{k s} p_{n k, 1}(k v)_{n k, 1}-\sum_{n k=1}^{k s} p_{n k, 2}(k v)_{n k, 2}=0 .
$$

čia funkcijos $\Phi_{1}$ ir $\Phi_{2}$ atitinkamai yra ieinančiu ị sankryžą ir išeinančiu iš sankryžos TS funkcijos išreiškiamos per TS parametrus $k$ ir $v ; p_{\mathrm{nk}, \mathrm{ne}}$ ir $p_{\mathrm{nk}, 2}$ atitinkamai yra suminès TS srauto patekimo ị sankryžą tikimybès; $k$ ir $v$ yra TS koncentracijos ir greičio parametrai; $k s$ - ieinančiu ir išeinančiu iš sankryžos kelių skaičius; $n k$ - ieinančiu i sankryžą ir išeinančių jos kelių numeriai; $n e-$ ieinančių ị sankryžą ir išeinančiu jos eismo juostų numeriai.

Šia lygtimi apibrèžiamos patenkančiu i sankryžą srautų ir iš jos išeinančiu srautu sąlygos, t. y. kokia suminè srauto verte patenka ị sankryžą - tokia iš jos turi ir išeiti.

Jeigu TS sankryžoje gali išsidalinti i 2 ar daugiau TS šis transporto srautụ išsidalinimas aprašomas ịvedant papildomas tikimybiu išraiškas. İeinančio i sankryžą TS tikimybe turi būti lygi išeinančių TS tikimybių sumai ir ši suma turi būti mažesnè arba lygi 1 .

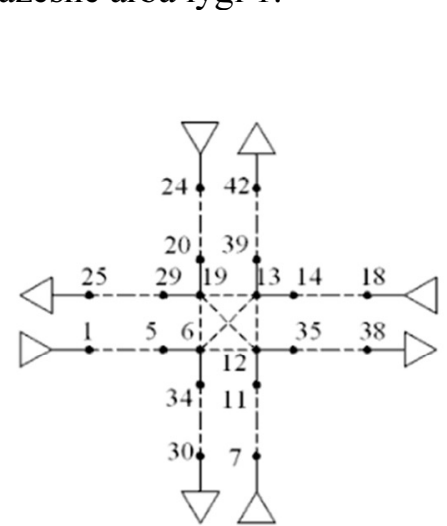

a)

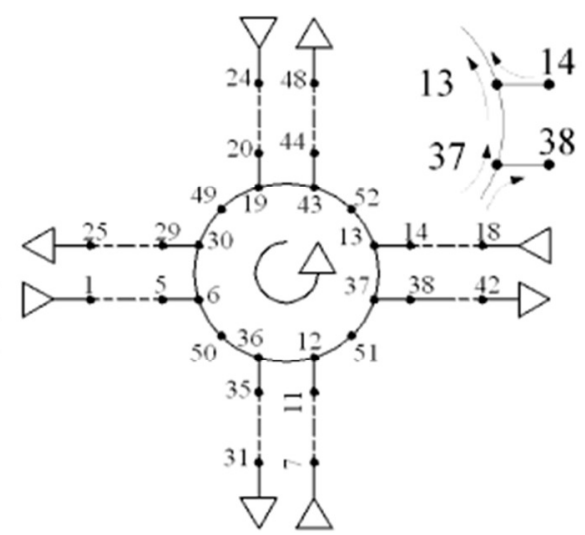

b)

2.10 pav. Transporto srautų sankryžos: a - keturių kelių, kuriuose yra po vieną priešpriešinio eismo juostą sankryža; b - žiedinė sankryža su keturiomis įeinančiomis ir keturiomis išeinančiomis eismo juostomis

Fig. 2.10. Intersections of traffic flow: $a-$ four road intersection, $b$ - roundabout intersection

Transporto srautu patekimo i sankryžą tikimybės aprašomos tokiomis matematinèmis išraiškomis: 


$$
\begin{aligned}
& p_{1,1,2,2}+p_{1,1,3,2}+p_{1,1,4,2}=p_{1,1} \leq 1 ; \\
& p_{2,1,1,2}+p_{2,1,3,2}+p_{2,1,4,2}=p_{2,1} \leq 1 ; \\
& p_{3,1,2,2}+p_{3,1,3,2}+p_{3,1,4,2}=p_{3,1} \leq 1 ; \\
& p_{4,1,2,2}+p_{4,1,3,2}+p_{4,1,4,2}=p_{4,1} \leq 1 ; \\
& \sum_{i=1}^{4} p_{k, i, 2}=p_{k, 1} \leq 1 ; \\
& i \neq k .
\end{aligned}
$$

TS išejjimo iš sankryžos tikimybès aprašomos tokiomis matematinėmis išraiškomis:

$$
\begin{aligned}
& p_{1,1,2,2}+p_{3,1,2,2}+p_{4,1,2,2}=p_{2,2} \leq 1 ; \\
& p_{1,1,3,2}+p_{2,1,3,2}+p_{4,1,3,2}=p_{3,2} \leq 1 ; \\
& p_{1,1,4,2}+p_{2,1,4,2}+p_{3,1,4,2}=p_{4,2} \leq 1 ; \\
& p_{2,1,1,2}+p_{3,1,1,2}+p_{4,1,1,2}=p_{1,2} \leq 1 ; \\
& \sum_{i=1}^{4} p_{k, i, 2}=1 ; \\
& i=1 \ldots 4 \text { ir } i \neq k ;
\end{aligned}
$$

Matematinis sankryžos modelis laikomas suderintu, kai įeinantys ị sankryžą automobilių srautas yra lygus išeinančiam automobilių srautui. Iprastai imama jog sankryžos pralaidumas yra mažesnis už tiesios atkarpos pralaidumą.

\subsubsection{Automobilių transporto srautų, kaip netiesinès dinaminès sistemos, modelio lygčių stabilumo įvertinimas}

Siekiant ivvertinti sukurto matematinio modelio stabilumą nustatomos sistemos tikrinès reikšmès. Sistema laikoma stabilia, kai sistemos tikrinių reikšmių realiosios dalys yra neigiamos.

Kadangi sistema gali turèti be galo daug mazgų, kuriuose užrašytos automobilių transporto srautus aprašančios lygtys stabilumas nustatomas sistemai, kurią sudaro keturi mazgai išdèstyti vienoje tiesejje. Pirmas ir paskutinis mazgas yra atitinkamai, šios mažos sistemos, ịvesties ir išvesties mazgas. Antras ir trečias mazgai - sistemos vidiniai mazgai.

Sistema yra su vèlavimu, todèl tikrinès reikšmès skaičiuojamos pagal tokią bendro pobūdžio išraišką:

$$
\{X\}=\left[A_{0}\right]\{X(t)\}+\left[A_{1}\right]\left\{X\left(t-\tau_{12}\right)\right\},
$$


čia $\{X\}=\left\{\begin{array}{l}k \\ v\end{array}\right\}-$ nežinomujų vektorius kiekviename kelio atkarpos mazge; $\tau_{12}-$ vèlavimo laikas tarp mazgų 1 ir 2; A - matrica.

Lygties 2.55 kintamojo sprendinys užrašomas sekančia forma:

$$
\begin{gathered}
\{X\}=\{Z\} e^{\lambda t}, \\
\left\{X\left(t-\tau_{12}\right)\right\}=\{Z\} e^{\lambda\left(t-\tau_{12}\right)} .
\end{gathered}
$$

Tada sistemos tikrines reikšmes galima nustatyti iš išraiškos:

$$
\lambda\{Z\} e^{\lambda t}=\left[A_{0}\right]\{Z\} e^{\lambda t}-\left[A_{1}\right]\{Z\} e^{\lambda\left(t-\tau_{12}\right)} .
$$

Išsprendus lygčių sistemą (2.49) nustatomos sistemos tikrinės reikšmės

$$
(\lambda[E]-[A(\lambda, \tau)])\{Z\}=0,
$$

čia $E$ - vienetinis vektorius.

\subsection{Antrojo skyriaus išvados}

1. TS lygtis, kurios yra sukurtos kinetinès teorijos pagrindu, prieš sprendžiant skaitiniais metodais iš lygčių su dalinėmis išvestinèmis reikia perrašyti ị algebrines išraiškas.

2. Sukurto universalaus transporto srauto, kaip netiesinès dinaminès sistemos, modelio lygtis galima be papildomo perrašymo spręsti skaitiniais metodais, pavyzdžiui Rungès ir Kuto metodu.

3. Sprendžiant lygtis charakteristikų metodu reikia užtikrinti stabilumo sąlygas (Kuranto sąlyga). Kuranto sąlyga priklauso nuo greičio, greitis yra kintamas, todèl charakteristikų tinklas yra nepastovus. 



\section{Transporto srautu matematinių modelių ir eksperimentų rezultatu palyginimas}

Šio skyriaus medžiaga buvo publikuota straipsniuose: Junevičius et al. (2011, 2007), Junevičius, Bogdevičius (2009, 2008, 2007).

\subsection{Tiesios kelio atkarpos modeliavimas pasitelkiant klasikinių automobilių transporto srautų modelių lygtis}

Šiame skyriuje pateikiami klasikinių, kontinuumo modelių automobilių transporto srautams modeliuoti, pavyzdžiai. Pagrindinis dèmesys nukreipiamas i kinetinès dujų teorijos pagrindu sukurtą modelį. Teorinès ši modeli aprašančios lygtys pateiktos 2.2.1 poskyryje. Pavyzdyje pateiktam modeliui sudaryti naudojamos 2.1.1 poskyryje pateiktos prielaidos.

Nagrinejjamas pavyzdys - tiesi 1-os eismo juostos atkarpa neturinti atsišakojimų ar papildomų eismo juostų ijungimų. Eismo juosta sudalinta $\mathfrak{i}$ trumpas atkarpèles, kurių ilgis $L_{i-1, i}=L_{i+1, i}=20 \mathrm{~m}$, kai $i=1$...80. Bendras eismo juostos 
ilgis $1600 \mathrm{~m}$. Uždavinys sprendžiamas charakteristiku metodu, todèl, kiekviename eismo juostos mazge išskyrus kraštinius sprendžiama (2.18), (2.19) lygčių sistema ir nustatomi automobilių transporto srauto parametrai: koncentracija ir srauto greitis $(k$ ir $v)$. Kraštiniuose mazguose įvedami apribojimai, kuriu reikalauja pats metodas. Tiek pirmame tiek paskutiniame nagrinèjamos eismo juostos mazge vienas iš ieškomu parametru yra pasirenkamas visam modeliuojamo laiko intervalui. Nagrinèjamame pavyzdyje, pirmajame mazge, kaip žinomas parametras pasirenkamas transporto srauto greitis, o paskutiniame eismo juostos mazge - automobilių transporto srauto koncentracija. Pirmu nagrinejjamu atveju tiek automobiliu transporto srauto greitis, tiek koncentracija pasirenkami kaip laike nekintantys dydžiai, kurių vertės yra šios: automobilio transporto srauto greitis pirmame mazge $v_{1}=9,72$ $\mathrm{m} / \mathrm{s}$, o koncentracijos reikšme pirmame mazge skaičiuojama pagal išraišką:

$$
k_{1}^{t+\Delta t}=k_{1}^{t}+C^{-} \cdot J_{2,1} .
$$

Paskutiniame mazge užduodama automobilio transporto srauto koncentraci$\mathrm{ja}-k_{81}=k_{\max }=0,18$ auto $/ \mathrm{m}$, o transporto srauto greitis skaičiuojamas pagal išraišką:

$$
v_{81}^{t+\Delta t}=v_{81}^{t}+C^{+} \cdot J_{1,2} .
$$

Visuose likusiuose mazguose transporto srauto greitis skaičiuojamas pagal išraišką:

$$
v_{81}^{t+\Delta t}=v_{i}^{t}+\Delta v_{i},
$$

o transporto srauto koncentracija skaičiuojamas pagal išraišką:

$$
k_{i}^{t+\Delta t}=k_{i}^{t}+\Delta k_{i} .
$$

Lygtyse (3.3) ir (3.4) kintamojo $i$ kitimo intervalas yra $i=2,3, \ldots, 80$. Lygtyse (3.1) ir (3.2) pateikti parametrai $J_{1,2}, J_{2,1}$, - Jakobio matricos elementai. Reikšmès $C^{+}$ir $C^{-}$yra atitinkamai charakteristiku tinklelio pliusinè ir minusinè charakteristikos mazgo $i$ atžvilgiu pateiktos išraiškose (2.18) ir (2.19).

Jakobio matrica šiam uždaviniui atrodo taip:

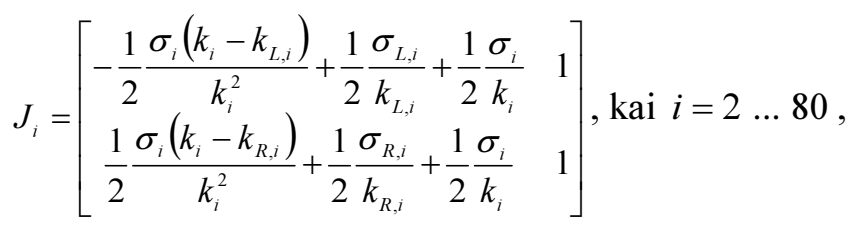


čia $k_{L}, k_{R}$ - atitinkamai kairès ir dešinès pusès patikslintos taško $i$ atžvilgiu automobilių transporto srauto koncentracijų reikšmès skaičiuojamos charakteristikų tinklelio mazguose. $\sigma_{L}, \sigma_{R}$-atitinkamai kairès ir dešinès pusès patikslintos taško $i$ atžvilgiu automobilių transporto srauto greičio nuokrypio reikšmès skaičiuojamos charakteristikų tinklelio mazguose. Detalesnè informacija apie pateikta 2.2.3 skyrelyje. Lygtyse (3.3) ir (3.4) pateiktos $\Delta k_{i}, \Delta v_{i}$, reikšmės - atitinkamai automobiliu transporto srauto koncentracijos ir greičio pokyčiai, kurie skaičiuojami pagal išraišką:

$$
\left\{\begin{array}{l}
\Delta k \\
\Delta v
\end{array}\right\}_{i}=[J]_{i}^{-1}\left\{\begin{array}{l}
\Phi_{1} \\
\Phi_{2}
\end{array}\right\}, \text { kai } i=2 \ldots 80,
$$

čia $[J]^{-1}$ - atvirkštinè Jakobio matrica, $\left\{\begin{array}{c}\Phi_{1} \\ \Phi_{2}\end{array}\right\}-$ vektorius kuriame pateiktos $C^{+}$ ir $C^{-}$charakteristikos mazgo $i$ atžvilgiu ir jos skaičiuojamos pagal (2.18) ir (2.19) matematines išraiškas. Lygčių sistema (3.6) yra sistemos sprendinys kiekviename charakteristikų tinklelio mazge, kuris atitinka eismo juostos mazgą $i$, kai $i=2 \ldots 80$.

Visuose eismo juostos mazguose ribinès automobilių transporto srauto greičio reikšmès yra: mažiausia leistina $-0 \mathrm{~m} / \mathrm{s}$, didžiausia leistina $-12,5 \mathrm{~m} / \mathrm{s}$. Visuose eismo juostos mazguose ribinès automobilių transporto srauto koncentracijos reikšmès yra: mažiausia leistina -0 auto/m, didžiausia leistina 0,18 auto/m. Pradiniu laiko momentu visuose mazguose, išskyrus kraštinius, TS judèjimo greitis yra $5,55 \mathrm{~m} / \mathrm{s}$, o koncentracija 0,1 auto/m. Modeliavimo rezultatai pateikti 3.1 ir 3.2 paveiksluose.

Eismo juosta galutiniame mazge maksimaliai apkrauta. Per maždaug 8090 s nuo galutinio mazgo link pirmo eismo juostos mazgo pradeda užsipildyti ir kiti eismo juostos mazgai. Mazgai esantys arti paskutinio mazgo pilnai užsipildo per maždaug 100-120 s sistema, o visoje nagrinejjamoje kelio atkarpoje automobiliais visiškai neužsipildo. 3.2 paveiksle pastebimas automobilių koncentracijos didejjimas visuose eismo juostos mazguose. Kelio atkarpos gale šis didejjimas yra staigus. Tuo tarpu kelio atkarpos pradžioje koncentracija sumažeja, o maždaug po $80 \mathrm{~s}$ pradeda didèti. TS greitis gana staigiai krenta modeliavimo pradžioje ir išlieka artimas nuliui visą modeliavimo laiką. Dėsningumas, jog didèjant srauto koncentracijai srauto greitis mažèja, išlieka.

Antru nagrinejjamu atveju išlaikomos visos pirmojo atvejo sąlygos, pakeičiamas tik automobilių transporto srauto greitis pirmajame mazge. Naujas transporto srauto greitis: $v_{1}=11,11 \mathrm{~m} / \mathrm{s}$. Pradiniu laiko momentu visuose mazguose, išskyrus kraštinius, TS judejjimo greitis yra $5,55 \mathrm{~m} / \mathrm{s}$, o koncentracija 0,1 auto/m. Modeliavimo rezultatai pateikti 3.3 ir 3.4 paveiksluose. 


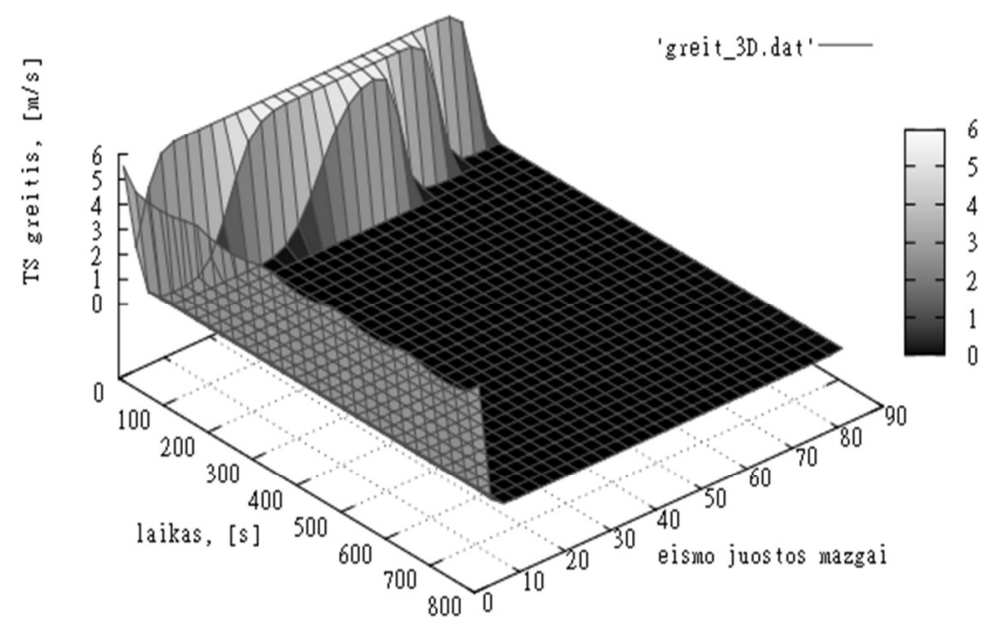

3.1 pav. Automobilių transporto srauto greitis mazguose $1-81$, kai

Fig. 3.1. Traffic flow speed at points $1-81$, when $v_{1}=9,72 \mathrm{~m} / \mathrm{s}, k_{81}=k_{\max }=$ 0,18 auto $/ m, v_{i}=5,55 \mathrm{~m} / \mathrm{s}, o k_{i}=0,1$ auto $/ m, i=2 \ldots 80$ $v_{i}=0 \ldots v_{\max }=12,5 \mathrm{~m} / \mathrm{s}, o k_{i}=0 \ldots k_{\max }=0,18$ auto $/ \mathrm{m}, \quad i=2 \ldots 80$

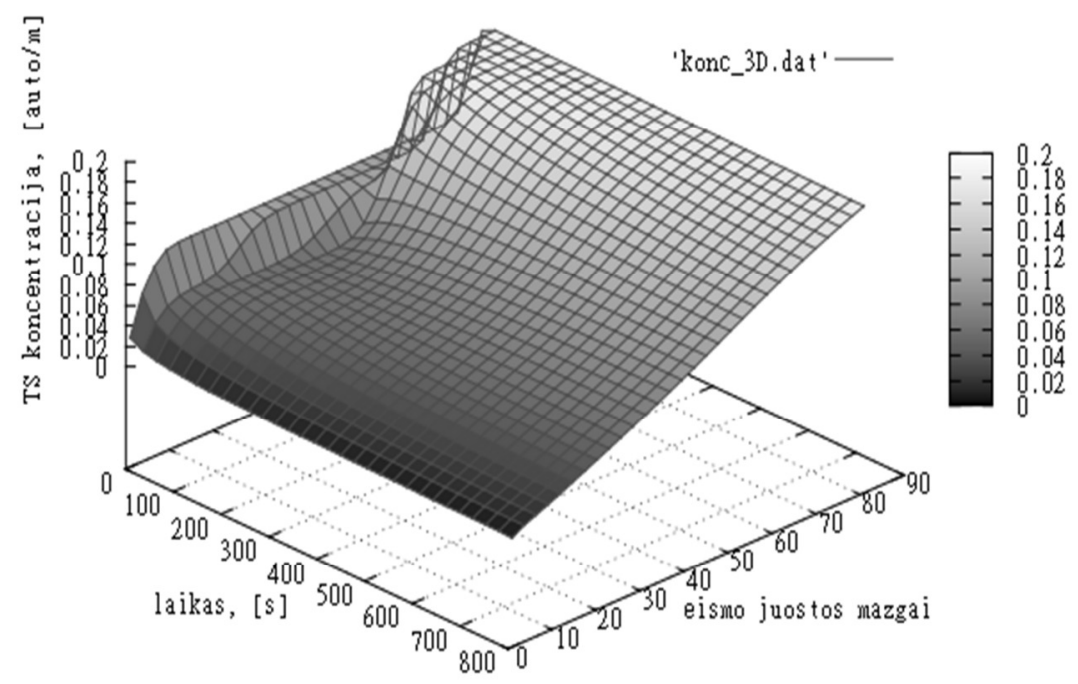

3.2 pav. Automobilių transporto srauto koncentracija mazguose 1-81, kai Fig. 3.2. Traffic flow concentration at points $1-81$, when $v_{1}=9,72 \mathrm{~m} / \mathrm{s}, k_{81}=$ $k_{\text {max }}=0,18$ auto $/ m, v_{i}=5,55 \mathrm{~m} / \mathrm{s}, o k_{i}=0,1$ auto $/ m, i=2 \ldots 80$ $v_{i}=0 \ldots v_{\max }=12,5 \mathrm{~m} / \mathrm{s}, o k_{i}=0 \ldots k_{\max }=0,18$ auto $/ \mathrm{m}, \quad i=2 \ldots 80$ 
Antruoju modeliavimo atveju greičio reikšmė pirmame mazge artima $\mathrm{v}_{\max }$ ir mazguose, kurie pirmieji eina po pirmojo mazgo, pastebimas automobiliu transporto srauto greičio ir koncentracijos parametrų šokčiojimas, kuris slopsta ir galiausiai visiškai išnyksta ties 20-30 mazgais. Koncentracijos ir srauto greičio reikšmès pokytis mazguose po 20 mazgo kinta analogiškai pirmam modeliavimo atvejui.

Trečiu nagrinejjamu atveju išlaikomos visos pirmojo atvejo sąlygos, pakeičiamas tik automobilių transporto srauto greitis pirmajame mazge. Naujas transporto srauto greitis: $v_{1}=v_{\max }=12,5 \mathrm{~m} / \mathrm{s}$. Pradiniu laiko momentu visuose mazguose, išskyrus kraštinius, TS judejimo greitis yra $5,55 \mathrm{~m} / \mathrm{s}$, o koncentracija 0,1 auto/m. Modeliavimo rezultatai pateikti 3.5 ir 3.6 paveiksluose.

Trečiuoju atveju, kai pasirinktas greitis pirmame mazge lygus $v_{\max }$ TS koncentracijos ir TS greičio vertès artejja prie didžiausių leistinų reikšmių, o ties $200 \mathrm{~s}$ riba TS greitis pradeda artèti prie $\infty$. Šis atvejis prieštarauja nusistovejusiam dèsningumui jog augant TS koncentracijai TS greitis mažèja ir atvirkščiai augant TS greičiui TS koncentracija mažeja. Vis dèlto po $250 \mathrm{~s}$ greičio reikšmè staigiai padideja iki max reikšmès, o koncentracija sumažeja iki 0 . Šiuo atveju dèsningumas galioja.

Ketvirtu nagrinèjamu atveju išlaikomos pirmojo atvejo sąlygos, pakeičiama tik automobilių transporto srauto koncentracija paskutiniajame mazge. Nauja transporto srauto koncentracija: $k_{81}=k_{1}$ auto/m. Pradiniu laiko momentu visuose mazguose, išskyrus kraštinius, TS judejjimo greitis yra $5,55 \mathrm{~m} / \mathrm{s}$, o koncentracija 0,1 auto/m. Modeliavimo rezultatai pateikti 3.7 ir 3.8 paveiksluose.

Ketvirtu modeliavimo atveju kai automobilio srauto greitis pirmame mazge $v_{1}=9,72 \mathrm{~m} / \mathrm{s}$, o koncentracija paskutiniame mazge $k_{81}=k_{1}$, auto $/ \mathrm{m}$ pusiausvyra sistemoje nenusistovi apie $900 \mathrm{~s}$ ir tik po 900-tosios, viso modeliavimui skirto laiko sekundès, pradeda arteti prie pusiausvyros padèties. Šiuo atveju gaunami teoriškai tiketini rezultatai, nes greičio reikšmè visuose mazguose nusistovi ties tarpine reikšme $(7,5 \mathrm{~m} / \mathrm{s})$. Gautoji reikšmė yra tarp galimos min ir max greičio reikšmių. Koncentracijos reikšmė visuose mazguose artejja prie 0 ir lieka artima 0 galutiniu laiko momentu. Tokie rezultatai gaunami dèl kraštiniuose mazguose pasirinktų TS parametrų skaitinių reikšmių. Kraštinèse sąlygose pasirinkta, jog i sistemą įvedama tokia pati srauto koncentracijos reikšmè kokia iš sistemos išvedama paskutiniame modeliuojamos kelio atkarpos mazge.

Penktu nagrinejjamu atveju išlaikomos ketvirto atvejo sąlygos, pakeičiamas tik automobiliu transporto srauto greitis pirmajame mazge. Naujas transporto srauto greitis: $v_{1}=v_{\max }=12,5 \mathrm{~m} / \mathrm{s}$. Pradiniu laiko momentu visuose mazguose išskyrus kraštinius TS judejjimo greitis yra $5,55 \mathrm{~m} / \mathrm{s}$, o koncentracija 0,18 auto/m. Modeliavimo rezultatai pateikti 3.9 ir 3.10 paveiksluose. 


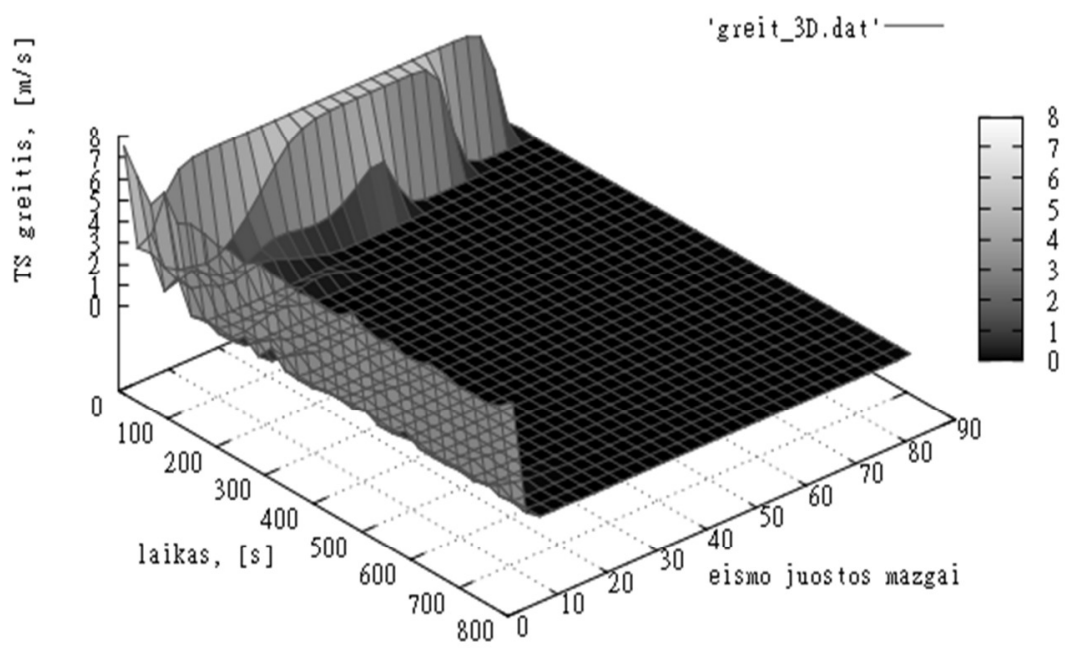

3.3 pav. Automobilių transporto srauto greitis mazguose $1-81$, kai

Fig. 3.3. Traffic flow speed at points $1-81$, when

$v_{1}=11,11 \mathrm{~m} / \mathrm{s}, k_{81}=k_{\max }=0,18$ auto $/ \mathrm{m}$,

$v_{i}=5,55 \mathrm{~m} / \mathrm{s}, o k_{i}=0,1$ auto $/ m, i=2 \ldots 80$

$v_{i}=0 \ldots v_{\max }=12,5 \mathrm{~m} / \mathrm{s}, o k_{i}=0 \ldots k_{\max }=0,18$ auto $/ \mathrm{m}, \quad i=2 \ldots 80$

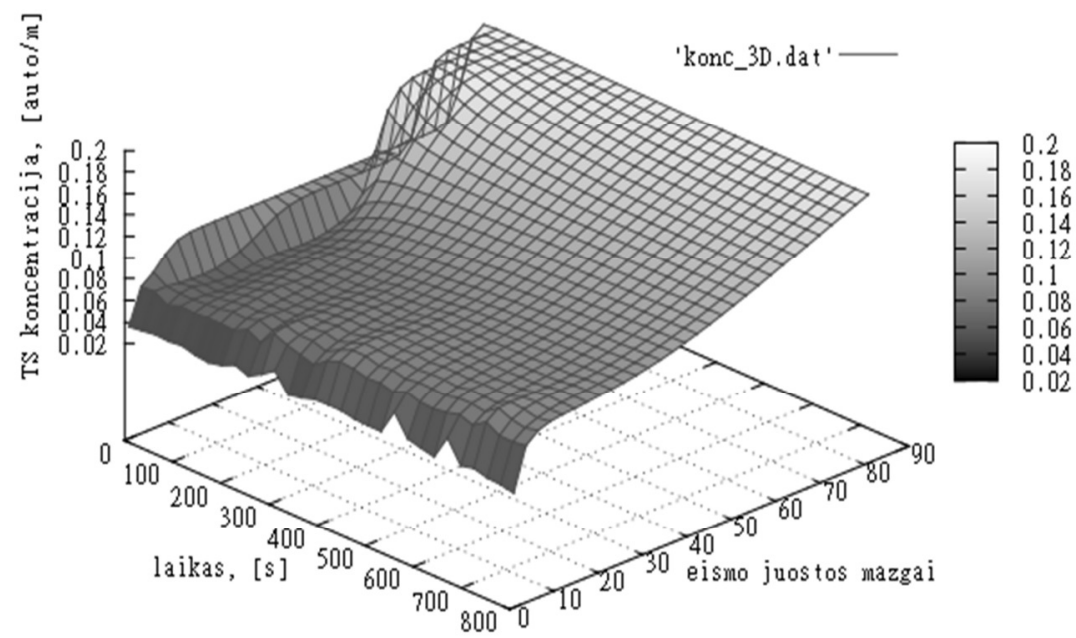

3.4 pav. Automobilių transporto srauto koncentracija mazguose 1-81, kai

Fig. 3.4. Traffic flow concentration at points $1-81$, when

$$
\begin{gathered}
v_{1}=11,11 \mathrm{~m} / \mathrm{s}, k_{81}=k_{\max }=0,18 \text { auto } / \mathrm{m} \\
v_{i}=5,55 \mathrm{~m} / \mathrm{s}, \text { o } k_{i}=0,1 \text { auto } / \mathrm{m}, i=2 \ldots 80 \\
v_{i}=0 \ldots v_{\max }=12,5 \mathrm{~m} / \mathrm{s}, o k_{i}=0 \ldots k_{\max }=0,18 \text { auto } / \mathrm{m}, i=2 \ldots 80
\end{gathered}
$$




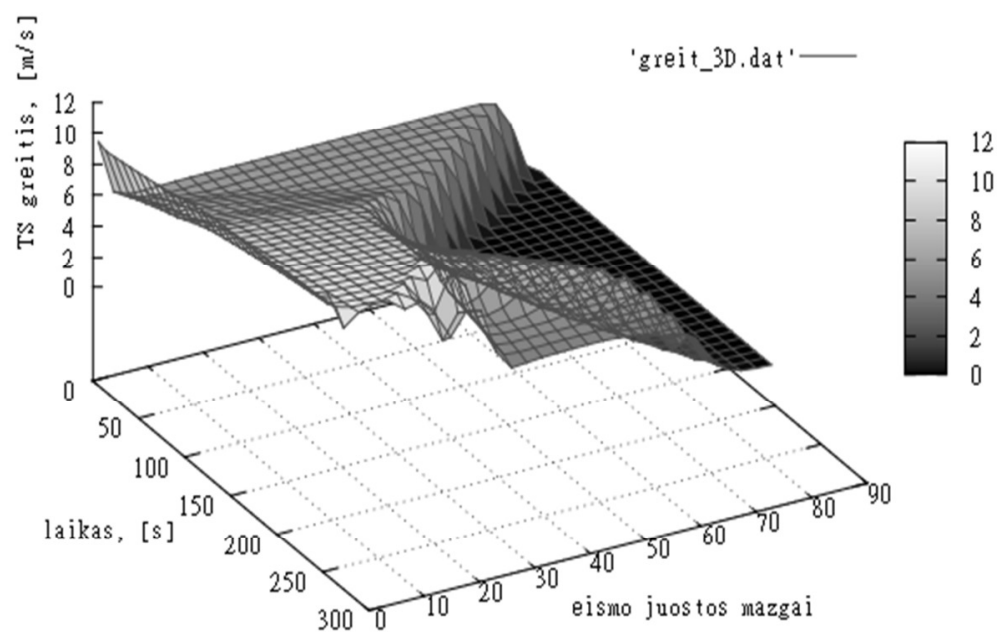

3.5 pav. Automobilių transporto srauto greitis mazguose $1-81$, kai

Fig. 3.5. Traffic flow speed at points $1-81$, when

$v_{1}=12,5 \mathrm{~m} / \mathrm{s}, k_{81}=k_{\max }=0,18$ auto $/ \mathrm{m}$,

$v_{i}=5,55 \mathrm{~m} / \mathrm{s}$, o $k_{i}=0,1$ auto $/ \mathrm{m}, i=2 \ldots 80$

$v_{i}=0 \ldots v_{\max }=12,5 \mathrm{~m} / \mathrm{s}, o k_{i}=0 \ldots k_{\max }=0,18$ auto $/ \mathrm{m}, \quad i=2 \ldots 80$

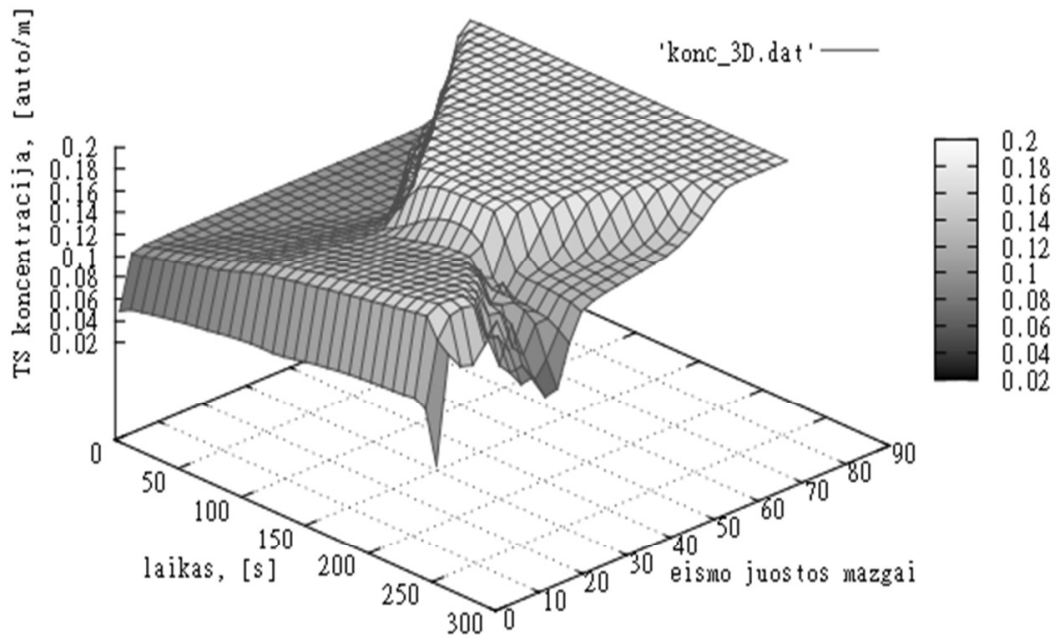

3.6 pav. Automobilių transporto srauto koncentracija mazguose 1-81, kai Fig. 3.6. Traffic flow concentration at points $1-81$, when

$$
\begin{gathered}
v_{1}=12,5 \mathrm{~m} / \mathrm{s}, k_{81}=k_{\max }=0,18 \text { auto } / \mathrm{m}, \\
v_{i}=5,55 \mathrm{~m} / \mathrm{s}, \text { o } k_{i}=0,1 \text { auto } / \mathrm{m}, i=2 \ldots 80 \\
v_{i}=0 \ldots v_{\max }=12,5 \mathrm{~m} / \mathrm{s}, o k_{i}=0 \ldots k_{\max }=0,18 \text { auto } / \mathrm{m}, i=2 \ldots 80
\end{gathered}
$$




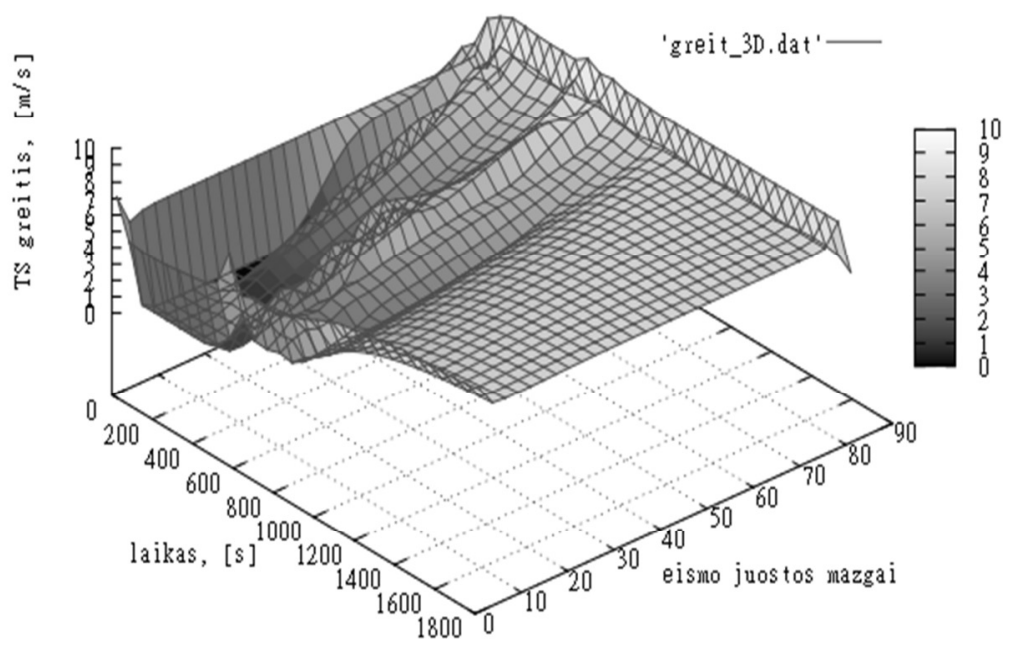

3.7 pav. Automobilių transporto srauto greitis mazguose $1-81$, kai Fig. 3.7. Traffic flow speed at points $1-81$, when $v_{1}=9,72 \mathrm{~m} / \mathrm{s}, k_{81}=k_{1}$, auto $/ \mathrm{m}$, $v_{i}=5,55 \mathrm{~m} / \mathrm{s}$, o $k_{i}=0,1$ auto $/ \mathrm{m}, i=2 \ldots 80$ $v_{i}=0 \ldots v_{\max }=12,5 \mathrm{~m} / \mathrm{s}$, o $k_{i}=0 \ldots k_{\max }=0,18$ auto $/ \mathrm{m}, \quad i=2 \ldots 80$

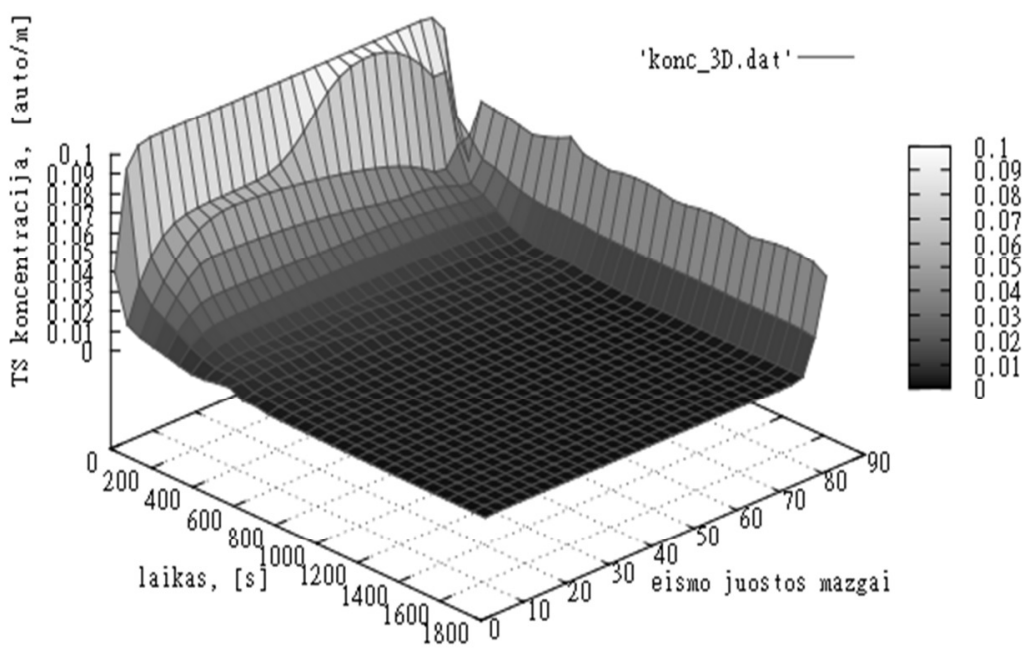

3.8 pav. Automobilių transporto srauto koncentracija mazguose $1-81$, kai Fig. 3.8. Traffic flow concentration at points $1-81$, when

$$
\begin{gathered}
v_{1}=9,72 \mathrm{~m} / \mathrm{s}, k_{81}=k_{1}, \text { auto } / \mathrm{m}, \\
v_{i}=5,55 \mathrm{~m} / \mathrm{s}, \text { o } k_{i}=0,1 \text { auto } / \mathrm{m}, \quad i=2 \ldots 80 \\
v_{i}=0 \ldots v_{\max }=12,5 \mathrm{~m} / \mathrm{s}, \text { o } k_{i}=0 \ldots k_{\max }=0,18 \text { auto } / \mathrm{m}, \quad i=2 \ldots 80
\end{gathered}
$$




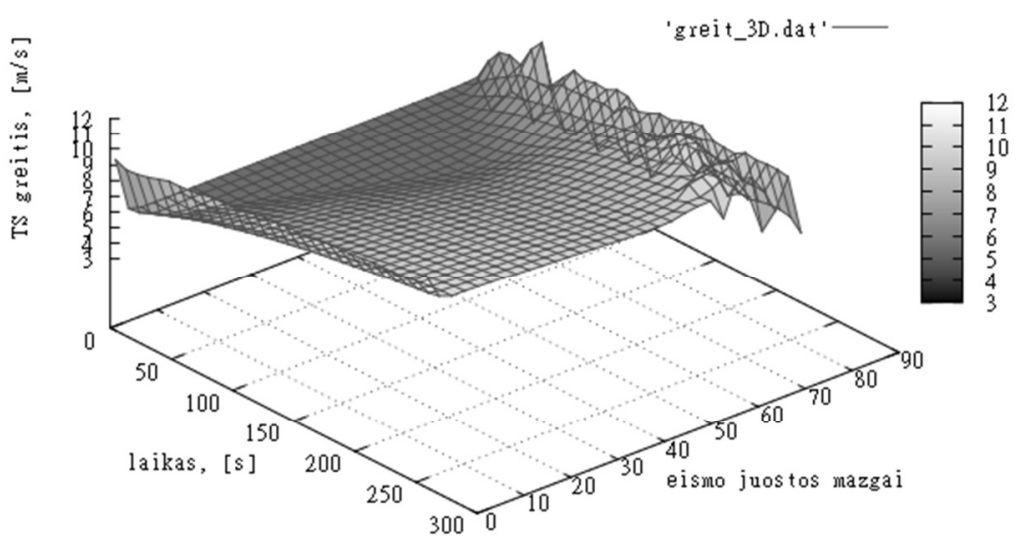

3.9 pav. Automobilių transporto srauto greitis $1-81$, kai

Fig. 3.9. Traffic flow speed at points $1-81$, when

$$
\begin{gathered}
v_{1}=v_{\max }=12,5 \mathrm{~m} / \mathrm{s}, k_{81}=k_{1}, \text { auto } / \mathrm{m} \\
v_{i}=5,55 \mathrm{~m} / \mathrm{s}, \text { o } k_{i}=0,1 \text { auto } / \mathrm{m}, \quad i=2 \ldots 80 \\
v_{i}=0 \ldots v_{\max }=12,5 \mathrm{~m} / \mathrm{s}, \mathrm{o}_{i}=0 \ldots k_{\max }=0,18 \text { auto } / \mathrm{m}, \quad i=2 \ldots 80
\end{gathered}
$$

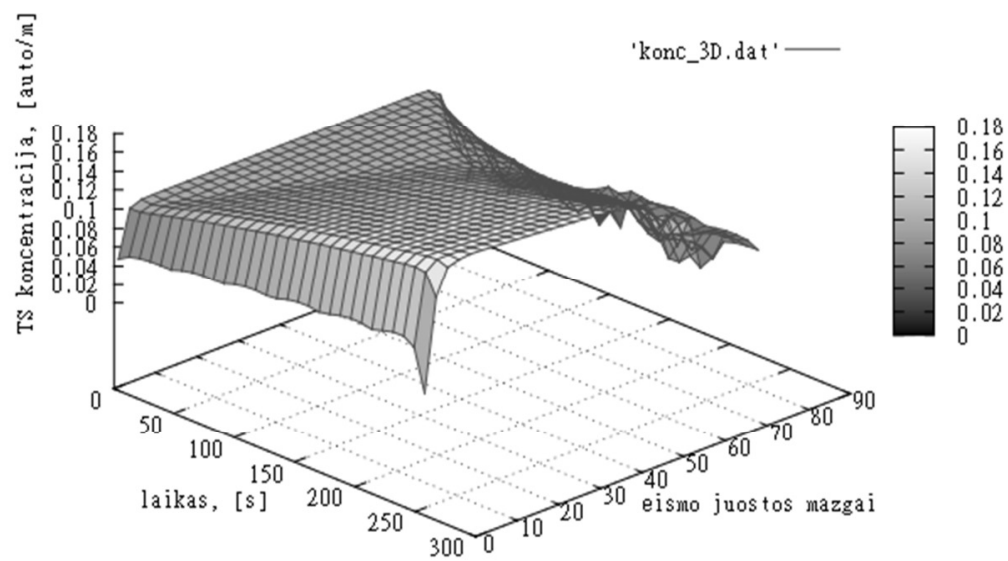

3.10 pav. Automobilių transporto srauto koncentracija mazguose 1-81, kai

Fig. 3.10. Traffic flow concentration at points $1-81$, when

$$
\begin{gathered}
v_{1}=v_{\max }=12,5 \mathrm{~m} / \mathrm{s}, k_{81}=k_{1}, \text { auto } / \mathrm{m} \\
v_{i}=5,55 \mathrm{~m} / \mathrm{s}, \text { o } k_{i}=0,1 \text { auto } / \mathrm{m}, \quad i=2 \ldots 80 \\
v_{i}=0 \ldots v_{\max }=12.5 \mathrm{~m} / \mathrm{s}, \text { o } k_{i}=0 \ldots k_{\max }=0.18 \text { auto } / \mathrm{m}, i=2 \ldots 80
\end{gathered}
$$

Penktu modeliavimo atveju, pirmame mazge įvedama max galima greičio vertè, o paskutiniame mazge išvedama ta pati koncentracijos reikšmé kokia paskaičiuojama pirmame mazge. Modeliavimo metu gautos TS greičio ir koncentracijos reikšmès prieštarauja nusistovejjusiai taisyklei, kai augant TS 
koncentracijai greitis turi mažèti. Gauti rezultatai rodo jog ir TS greičio, ir TS koncentracijos reikšmès dideja kartu ir galiausiai ties $230 \mathrm{~s}$ modeliavimas nutraukiamas, nes TS parametrų reikšmės šuoliškai priartèja prie $\infty$.

Bendru atveju modelis atkartoja schemą, kurios ir buvo tikètasi teoriškai augant srauto koncentracijos reikšmei, srauto greičio reikšmė mažejja ir atvirkščiai augant koncentracijos reikšmei srauto greičio reikšmẻ krenta. Kaip matyti iš gautų rezultatų modelį galima taikyti, kai transporto srauto reikšmès nepriartèja prie kritinių reikšmių.

\subsection{Tiesios kelio atkarpos modeliavimas pasitelkiant sutelktujuc parametrų automobilių transporto srautų modelio lygtis}

Šiame skyriuje pateikiami sutelktuju parametrų modelio, automobilių transporto srautams modeliuoti tiesioje eismo juostos atkarpoje, pavyzdžiai. Teorinès ši modeli aprašančios lygtys pateiktos 2.2 .4 poskyryje. Pavyzdyje pateiktam modeliui sudaryti naudojamos 2.1.1 poskyryje pateiktos prielaidos.

Uždavinio formuluote pateikta 3.1 poskyryje. Pats uždavinys sprendžiamas Rungès-Kutos metodu. Kiekviename eismo juostos mazge, išskyrus kraštinius, sprendžiama 2.34, 2.35 lygčių sistema ir nustatomi automobilių transporto srauto parametrai: koncentracija ir srauto greitis $(k$ ir $v)$.

Visuose eismo juostos mazguose ribinès automobiliu transporto srauto greičio reikšmės yra: mažiausia leistina $-0 \mathrm{~m} / \mathrm{s}$, didžiausia leistina $-12,5 \mathrm{~m} / \mathrm{s}$. Visuose eismo juostos mazguose ribinès automobiliu transporto srauto koncentracijos reikšmès yra: mažiausia leistina - 0 auto/m, didžiausia leistina 0,18 auto/m. Pradiniu laiko momentu visuose mazguose, išskyrus kraštinius, TS judejjimo greitis yra $5,55 \mathrm{~m} / \mathrm{s}$, o koncentracija $-0,1$ auto $/ \mathrm{m}$.

Pirmuoju modeliavimo atveju kraštiniuose mazguose yra ịvedimos tokios kintamujų reikšmės: pirmame mazge TS greitis $-9,72 \mathrm{~m} / \mathrm{s}$, TS koncentracija 0,01 auto $/ \mathrm{m}$; paskutiniame mazge TS greitis $-0,1 \mathrm{~m} / \mathrm{s}$, TS koncentracija 0,18 auto/m. Modeliavimo rezultatai pateikti 3.11 ir 3.12 paveiksluose.

Antru nagrinejjamu atveju išlaikomos visos pirmojo atvejo sąlygos, pakeičiamas tik automobilių transporto srauto greitis pirmajame mazge. Naujas transporto srauto greitis: $v_{1}=11,11 \mathrm{~m} / \mathrm{s}$. Pradiniu laiko momentu visuose mazguose, išskyrus kraštinius, TS judejimo greitis yra $5,55 \mathrm{~m} / \mathrm{s}$, o koncentracija $-0,1$ auto/m. Modeliavimo rezultatai pateikti 3.13 ir 3.14 paveiksluose.

Trečiu nagrinejamu atveju išlaikomos visos pirmojo atvejo sąlygos, pakeičiamas tik automobilių transporto srauto greitis pirmajame mazge. Naujas transporto srauto greitis: $v_{1}=v_{\max }=12,5 \mathrm{~m} / \mathrm{s}$. Pradiniu laiko momentu visuose 
mazguose, išskyrus kraštinius, TS judejimo greitis yra $5,55 \mathrm{~m} / \mathrm{s}$, o koncentracija $0,1 \mathrm{auto} / \mathrm{m}$. Modeliavimo rezultatai pateikti 3.15 ir 3.16 paveiksluose.

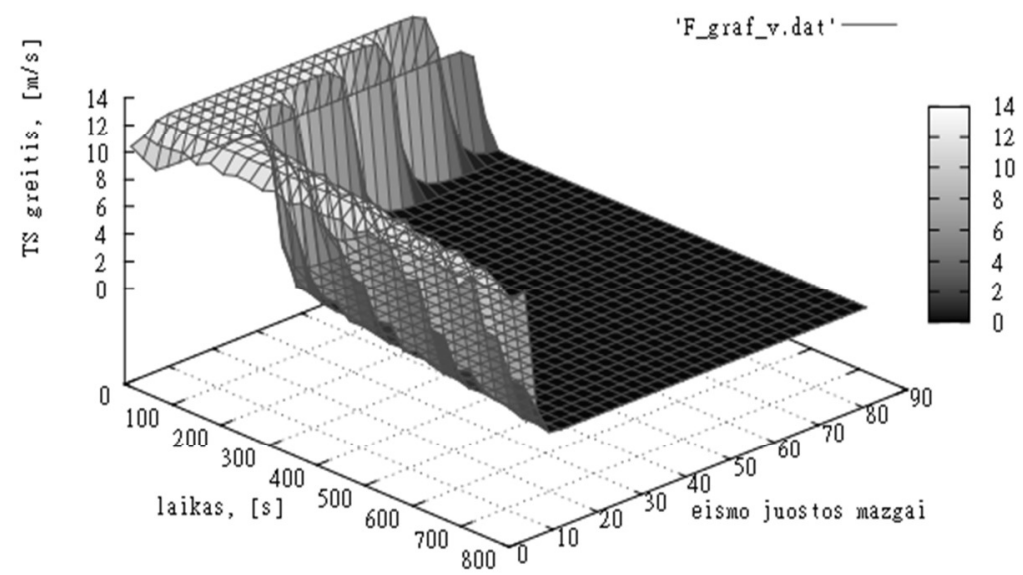

3.11 pav. Automobiliu transporto srauto greitis mazguose $1-81$, kai

Fig. 3.11. Traffic flow speed at points $1-81$, when

$$
\begin{gathered}
v_{1}=9,72 \mathrm{~m} / \mathrm{s}, k_{1}=0,01 \text { auto } / \mathrm{m}, v_{81}=0,1 \mathrm{~m} / \mathrm{s}, k_{81}=k_{\max }=0,18 \text { auto } / \mathrm{m}, \\
v_{i}=5,55 \mathrm{~m} / \mathrm{s}, o k_{i}=0,1 \text { auto } / \mathrm{m}, \quad i=2 \ldots 80 \\
v_{i}=0 \ldots v_{\max }=12,5 \mathrm{~m} / \mathrm{s}, o k_{i}=0 \ldots k_{\max }=0,18 \text { auto } / \mathrm{m}, i=2 \ldots 80
\end{gathered}
$$

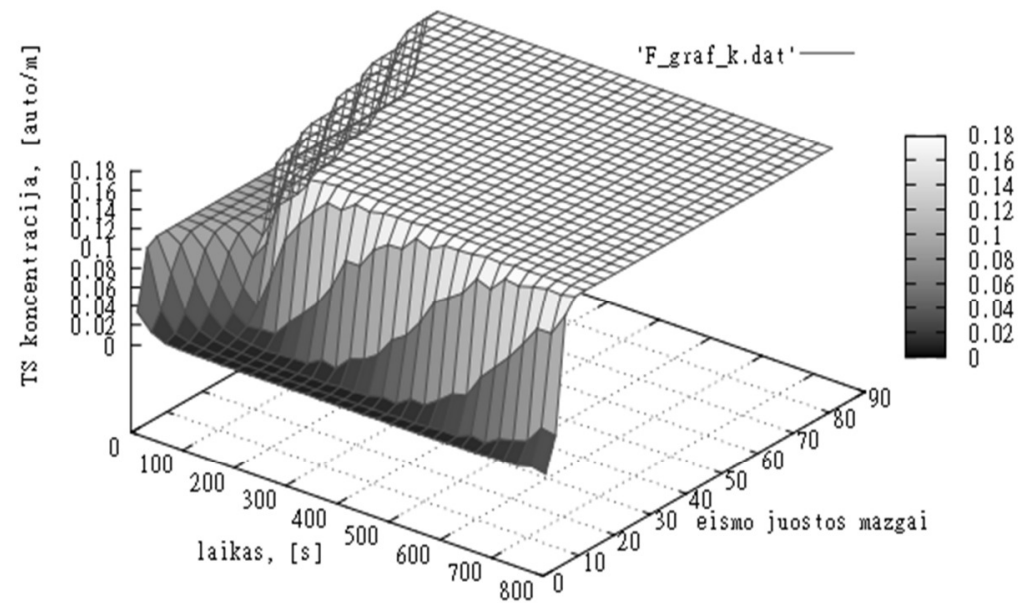

3.12 pav. Automobilių transporto srauto koncentracija mazguose 1-81, kai

Fig. 3.12. Traffic flow concentration at points $1-81$, when

$$
\begin{gathered}
v_{1}=9,72 \mathrm{~m} / \mathrm{s}, k_{1}=0,01 \text { auto } / \mathrm{m}, v_{81}=0,1 \mathrm{~m} / \mathrm{s}, k_{81}=0,18 \text { auto } / \mathrm{m}, \\
v_{i}=5,55 \mathrm{~m} / \mathrm{s}, o k_{i}=0,1 \text { auto } / \mathrm{m}, i=2 \ldots 80 \\
v_{i}=0 \ldots v_{\max }=12,5 \mathrm{~m} / \mathrm{s}, o k_{i}=0 \ldots k_{\max }=0,18 \text { auto } / \mathrm{m}, \quad i=2 \ldots 80
\end{gathered}
$$




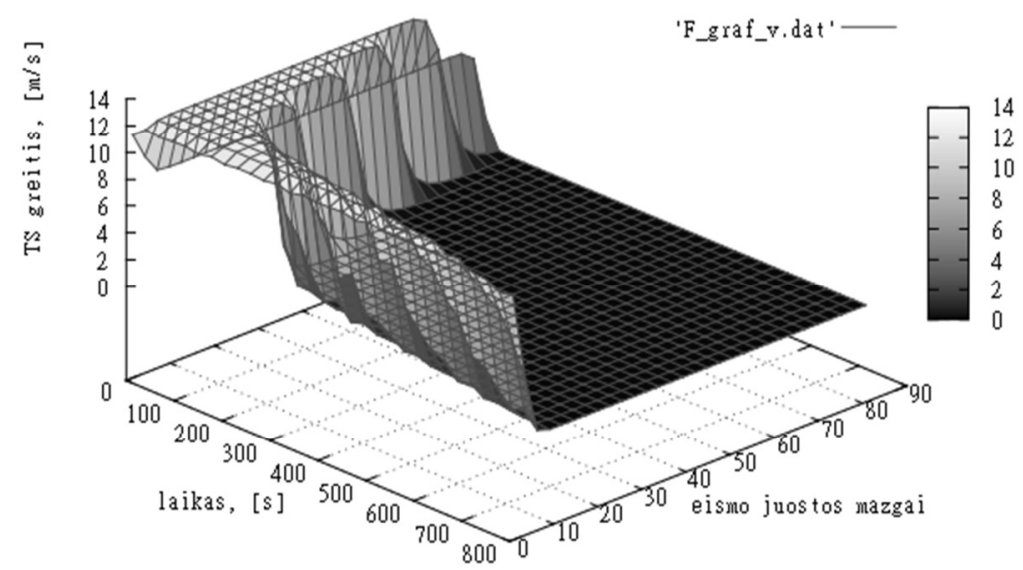

3.13 pav. Automobiliu transporto srauto greitis mazguose $1-81$, kai

Fig. 3.13. Traffic flow speed at points $1-81$, when

$v_{1}=11,11 \mathrm{~m} / \mathrm{s}, \quad k_{1}=0,01$ auto $/ \mathrm{m}, v_{81}=0,1 \mathrm{~m} / \mathrm{s}, k_{81}=k_{\max }=0,18$ auto $/ \mathrm{m}$, $v_{i}=5,55 \mathrm{~m} / \mathrm{s}, o k_{i}=0,1$ auto $/ \mathrm{m}, \quad i=2 \ldots 80$

$v_{i}=0 \ldots v_{\max }=12,5 \mathrm{~m} / \mathrm{s}, o k_{i}=0 \ldots k_{\max }=0,18$ auto $/ \mathrm{m}, \quad i=2 \ldots 80$

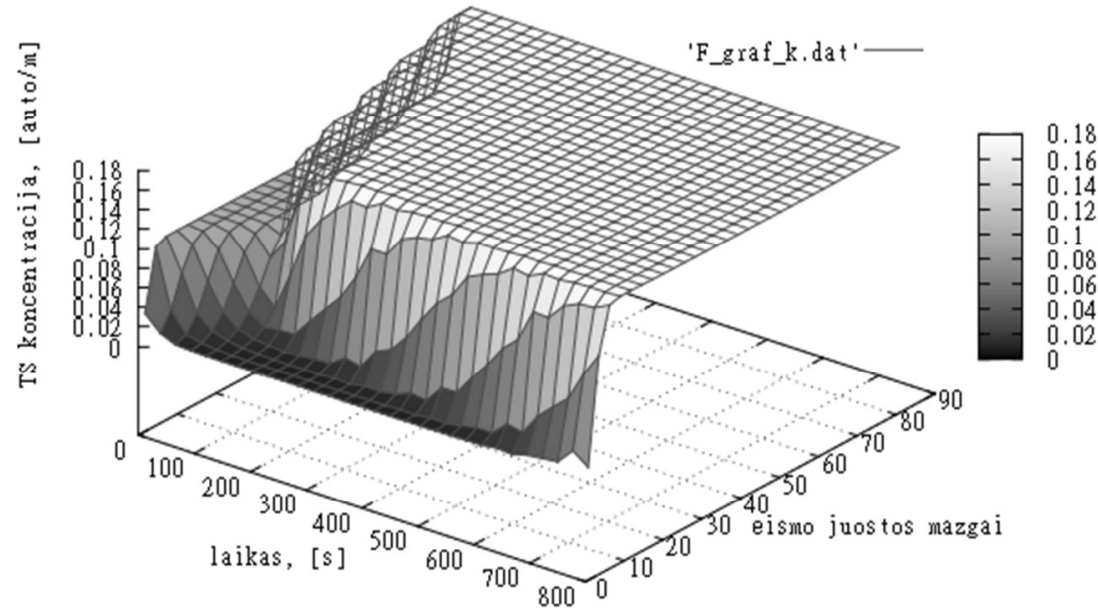

3.14 pav. Automobilių transporto srauto koncentracija mazguose $1-81$, kai

Fig. 3.14. Traffic flow concentration at points $1-81$, when

$v_{1}=11,11 \mathrm{~m} / \mathrm{s}, k_{1}=0,01$ auto $/ \mathrm{m}, v_{81}=0,1 \mathrm{~m} / \mathrm{s}, k_{81}=k_{\max }=0,18$ auto $/ \mathrm{m}$, $v_{i}=5,55 \mathrm{~m} / \mathrm{s}, o k_{i}=0,1$ auto $/ \mathrm{m}, \quad i=2 \ldots 80$

$v_{i}=0 \ldots v_{\max }=12,5 \mathrm{~m} / \mathrm{s}, o k_{i}=0 \ldots k_{\max }=0,18$ auto $/ \mathrm{m}, \quad i=2 \ldots 80$

Modeliuojant TS antruoju ir trečiuoju atvejais gauti rezultatai yra labai panašūs i pirmuoju atveju gautus modeliavimo rezultatus. Tokie panašumai yra 
tikètini nes modeliuojant yra pakeistas tik vienas parametras - TS greitis pirmame kelio atkarpos mazge, o koncentracija paskutiniam mazge lygi 0,18 auto/m. TS greitis yra didinamas nuo $9,72 \mathrm{iki} 12,5 \mathrm{~m} / \mathrm{s}$.

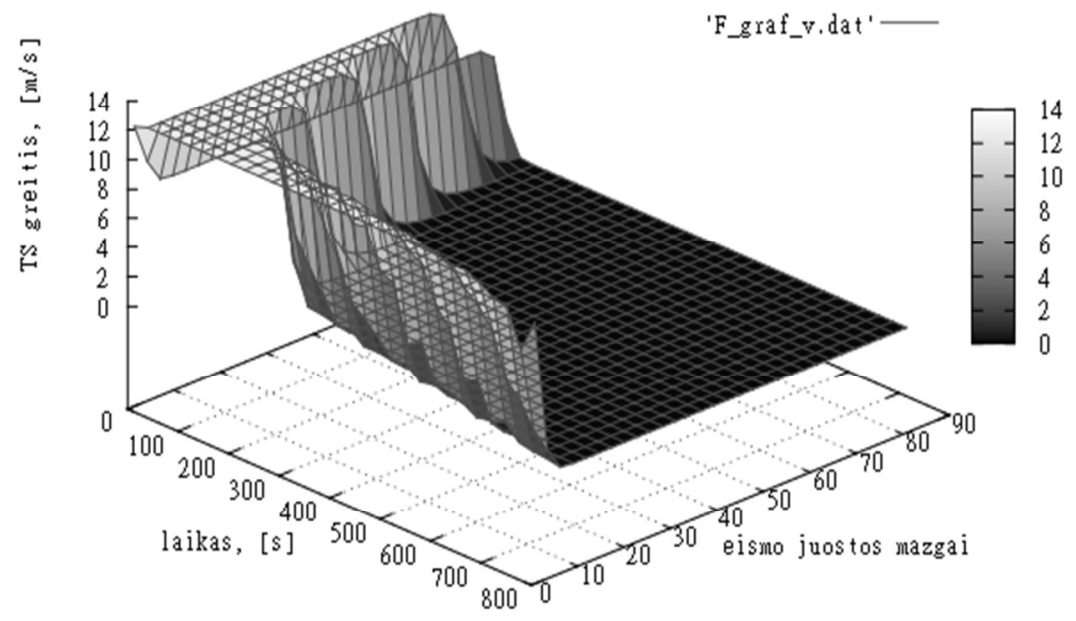

3.15 pav. Automobilių transporto srauto greitis mazguose $1-81$, kai

Fig. 3.15. Traffic flow speed at points $1-81$, when

$$
\begin{gathered}
v_{1}=12,5 \mathrm{~m} / \mathrm{s}, k_{1}=0,01 \mathrm{auto} / \mathrm{m}, v_{81}=0,1 \mathrm{~m} / \mathrm{s}, k_{81}=k_{\max }=0,18 \mathrm{auto} / \mathrm{m} ; \\
v_{i}=5,55 \mathrm{~m} / \mathrm{s}, k_{i}=0,1 \text { auto } / \mathrm{m}, i=2 \ldots 80 ; \\
v_{i}=0 \ldots v_{\max }=12,5 \mathrm{~m} / \mathrm{s}, \quad k_{i}=0 \ldots k_{\max }=0,18 \text { auto } / \mathrm{m}, i=2 \ldots 80
\end{gathered}
$$

Greičio pokytis pirmame kelio mazge modeliavimo rezultatus itakoja nedaug. TS greitis modeliavimo pradžioje padidejja nuo pradinio pasirinkto $(5,55 \mathrm{~m} / \mathrm{s})$ iki didžiausio galimo $(12,5 \mathrm{~m} / \mathrm{s})$ ir koncentracijai kelio mazguose didejjant krenta iki mažiausios galimos reikšmès, kuri yra lygi $0,1 \mathrm{~m} / \mathrm{s}$. TS greičio reikšmès pradeda kristi nuo paskutinio kelio atkarpos mazgo.

Koncentracijos, kaip ir greičio reikšmè pradeda augti nuo paskutinio kelio atkarpos mazgo ir po $200 \mathrm{~s}$ didžiojoje kelio dalyje pasiekia didžiausią galimą reikšmę $(0,18$ auto/m). Pirmuose 20 kelio mazgų pastebimas ryškus koncentracijos verčių kritimas, kuris pasiekia 0,02 auto/m reikšmę, bet po $200 \mathrm{~s}$ šios reikšmès pradeda didèti ir iki $800 \mathrm{~s}$ pasiekia didžiausią leistiną koncentracijos reikšmę, kuri yra lygi $0,18 \mathrm{~m} / \mathrm{s}$.

Ketvirtu nagrinejjamu atveju išlaikomos pirmojo atvejo sąlygos, pakeičiama tik automobiliu transporto srauto koncentracija paskutiniajame mazge. Nauja transporto srauto koncentracija: $k_{81}=k_{1}$, auto/m. Pradiniu laiko momentu visuose mazguose, išskyrus kraštinius, TS judejjimo greitis yra $5,55 \mathrm{~m} / \mathrm{s}$, o koncentracija 0.1 auto/m. Modeliavimo rezultatai pateikti 3.17 ir 3.18 paveiksluose. 


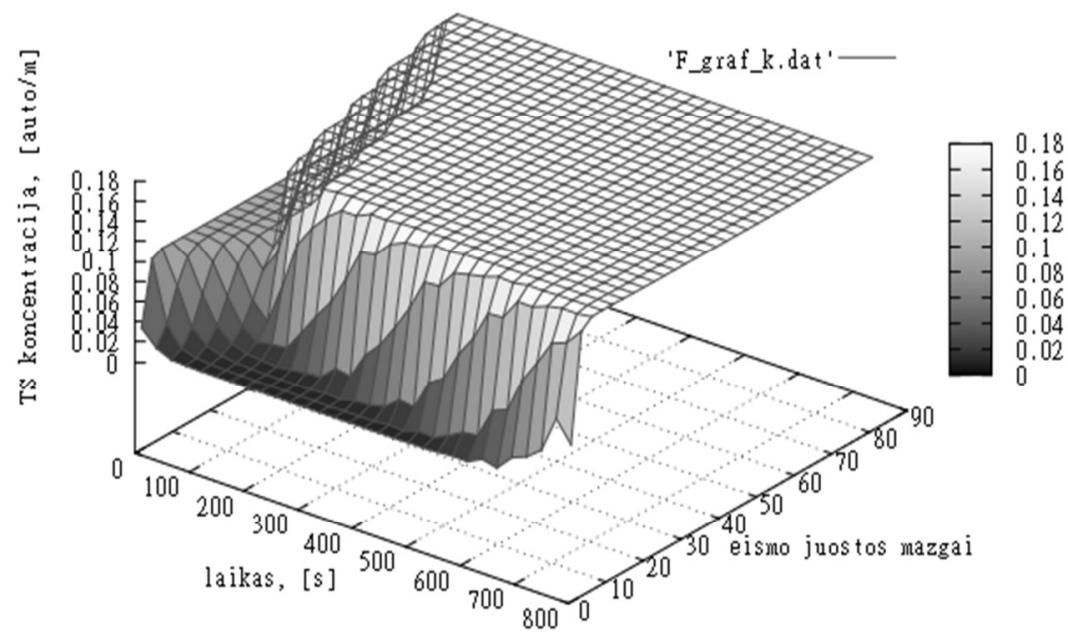

3.16 pav. Automobilių transporto srauto koncentracija mazguose 1-81, kai

Fig. 3.16. Traffic flow concentration at points $1-81$, when

$v_{1}=12,5 \mathrm{~m} / \mathrm{s}, \quad k_{1}=0,01$ auto $/ \mathrm{m}, v_{81}=0,1 \mathrm{~m} / \mathrm{s}, k_{81}=k_{\max }=0,18$ auto $/ \mathrm{m}$, $v_{i}=5,55 \mathrm{~m} / \mathrm{s}, o k_{i}=0,1$ auto $/ \mathrm{m}, \quad i=2 \ldots 80$

$v_{i}=0 \ldots v_{\max }=12,5 \mathrm{~m} / \mathrm{s}, o k_{i}=0 \ldots k_{\max }=0,18$ auto $/ \mathrm{m}, \quad i=2 \ldots 80$

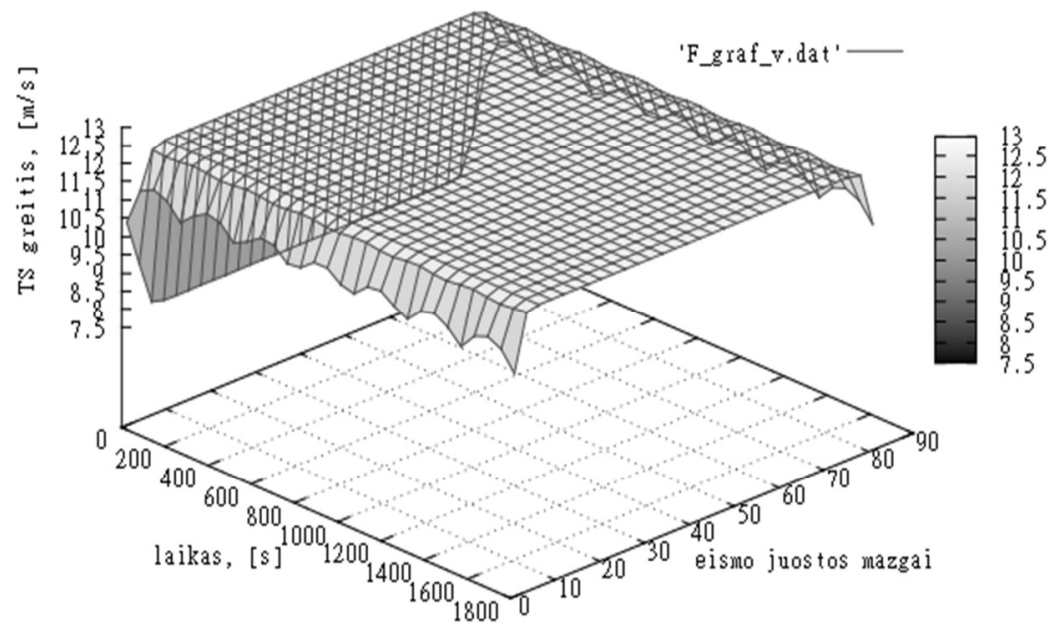

3.17 pav. Automobilių transporto srauto greitis mazguose 1-81, kai

Fig. 3.17. Traffic flow speed at points $1-81$, when

$v_{1}=9,72 \mathrm{~m} / \mathrm{s} k_{1}=0,01$ auto $/ \mathrm{m}, v_{81}=9,72 \mathrm{~m} / \mathrm{s}, k_{81}=0,01$ auto $/ \mathrm{m}$, $v_{i}=5,55 \mathrm{~m} / \mathrm{s}, o k_{i}=0,1$ auto $/ \mathrm{m}, \quad i=2-80$

$v_{i}=0 \ldots v_{\max }=12,5 \mathrm{~m} / \mathrm{s}, o k_{i}=0 \ldots k_{\max }=0,18$ auto $/ \mathrm{m}, \quad i=2 \ldots 80$ 


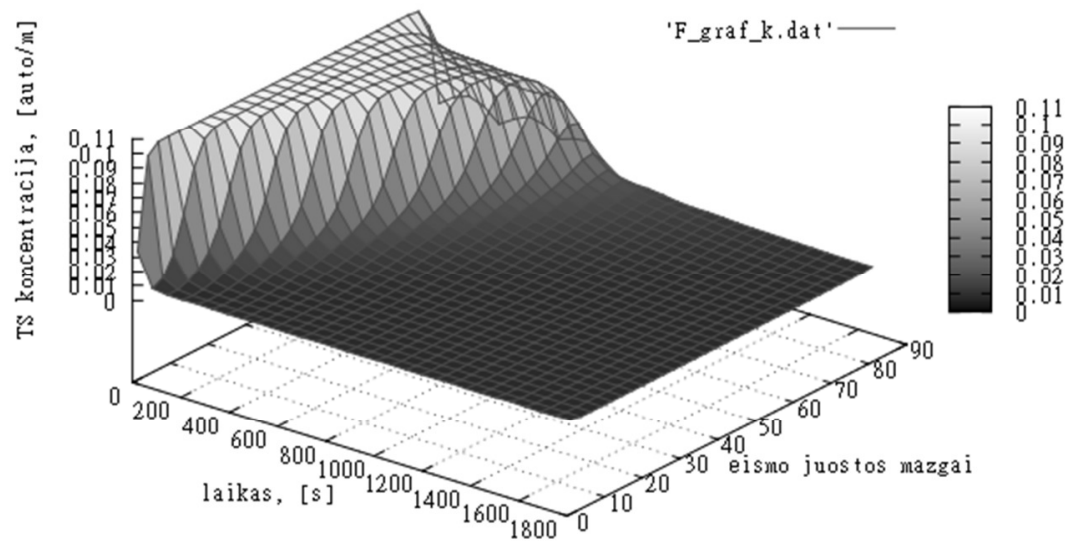

3.18 pav. Automobilių transporto srauto koncentracija mazguose 1-81, kai

Fig. 3.18. Traffic flow concentration at points $1-81$, when

$$
\begin{gathered}
v_{1}=9,72 \mathrm{~m} / \mathrm{s}, \quad k_{1}=0,01 \text { auto } / \mathrm{m}, v_{81}=9,72 \mathrm{~m} / \mathrm{s}, k_{81}=0,01, \text { auto } / \mathrm{m}, \\
v_{i}=5,55 \mathrm{~m} / \mathrm{s}, o k_{i}=0,1 \text { auto } / \mathrm{m}, i=2 \ldots 80 \\
v_{i}=0 \ldots v_{\max }=12,5 \mathrm{~m} / \mathrm{s}, o k_{i}=0 \ldots k_{\max }=0,18 \text { auto } / \mathrm{m}, \quad i=2 \ldots 80
\end{gathered}
$$

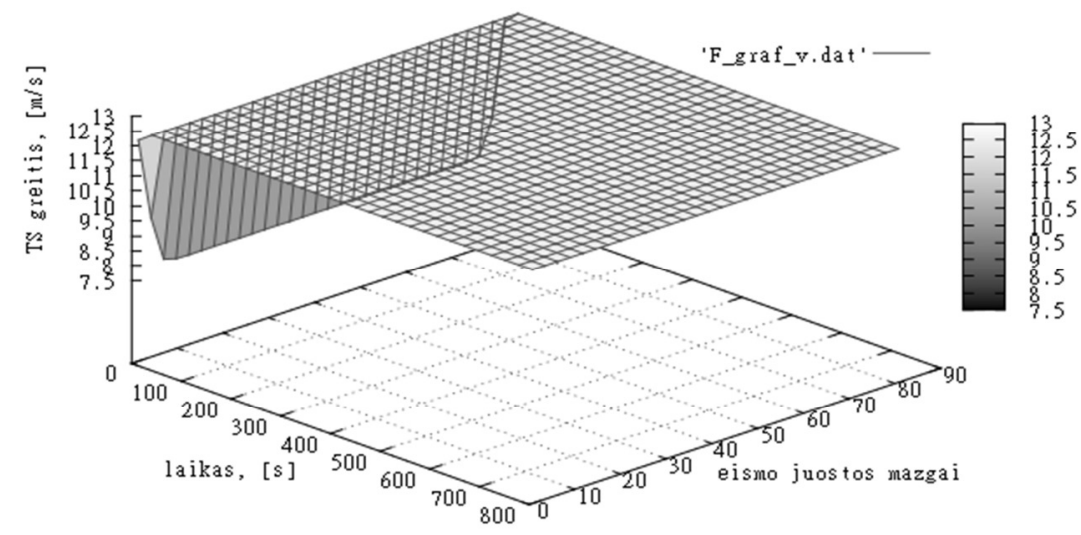

3.19 pav. Automobiliu transporto srauto greitis $1-81$, kai

Fig. 3.19. Traffic flow speed at points $1-81$, when

$$
\begin{gathered}
v_{1}=v_{\max }=12,5 \mathrm{~m} / \mathrm{s}, k_{1}=0,01 \text { auto } / \mathrm{m}, v_{81}=12,5 \mathrm{~m} / \mathrm{s}, k_{81}=0,01, \text { auto } / \mathrm{m}, \\
v_{i}=5,55 \mathrm{~m} / \mathrm{s}, o k_{i}=0,1 \text { auto } / \mathrm{m}, i=2 \ldots 80 \\
v_{i}=0 \ldots v_{\max }=12,5 \mathrm{~m} / \mathrm{s}, o k_{i}=0 \ldots k_{\max }=0.18 \text { auto } / \mathrm{m}, \quad i=2 \ldots 80
\end{gathered}
$$

Penktu nagrinėjamu atveju išlaikomos ketvirto atvejo sąlygos, pakeičiamas tik automobiliu transporto srauto greitis pirmajame mazge. Naujas transporto srauto greitis: $v_{1}=v_{\max }=12,5 \mathrm{~m} / \mathrm{s}$. Pradiniu laiko momentu visuose mazguose, išskyrus kraštinius, TS judejjimo greitis yra $5,55 \mathrm{~m} / \mathrm{s}$, o koncentracija 0,18 auto/m. Modeliavimo rezultatai pateikti 3.19 ir 3.20 paveiksluose. 


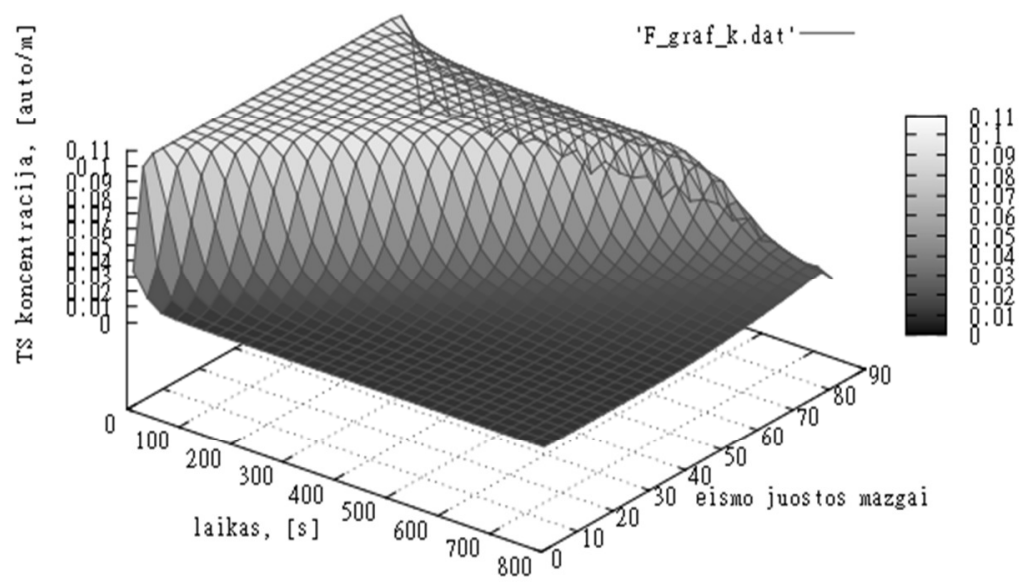

3.20 pav. Automobilių transporto srauto koncentracija mazguose 1-81, kai

Fig. 3.20. Traffic flow concentration at points $1-81$, when

$$
\begin{gathered}
v_{1}=v_{\max }=12,5 \mathrm{~m} / \mathrm{s}, k_{1}=0,01 \text { auto } / \mathrm{m}, \\
v_{81}=12,5 \mathrm{~m} / \mathrm{s}, k_{81}=0,01, \text { auto } / \mathrm{m}, \\
v_{i}=5,55 \mathrm{~m} / \mathrm{s}, o k_{i}=0,1 \text { auto } / \mathrm{m}, \quad i=2-80 \\
v_{i}=0 \ldots v_{\max }=12.5 \mathrm{~m} / \mathrm{s}, o k_{i}=0 \ldots k_{\max }=0.18 \text { auto } / \mathrm{m}, \quad i=2 \ldots 80
\end{gathered}
$$

Modeliuojant TS ketvirtu ir penktu atvejais gauti rezultatai yra labai panašūs tarpusavyje. Kaip ir $1-3$ atvejais greičio pokytis nuo 9,72 iki 12,5 m/s mažai įtakoja modeliavimo rezultatus.

Kraštiniuose kelio mazguose, pradiniu laiko momentu, pasirenkamos transporto srauto greičio reikšmès yra lygios: 4 atveju $-9,72 \mathrm{~m} / \mathrm{s}, 5$ atveju $-12,5$ $\mathrm{m} / \mathrm{s}$. Transporto srauto koncentracijos pradiniu laiko momentu kraštiniuose mazguose yra lygios: $0,01 \mathrm{~m} / \mathrm{s}$.

TS greitis 4 atveju greitai padideja nuo užduotos $9,72 \mathrm{~m} / \mathrm{s}$ greičio reikšmès iki didžiausios leistinos greičio reikšmès, kuri lygi $12,5 \mathrm{~m} / \mathrm{s}$ ir visą modeliavimo laiką išlieka pastovi. 5 atveju kraštiniuose mazguose pasirinkta greičio reikšmè buvo lygi didžiausiai leistinai greičio reikšmei. Abiem atvejais greičio reikšmé likusiuose mazguose, pradiniu laiko momentu, buvo lygi $5,55 \mathrm{~m} / \mathrm{s}, \quad$ o modeliuojant pakyla iki didžiausios leistinos greičio reikšmès ir visa modeliavimo laiką išlieka pastovi.

TS koncentracijos visoje kelio atkarpoje abiem atvejais kinta analogiškai, kadangi kelio atkarpos galuose ịvedamos greičio reikšmès yra didelès, lyginant su didžiausiu leistinu TS greičiu, o koncentracijos reikšmės yra mažos, tai per $800 \mathrm{~s}$ kelio atkarpa ištuštejja ir TS koncentracijos reikšmès priartëja prie 0 visuose kelio atkarpos mazguose. 


\subsection{Dujų kinetinio matematinio modelio ir sutelktujjų parametrų matematinio modelio palyginimas}

Šiame poskyryje palyginami dviejų, dujų kinetinio ir sutelktujų parametrų, matematinių modelių modeliavimo rezultatai, kurių matematinių eksperimentų rezultatai aprašyti 3.1 ir 3.2 poskyriuose.

Rezultatų palyginimui iš tiesios kelio atkarpos imamas 40 mazgas. Šis mazgas pasirenkamas todèl, kad yra vienodu atstumu nutolęs nuo modeliuojamos kelio atkarpos kraštinių mazgų. Kadangi kraštiniai mazgai yra nutolę nuo pasirinkto mazgo, todèl modeliavimo rezultatai šiame mazge tiksliau parodo visos sistemos būseną ir parametrų pokyčius visu modeliavimo laikotarpiu.

Eksperimento rezultatai lyginami grafiškai šiame poskyryje pateiktuose paveiksluose.

3.21 ir 3.22 paveiksluose tarpusavyje lyginami 1-as ir 2-as modeliavimo atvejai. Palyginimu pasirinkti būtent šie modeliavimo rezultatai, todèl, kad juose labai panašios modeliavimo sąlygos. TS greitis pirmame mazge abiem atvejais lygus $9,72 \mathrm{~m} / \mathrm{s}$, o TS koncentracija paskutiniame mazge lygi 0,18 auto/m.

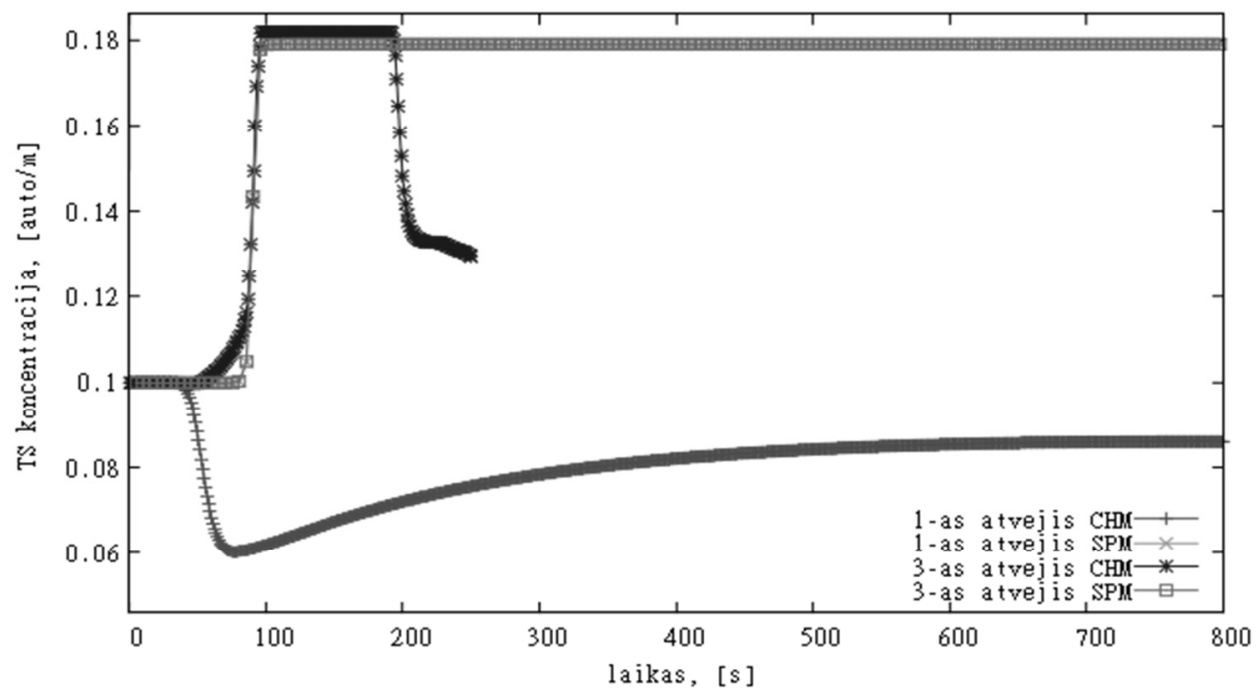

3.21 pav. TS koncentracijos pokyčio palyginimas 40-tame kelio atkarpos mazge, kai tarpusavyje lyginami duju kinetinio (CHM) ir sutelktu parametru (SPM) matematiniai modeliai 1-tu ir 3-tu modeliavimo atvejais

Fig. 3.21. The results of two models Gas kinetic (CHM) and model of concentrated parameters (SPM) are compared. Traffic flow concentration diagrams are taken from point 40 when 1-st and 3-rd modeling cases are compared 


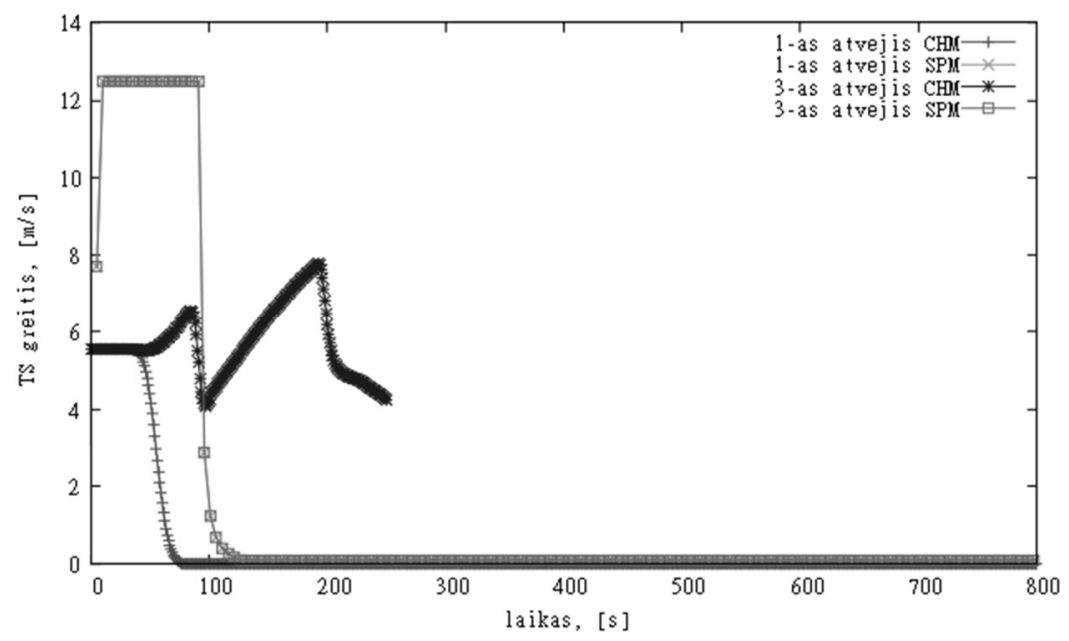

3.22 pav. TS greičio pokyčio palyginimas 40 -tame kelio atkarpos mazge, kai tarpusavyje lyginami duju kinetinio (CHM) ir sutelktų parametrų (SPM) matematiniai modeliai 1-tu ir 3-tu modeliavimo atvejais

Fig. 3.22. The results of two models Gas kinetic (CHM) and model of Concentrated parameters (SPM) are compared. Traffic flow speed diagrams are taken from point 40 when 1-st and 3-rd modeling cases are compared

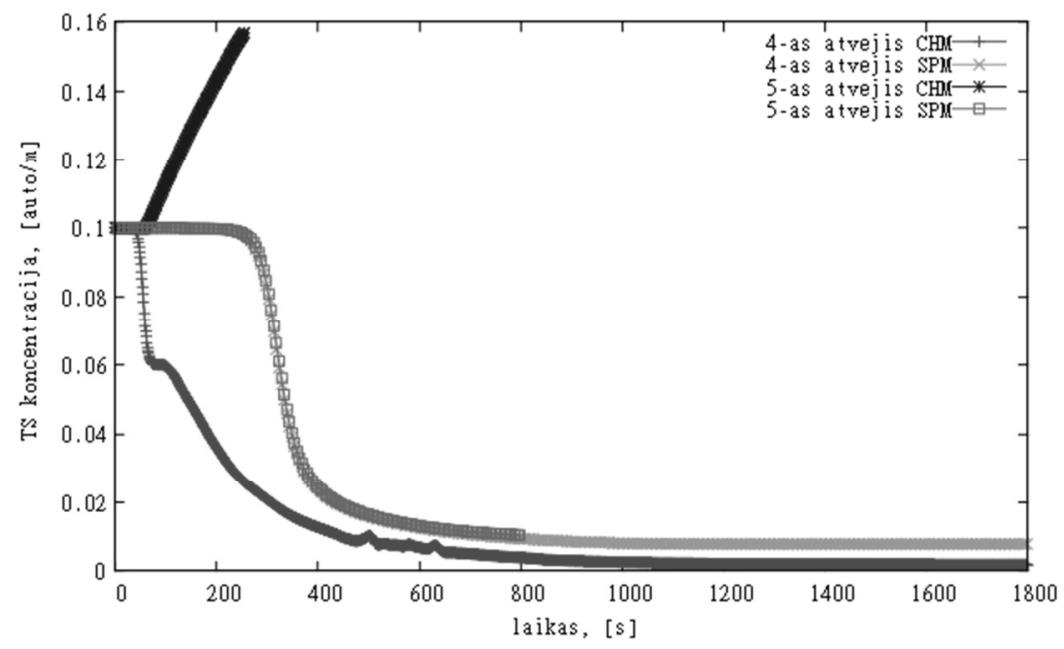

3.23 pav. TS koncentracijos pokyčio palyginimas 40-tame kelio atkarpos mazge, kai tarpusavyje lyginami duju kinetinio (CHM) ir sutelktų parametrų (SPM) matematiniai modeliai 4-tu ir 5-tu modeliavimo atvejais

Fig. 3.23. The results of two models Gas kinetic (CHM) and model of Concentrated parameters (SPM) are compared. Traffic flow concentration diagrams are taken from point 40 when 4 -th and 5-th modeling cases are compared 


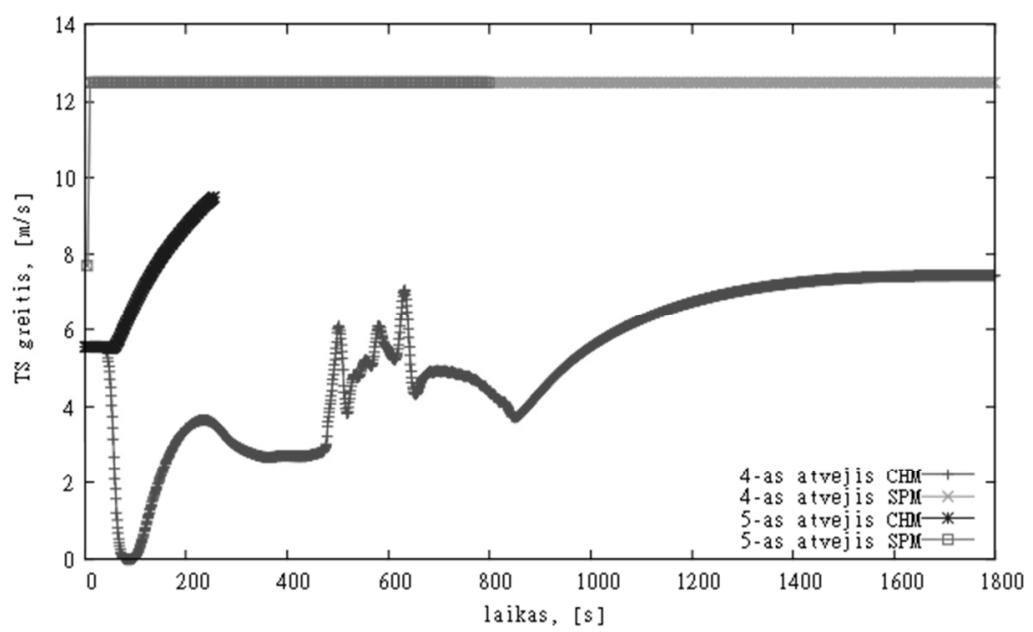

3.24 pav. TS greičio pokyčio palyginimas 40-tame kelio atkarpos mazge, kai tarpusavyje lyginami duju kinetinio (CHM) ir sutelktų parametrų (SPM) matematiniai modeliai 4-tu ir 5-tu modeliavimo atvejais

Fig. 3.24. The results of two models Gas kinetic (CHM) and model of Concentrated parameters (SPM) are compared. Traffic flow speed diagrams are taken from point 40 when 4-th and 5-th modeling cases are compared

Sprendžiant uždavinį charakteristikų metodu pirmame mazge antrasis nežinomas parametras yra TS koncentracija ir jis skaičiuojamas pagal išraišką (3.1) Šis parametras kinta priklausomai nuo reikšmių pokyčio 2-me mazge. Paskutiniame mazge antrasis nežinomas parametras yra TS greitis ir jis skaičiuojamas pagal išraišką (3.2). Jo reikšmès kinta priklausomai nuo 80 mazgo reikšmių.

Sprendžiant uždavinį Rungès ir Kuto metodu pirmame ir paskutiniame mazge pasirenkami abu nežinomi parametrai, todèl pirmame mazge TS koncentracija imama lygi 0,01 auto/m, o paskutiniame mazge TS greitis imamas lygus $0,1 \mathrm{~m} / \mathrm{s}$.

3.23 ir 3.24 paveiksluose tarpusavyje lyginami 4 -as ir 5-as modeliavimo atvejai. Palyginimu pasirinkti būtent šie modeliavimo rezultatai, todèl, kad juose labai panašios modeliavimo sąlygos. Transporto srauto greitis pirmame ir paskutiniame mazguose 4 -tu atveju lygus $9,72 \mathrm{~m} / \mathrm{s}$, o 5 -tu atveju $-12,5 \mathrm{~m} / \mathrm{s}$. TS koncentracija paskutiniame mazge sprendžiant uždavinį charakteristikų metodu lygi pirmo mazgo koncentracijai ir yra artima 0 auto/m, o sprendžiant uždavini Rungès ir Kuto metodu priimama lygi 0,01 auto/m.

Pradiniu laiko momentu TS greitis ir koncentracija visais modeliavimo atvejais yra vienoda - greitis visuose tarpiniuose mazguose lygus $5,55 \mathrm{~m} / \mathrm{s}$, o koncentracija 0,1 auto/m. 
Lyginant tarpusavyje du metodus pastebima jog sutelktujų parametru metodas prie ịvairių modeliavimo sąlygu dirba daug stabiliau ir visais modeliavimo atvejais pateikia panašius rezultatus.

Dujų kinetinis modelis labai jautriai reaguoja i pasikeitusias uždavinio kraštines sąlygas. Iš palygintų keturių atvejų matome jog 2 atvejuose iš 4 prie 230 ir 250 s modeliavimas buvo nutrauktas, nes TS parametru reikšmès šuoliškai pradejo artèti prie $\infty$. Metodui reikalingas ilgas pereinamasis laikotarpis kol, greičio ir koncentracijos reikšmès nusistovi ties pusiausvyros padètimi (raudona linija pateiktuose 3.21-3.24 paveiksluose). Metodas stabilus kai, kraštinès uždavinio sąlygos yra nutolusios nuo didžiausių leistinų uždavinio reikšmių. Esant tokiomsąlygom šiuo metodu galima įvertinti TS parametru pokyčius.

Sukurtas sutelktujų parametrų metodas stabilus prie įvairių kraštinių sąlygų, tačiau jo trūkumas yra tas, kad metodas dirba ties ribinèmis TS greičio ir koncentracijos reikšmėmis. Šị trūkumą galima pašalinti ị lygtis (2.34) ir (2.35) ivedant papildomas funkcijas $r_{\mathrm{k}, \text { in }}, r_{\mathrm{k}, \text { out }}, r_{\mathrm{v}, \text { in }}, r_{\mathrm{v}, \text { out }}$, kurios kinta priklausomai nuo TS greičio ir koncentracijos reikšmių. Funkcijų pobūdis disertacijoje nèra atskleistas dèl eksperimentinių duomenų trūkumo.

\subsection{Koncentruotụ parametrų metodo pritaikymas transporto srautams modeliuoti miesto tinkle}

Matematiškai modeliuojant transporto srautų tinklus 2 skyriuje aprašyti elementai jungiami i bendrą tinklą. Jungiant atskirus elementus tarpusavyje būtina nurodyti kelio atkarpų pirmo ir paskutinio taško kraštines sąlygas, kurios vidiniams gatvių tinklo sistemos taškams, tapatinamos su sankryžų kraštinèmis sąlygomis. Tiesios kelio atkarpos kraštinių elementu kraštiniai taškai kartu yra ir sankryžos elemento kraštiniai taškai, todèl tokie taškai tampa kritiniais perduodant ir paskirstant srautus visame tinkle.

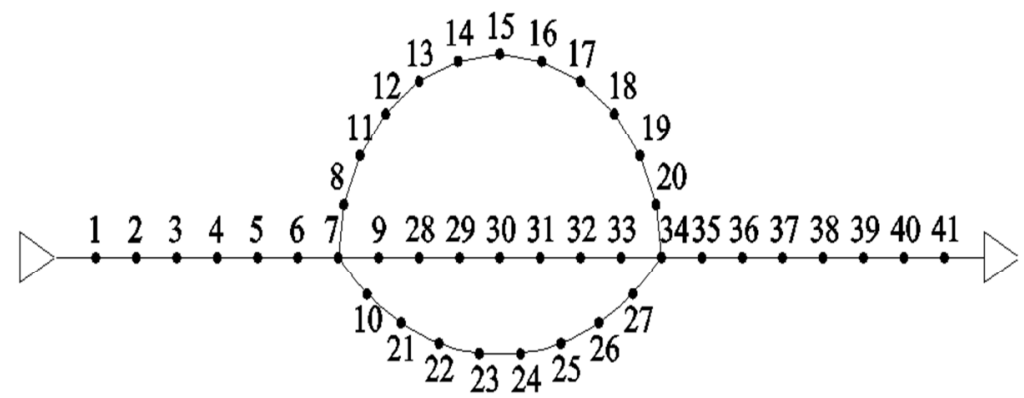

3.25 pav. Transporto srautų tinklo elementas

Fig 3.25. Traffic flow network 
Elementarus tokios sankryžos pavyzdys pateiktas 3.25 paveiksle Srautu tinklo elementas sudarytas iš penkių kelio atkarpų, kurios tarpusavyje sujungtos dviem sankryžom taškuose 7 ir 34 . Šiuose taškuose yra ivvestas automobilių transporto srautų valdymo algoritmas, kurio grafinis vaizdas pateiktas 3.26 ir 3.27 paveiksluose

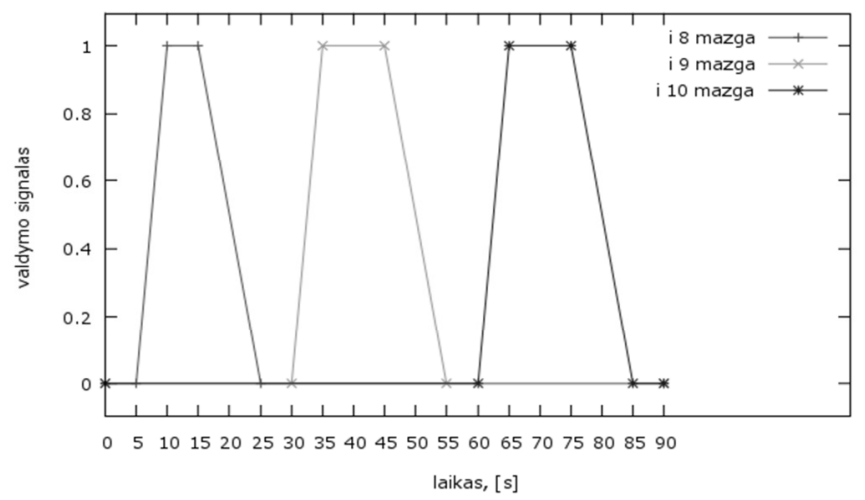

3.26 pav. Valdymo signalo sankryžoje (mazgas 7) algoritmas

Fig. 3.26. Algorythm of traffic control signal at point 7

Sankryžos valdymo signalas modelyje ịprastai yra imamas lygus 0 (raudonas šviesoforo signalas), o kai eismas pers sankryžos mazgą galimas valdymo signalas prilyginamas 1. Siekiant sumažinti staigius automobilių srauto parametru šuolius pasikeitus signalo reikšmei signalo pasikeitimo pradžioje ir pabaigoje i modeli ịvesta tiesiné laipsniškai didejjanti arba laipsniškai mažejanti signalo pasikeitimo funkcija, kuri 3.26 ir 3.27 paveiksluose atitinka nuožulnią tiesę.

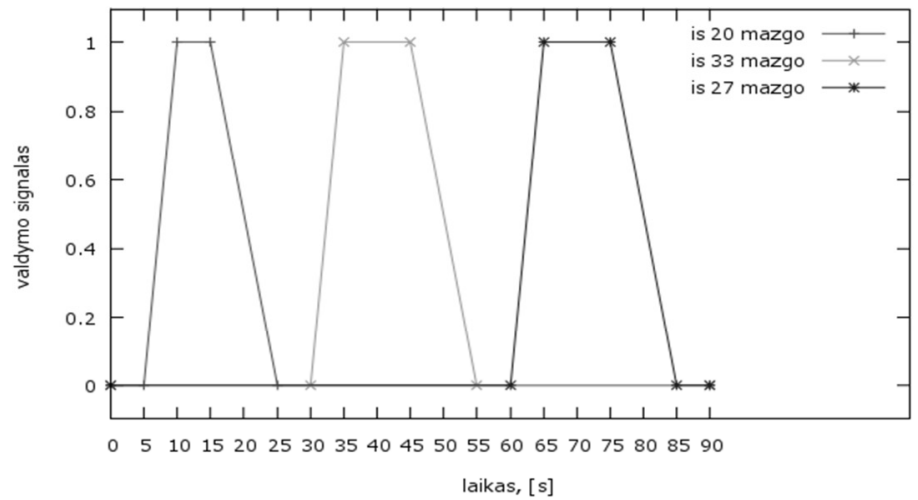

3.27 pav. Valdymo signalo sankryžoje (mazgas 34) algoritmas

Fig. 3.27. Algorythm of traffic control signal at point 34 
Vienu, tuo pačiu laiko momentu, sankryžos mazge 7 eismas galimas tik $\mathfrak{i}$ vieną iš išeinančiu eismo juostų. Mazge 34 tuo pačiu laiko momentu $\mathfrak{i}$ išeinančią eismo juostą transporto priemonès gali įvažiuoti tik iš vienos ieinančios eismo juostos.

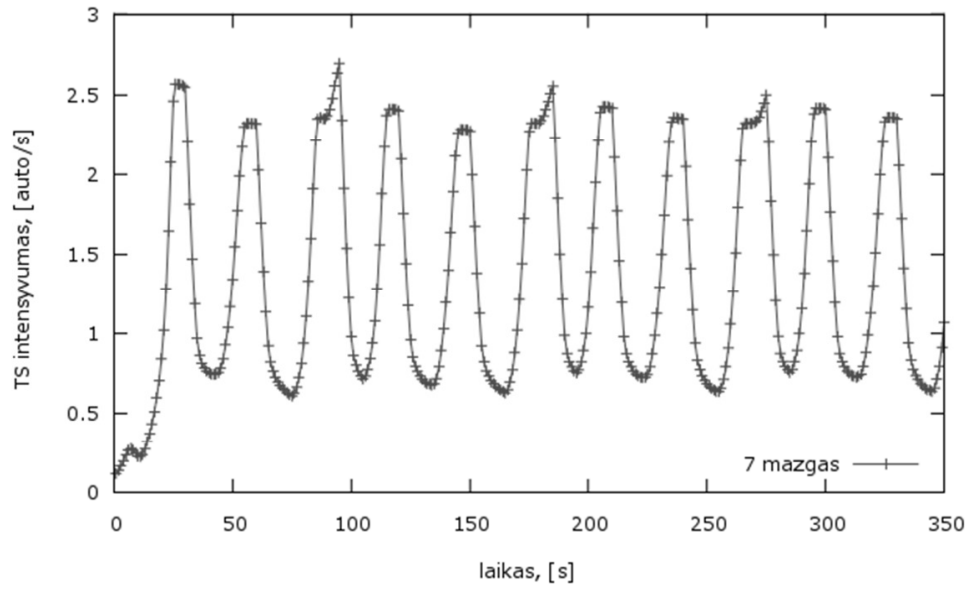

3.28 pav. Transporto srauto intensyvumo reikšmè mazge: 7

Fig 3.28. Traffic flow intensity at point 7

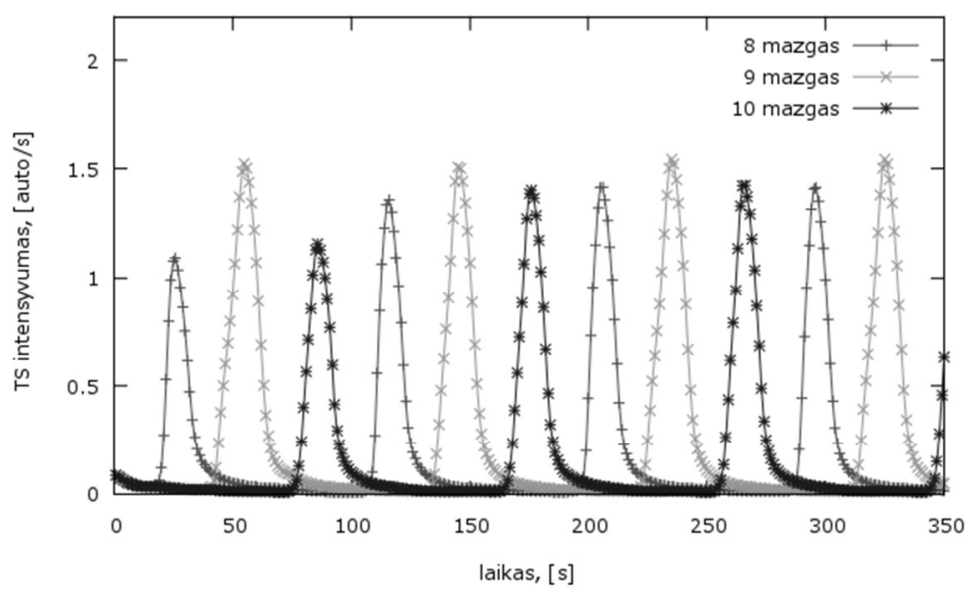

3.29 pav. Transporto srauto intensyvumo reikšmės mazguose: $8,9,10$

Fig 3.29. Traffic flow intensity at points $8,9,10$

Mazgai 1 ir 41 yra visos eismo juostų sistemos (tinklo) kraštiniai taškai, per kuriuos apkraunama tinklo pavidalo sistema. I sistemą naujos transporto priemonès patenka tik per mazgą Nr. 1, o iš sistemos išvažiuoti gali tik per mazgą Nr. 41. 
Prielaidos šiam modeliui sudaryti yra pateiktos 2.1. skyriuje. Kiekviename mazge užrašoma (2.34), (2.35) lygčių sistema ir ieškomi nežinomieji parametrai $k$ ir $v$. Transporto srauto intensyvumas randamas kaip šių parametrų sandauga.

Šios sistemos modeliavimo rezultatai pateikiami 3.28-3.39 paveiksluose, kai sistemos parametrai yra tokie:

$$
k_{\max }=0,2 \text { auto } / \mathrm{m} ; q_{\max }=2,776 \text { auto } / \mathrm{s} ; v_{\max }=13,38 \mathrm{~m} / \mathrm{s} .
$$

Kraštiniuose mazguose, 1 ir 41, ịvedamos tokios parametrų reikšmès:

$q_{1}=0,1$ auto $/ \mathrm{s} ; v_{1}=10,0 \mathrm{~m} / \mathrm{s} ; q_{41}=0,1$ auto $/ \mathrm{s} ; v_{41}=10,0 \mathrm{~m} / \mathrm{s}$.

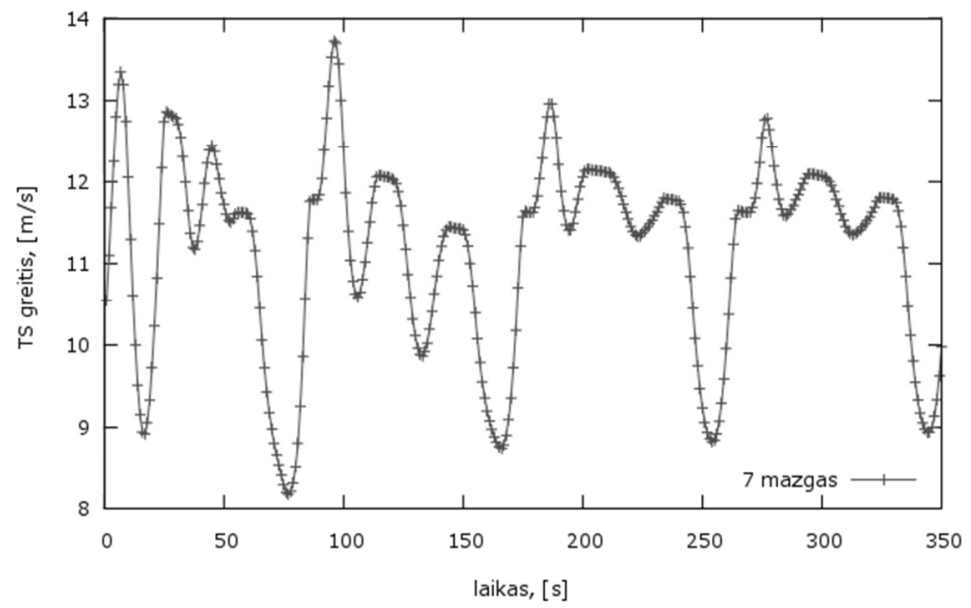

3.30 pav. Transporto srauto greičio reikšmė mazge: 7

Fig. 3.30. Traffic flow speed at point 7

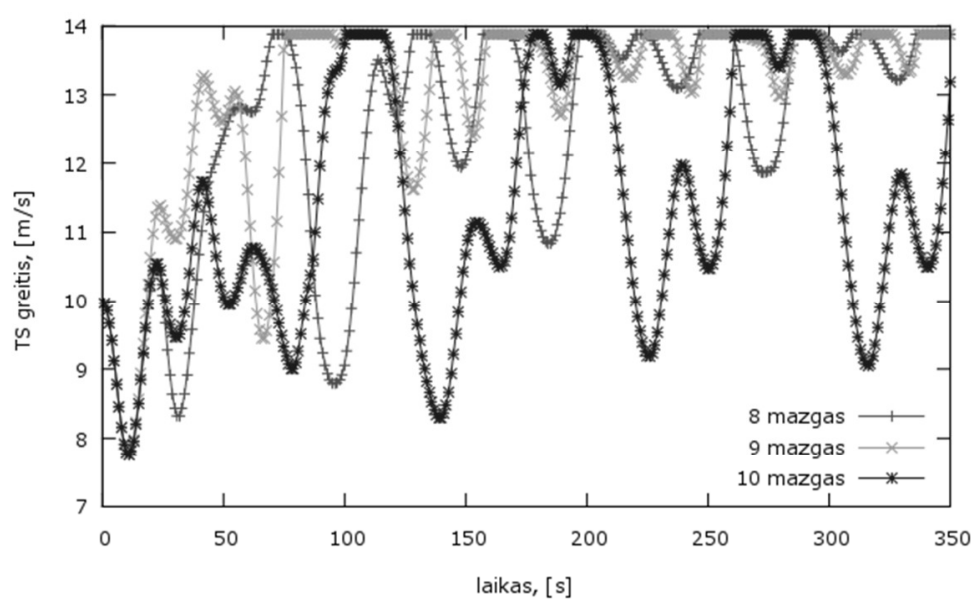

3.31 pav. Transporto srauto greičio reikšmès mazguose: $8,9,10$

Fig. 3.31. Traffic flow speed at points 8, 9, 10 
Transporto srauto intensyvumas 7 mazge yra didesnis už TS intensyvumus išeinančiuose kelio atkarpose. 7 mazge srauto intensyvumas neviršija užduotos didžiausios leistinos reikšmès $q_{\max }=2,776$ auto/s.

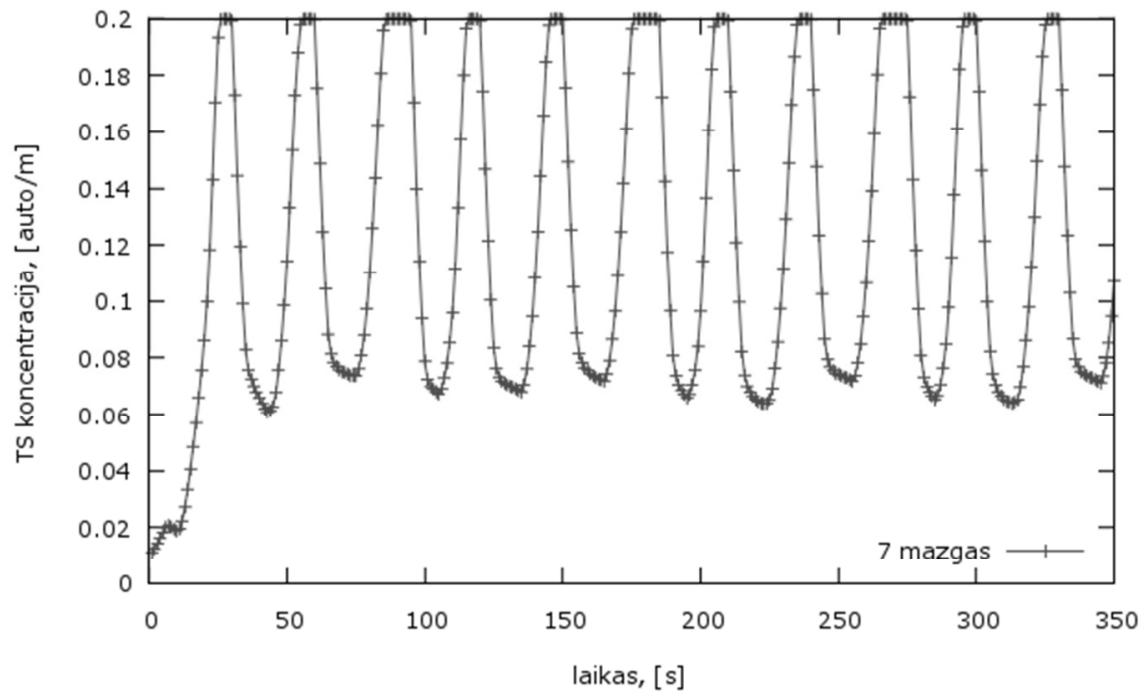

3.32 pav. Transporto srauto koncentracijos reikšmè mazge: 7

Fig. 3.32. Traffic flow concentration at points 7

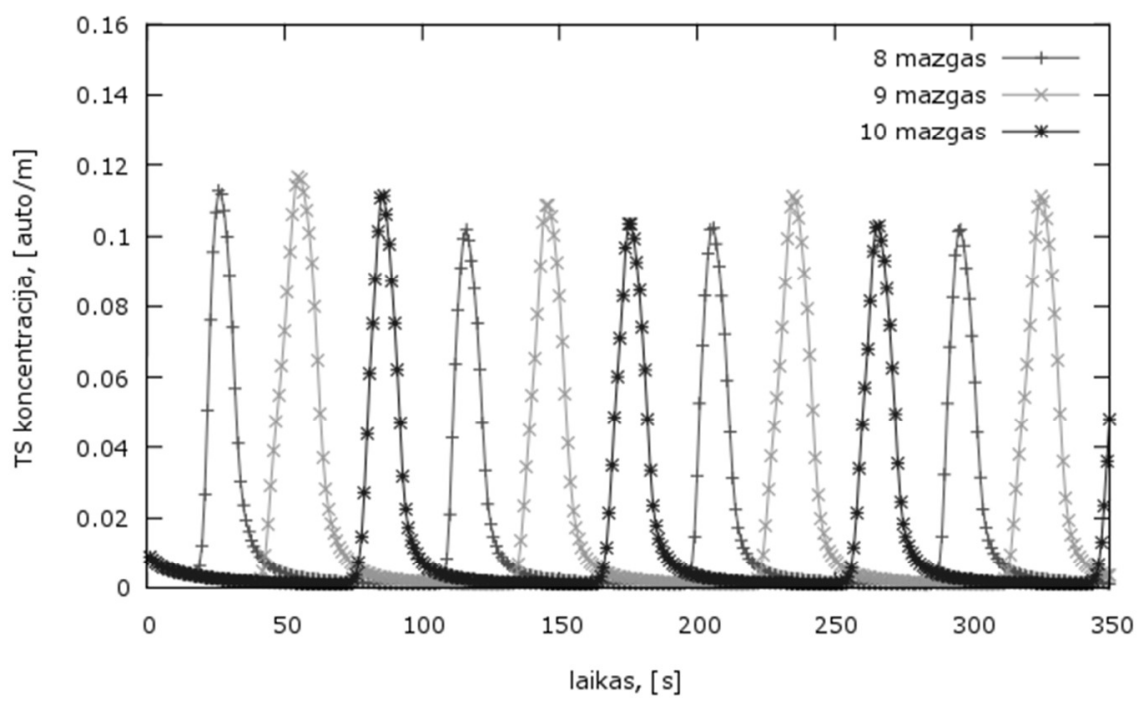

3.33 pav. Transporto srauto koncentracijos reikšmès mazguose: $8,9,10$

Fig. 3.33. Traffic flow concentration at points 8, 9, 10 


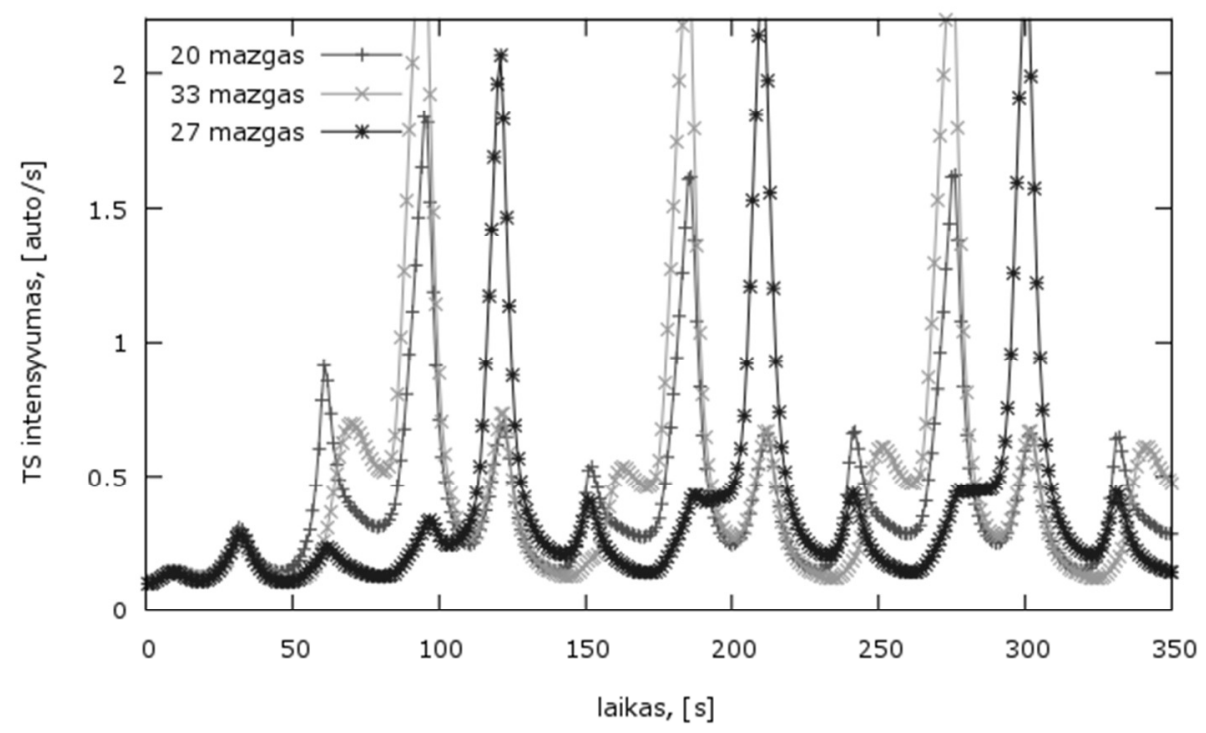

3.34 pav. Transporto srauto intensyvumo reikšmės mazguose: 20, 27, 33

Fig. 3.34. Traffic flow intensity at points $20,27,33$

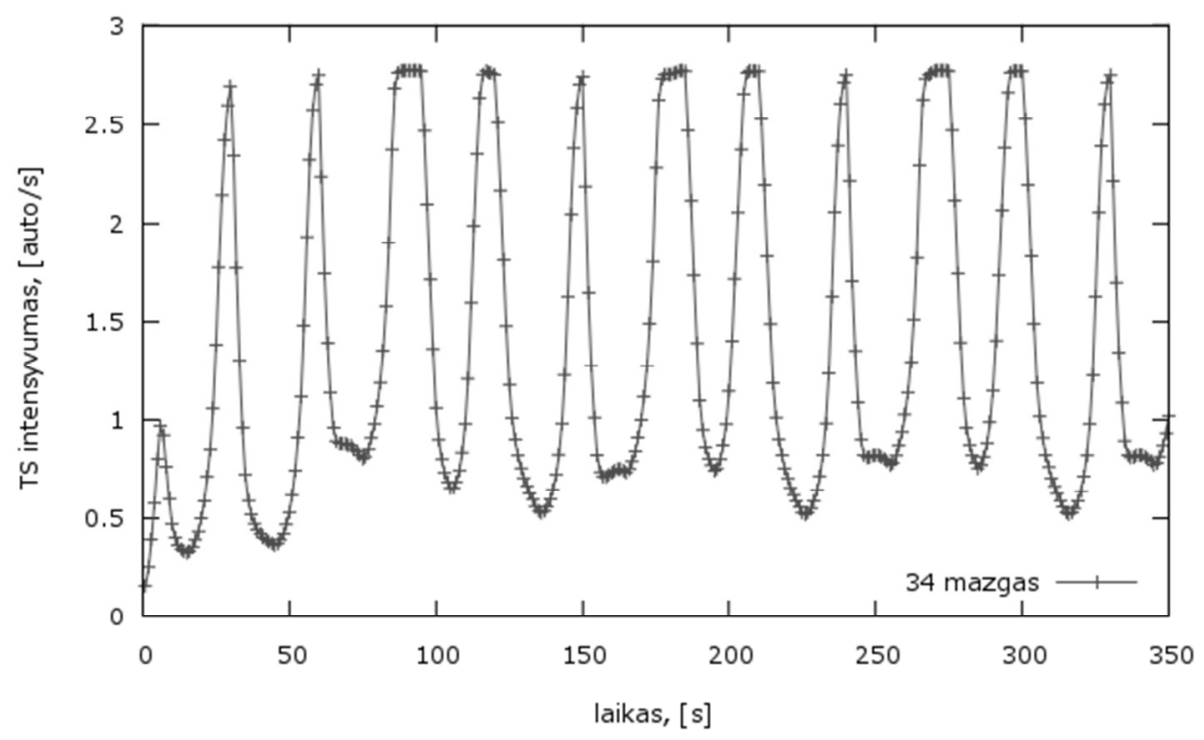

3.35 pav. Transporto srauto intensyvumo reikšmè mazge: 34

Fig. 3.35. Traffic flow intensity at point 34 


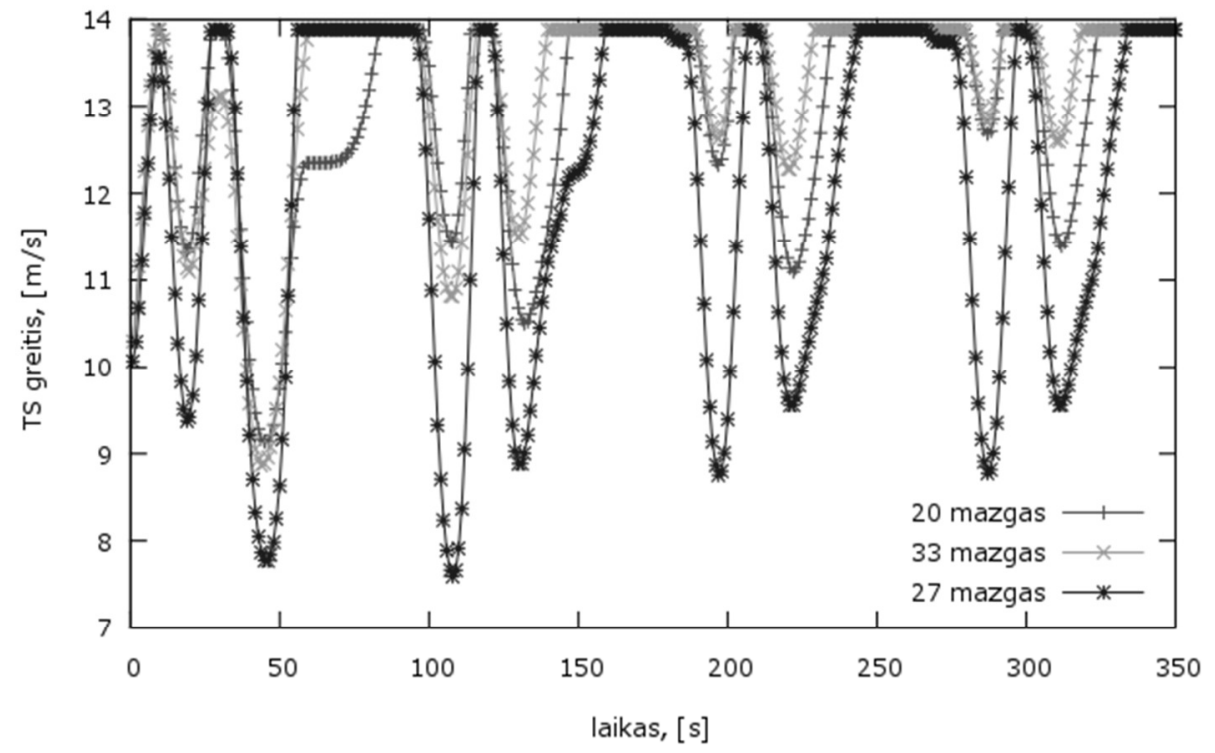

3.36 pav. Transporto srauto greičio reikšmès mazguose: 20, 27, 33

Fig. 3.36. Traffic flow speed at points 20,27, 33

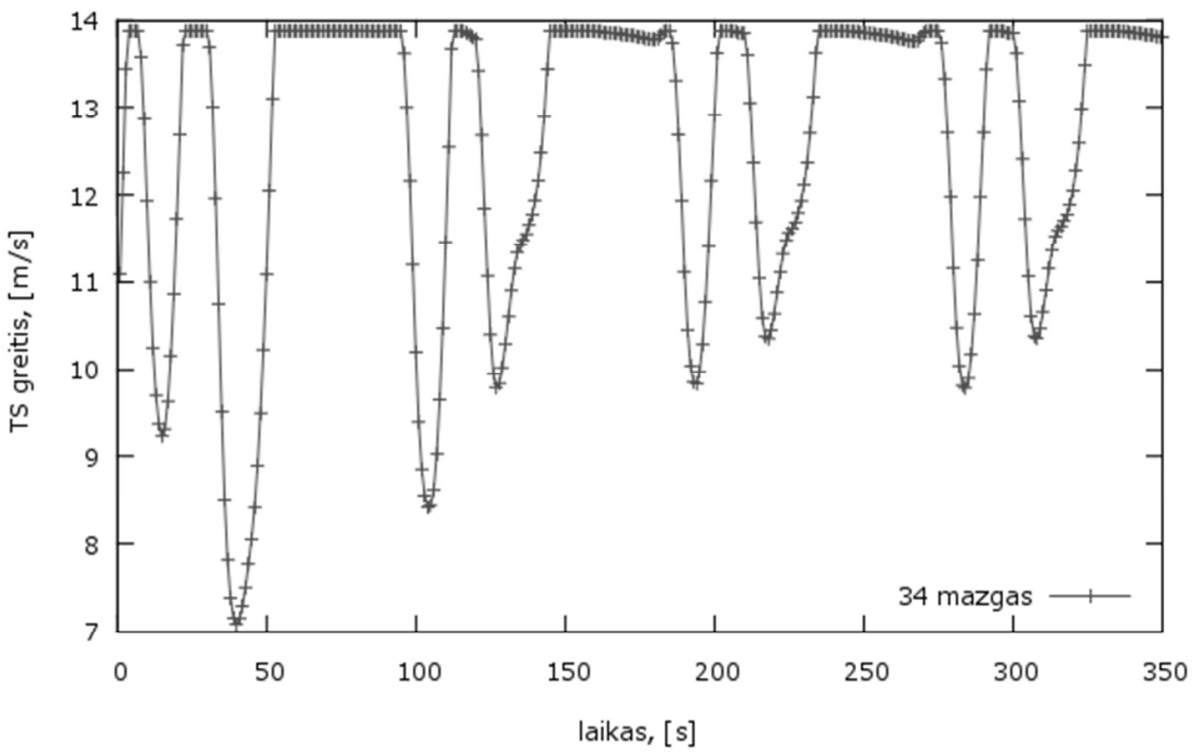

3.37 pav. Transporto srauto greičio reikšmè mazge: 34

Fig. 3.37. Traffic flow speed at point 34 


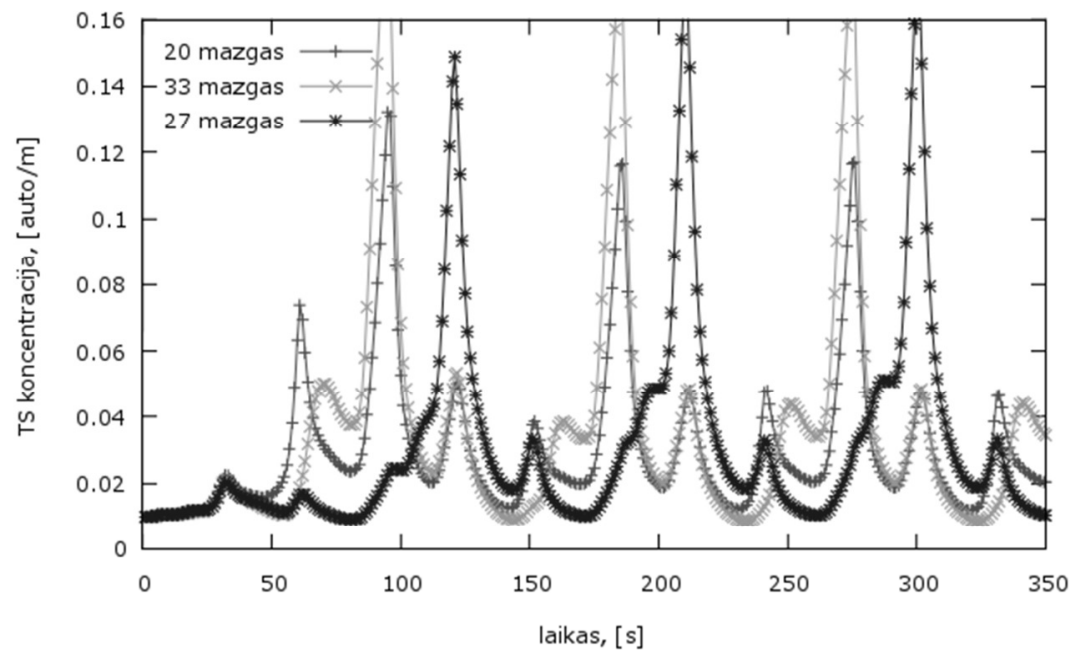

3.38 pav. Transporto srauto koncentracijos reikšmės mazguose: $20,27,33$

Fig. 3.38. Traffic flow concentration at points $20,27,33$

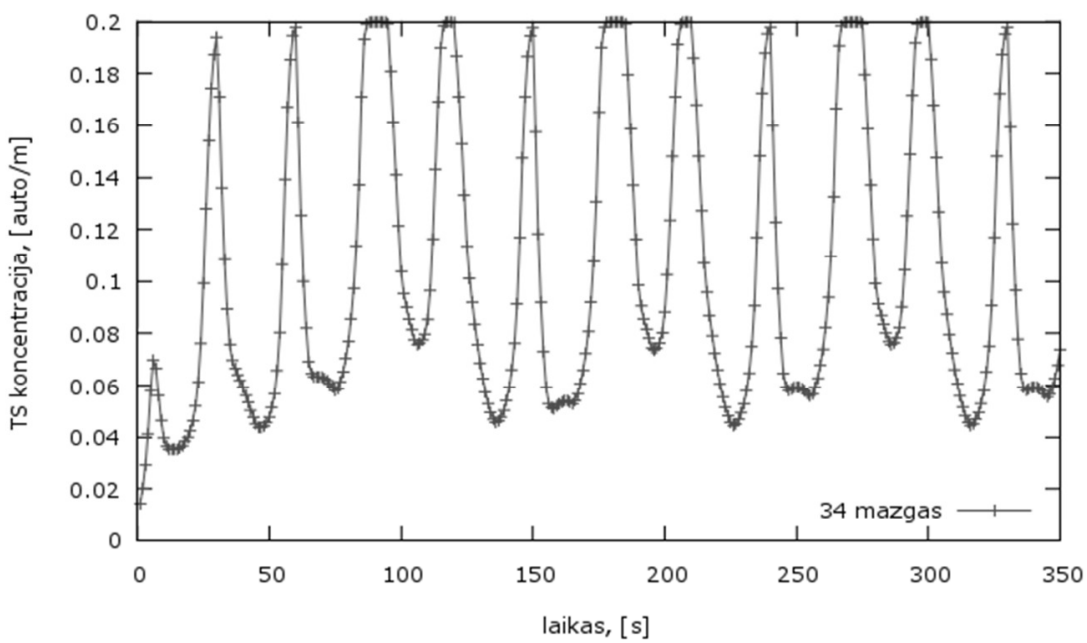

3.39 pav. Transporto srauto koncentracijos reikšmė mazge: 34

Fig. 3.39. Traffic flow concentration at point 34

Transporto srauto greitis 34 mazge, įeinančiame kelyje, yra mažesnis už TS greičius išeinančiuose keliuose. Toks rezultatas gaunamas, kadangi išeinančiose kelio atkarpose yra mažiau automobilių. TS greitis neviršija didžiausios leistinos reikšmès. TS koncentracijos reikšmés atkaroja gautus TS greičio rezultatus. 7 mazgas yra labiausiai apkrautas ir periodiškai pasiekia didžiausią leistiną 
koncentracijos reikšmę - pilnai užsipildo kai šviesoforo signalas būna raudonos spalvos. Iš 3.32 paveikslo matome, kad kas trečias kreivès pikas yra ilgesnis ir kinta nuo 0,06 iki maždaug 0,076 auto/m.

Šis rezultatas atspindi pasirinktą signalo algoritmą. Pagal algoritmą, kas trečias signalas yra trumpesnis, 3.27 paveikslas. Transporto srauto koncentracijos reikšmès neviršija užduotų didžiausių leistinų koncentracijos reikšmių.

Išeinančiame, 34 mazge, TS parametrų kitimas yra analogiškas 7 mazgui. Tik čia stebimas priešingas reiškinys - įeina trys keliai, o išeina vienas.

\subsection{Trečio skyriaus išvados}

1. Sprendžiant dujų kinetinès teorijos pagrindu sudaryto modelio lygtis charakteristikų metodu, sprendinys labai jautriai reaguoja ị pasikeitusias uždavinio kraštines sąlygas, žiūrèti 3.1-3.6 paveikslus.

2. Sprendžiant sukurto universalaus modelio lygtis ryškios priklausomybès nuo kraštiniu sąlygų nepastebèta, tačiau sprendinys labai greitai artejja prie ribiniu nežinomojo reikšmiu - max arba min galimos koncentracijos arba greičio reikšmès, žiūrèti 3.11-3.16 paveikslus. 


\section{4}

\section{Matematinio modelio rezultaty ir eksperimentinių duomenų palyginimas. Modelio pritaikymo galimybès}

\subsection{Modeliavimo rezultatų ir eksperimentinių duomenų palyginimas}

Šio skyriaus medžiaga buvo publikuota straipsnyje: Junevičius et al. (2011).

Šiame skyriuje pateikiamas transporto srautụ matavimo būdų palyginimas. Matuojant pirmu būdu tam tikrame eismo juostos taške yra pastatoma matavimo iranga. Šios irrangos pagalba visą parą yra fiksuojamas TS intensyvumas ir greitis šiame kelio taške, užfiksuotus parodymus ịrašant kas $90 \mathrm{~s}$.

4.1 paveiksle grafiškai pateikiamos išmatuotos transporto srauto intensyvumo reikšmès, o 4.3 paveiksle grafiškai pateikiamos transporto srauto greičio reikšmès.

Šie, išmatuoti duomenys, paruošiami modeliavimui ir naudojami tikrinant kaip modelis atkartoja tam tikrą funkciją, kuri yra gauta iš natūrinių bandymų. 


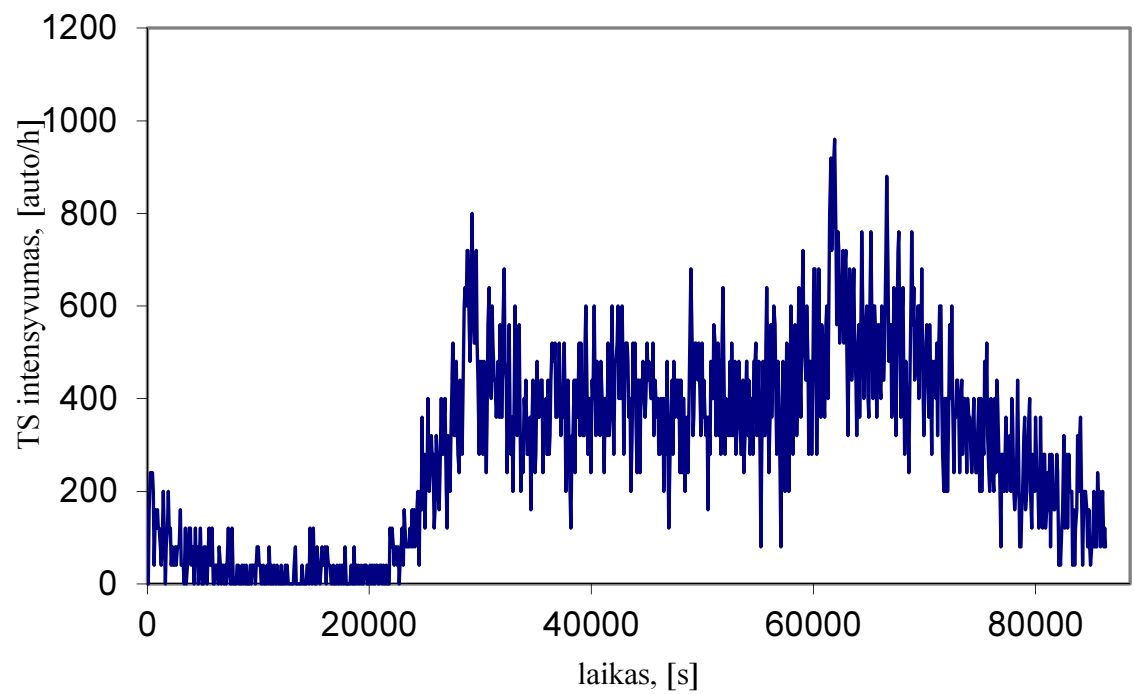

4.1 pav. Transporto srauto intensyvumo pasiskirstymo grafikas išmatuotas fiksuotame kelio taške per viena para

Fig. 4.1. Traffic flow intensity measured at fixed road point during one day

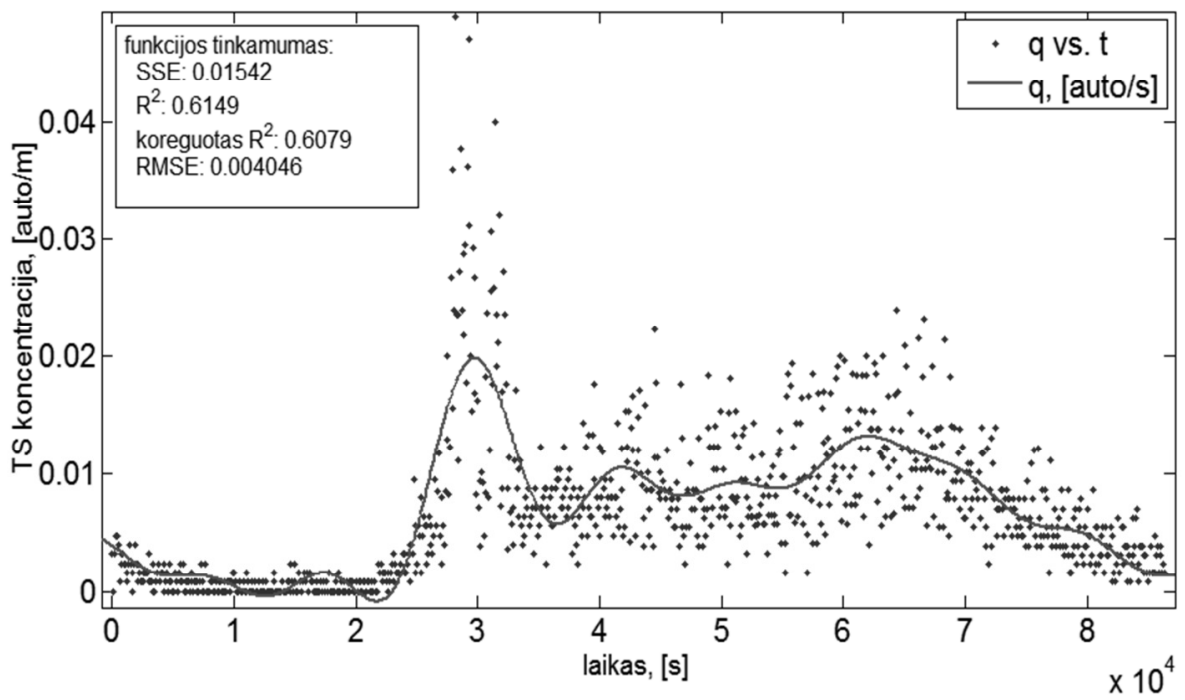

4.2 pav. Transporto srauto koncentracijos pasiskirstymo grafikas per viena parą. Gautas iš 4.1 paveikslo duomenų gauta naudojant Furje skirstinį iki aštunto nario Fig. 4.2. Traffic flow concentration at fixed road point during one day approximated using Furje distribution 
Transporto srauto koncentracijos pokyčio nuo laiko funkcija gauta panaudojant Furje eilute iki aštunto nario išskleistą lygti:

$$
\begin{aligned}
& k(t=) 6,691-3,171 \cos \left(7,469 \cdot 10^{-5} \cdot t\right)-4,12 \sin \left(7,469 \cdot 10^{-5} \cdot t\right)_{-} \\
& -0,6632 \cos \left(7,469 \cdot 10^{-5} \cdot t \cdot 2\right)-2,079 \sin \left(7,469 \cdot 10^{-5} \cdot t \cdot 2\right)_{+} \\
& +0,2104 \cos \left(7,469 \cdot 10^{-5} \cdot t \cdot 3\right)+1,132 \sin \left(7,469 \cdot 10^{-5} \cdot t \cdot 3\right)_{-} \\
& -0,07613 \cos \left(7,469 \cdot 10^{-5} \cdot t \cdot 4\right)+0,501 \sin \left(7,469 \cdot 10^{-5} \cdot t \cdot 4\right)_{+} \\
& +0,02355 \cos \left(7,469 \cdot 10^{-5} \cdot t \cdot 5\right)-1,007 \sin \left(7,469 \cdot 10^{-5} \cdot t \cdot 5\right)_{+} \\
& +0,4324 \cos \left(7,469 \cdot 10^{-5} \cdot t \cdot 6\right)+0,2423 \sin \left(7,469 \cdot 10^{-5} \cdot t \cdot 2\right)_{-} \\
& -0,292 \cos \left(7,469 \cdot 10^{-5} \cdot t \cdot 7\right)+0,3163 \sin \left(7,469 \cdot 10^{-5} \cdot t \cdot 7\right)_{+} \\
& +0,111 \cos \left(7,469 \cdot 10^{-5} \cdot t \cdot 8\right)-0,4374 \sin \left(7,469 \cdot 10^{-5} \cdot t \cdot 8\right)
\end{aligned}
$$

Transporto srauto greičio pokyčio nuo laiko funkcija gauta panaudojant Furje eilute iki aštunto nario išskleistą lygtị:

$$
\begin{aligned}
& v(t)=13,01+0,7436 \cos \left(9,301 \cdot 10^{-5} \cdot t\right)+0,2321 \sin \left(9,301 \cdot 10^{-5} \cdot t\right)- \\
& -0,6528 \cos \left(9,301 \cdot 10^{-5} \cdot t \cdot 2\right)+0,8327 \sin \left(9,301 \cdot 10^{-5} \cdot t \cdot 2\right)_{+} \\
& +0,3694 \cos \left(9,301 \cdot 10^{-5} \cdot t \cdot 3\right)-0,6593 \sin \left(9,301 \cdot 10^{-5} \cdot t \cdot 3\right)_{+} \\
& +0,06888 \cos \left(9,301 \cdot 10^{-5} \cdot t \cdot 4\right)+0,7916 \sin \left(9,301 \cdot 10^{-5} \cdot t \cdot 4\right)_{-} \\
& -0,3644 \cos \left(9,301 \cdot 10^{-5} \cdot t \cdot 5\right)-0,7338 \sin \left(9,301 \cdot 10^{-5} \cdot t \cdot 5\right)_{+} \\
& +0,2995 \cos \left(9,301 \cdot 10^{-5} \cdot t \cdot 6\right)+0,5672 \sin \left(9,301 \cdot 10^{-5} \cdot t \cdot 6\right)_{-} \\
& -0,48 \cos \left(9,301 \cdot 10^{-5} \cdot t \cdot 7\right)-0,1453 \sin \left(9,301 \cdot 10^{-5} \cdot t \cdot 7\right)_{+} \\
& +0,2846 \cos \left(9,301 \cdot 10^{-5} \cdot t \cdot 8\right)+0,1417 \sin \left(9,301 \cdot 10^{-5} \cdot t \cdot 8\right) .
\end{aligned}
$$

Gautos TS greičio ir koncentracijos funkcijos, kintančios nuo laiko, naudojamos modeliuojant tiesią kelio atkarpą sukurtu sutelktujų parametrų metodu.

Matematinis modelis sudarytas pasinaudojant prielaidomis pateiktomis skyriuje 2. Modeliavimui imama tiesi, $100 \mathrm{~m}$ ilgio kelio atkarpa, kurios galuose ivedamos kraštinès uždavinio sąlygos. Modeliuojamas kelio ruožas yra padalintas i 6 atkarpas. Mazguose 1 ir 7 yra ịvestos uždavinio kraštinès sąlygos.

Didžiausias leistinas greitis yra $15 \mathrm{~m} / \mathrm{s}$. Pradiniu laiko momentu visuose kelio mazguose, išskyrus kraštinius, koncentracija buvo lygi 0,01 auto/m, o greitis $1 \mathrm{~m} / \mathrm{s}$.

Kaip matyti iš 4.1 ir 4.3 grafikų išmatuota koncentracijos reikšmè visą para yra nedidele ir TS, net ir piko, valandomis nepriarteja prie didžiausios galimos reikšmès, todèl srauto greitis lygus didžiausiam galimam greičiui - $15 \mathrm{~m} / \mathrm{s}$. 
Kelio atkarpos galuose ivestos matavimais paremtos srauto koncentracijos ir greičio funkcijos, o vidiniuose kelio mazguose gaunamos mažesnès apskaičiuotos koncentracijos reikšmès, bet kitimo pobūdis yra artimas įvestos funkcijos kitimui, funkcija dalinai atkartojama.

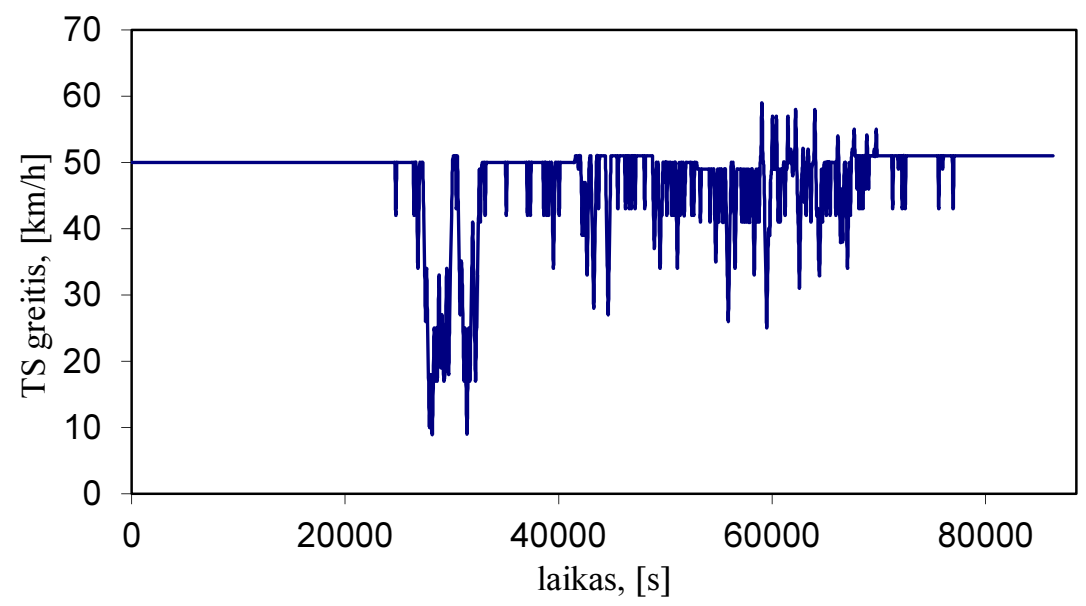

4.3 pav. Transporto srauto greičio pasiskirstymo grafikas išmatuotas per vieną parą

Fig. 4.3. Traffic flow speed measured at fixed road point during one day

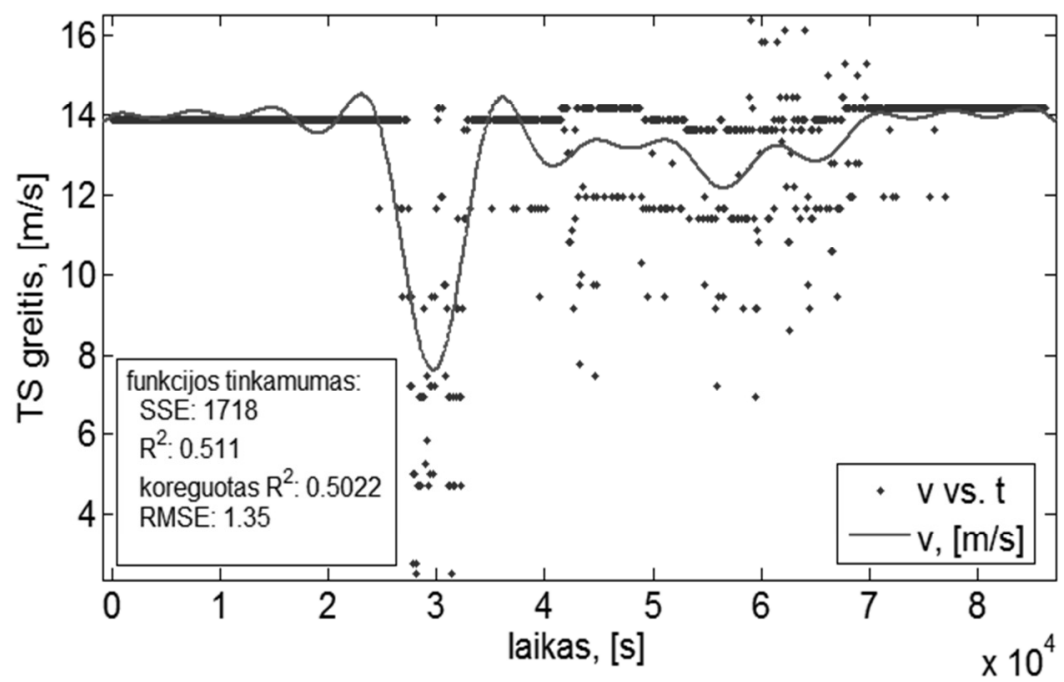

4.4 pav. Automobilių srauto greičio pasiskirstymo grafikas per vieną parą. Gautas iš 4.3 paveikslo duomenų naudojant Furje skirstinị iki aštunto nario

Fig. 4.4. Traffic flow speed at fixed road point during one day approximated using Furje distribution 
Greičio reikšmès visą modeliavimo laikotarpi išlieka ties didžiausia galima reikšme ir nekinta. Taip yra todèl, kad kraštiniuose mazguose ịvestos koncentracijos reikšmès yra mažos ir neviršija 0,015 auto/m.

Patikslinus antrame skyriuje aprašytas funkcijas $r_{\mathrm{k}, \text { in }}, r_{\mathrm{k}, \mathrm{ou}}, r_{\mathrm{v}, \mathrm{in}}, r_{\mathrm{v}, \text { out }}$ galima gauti didesnio tikslumo modeliavimo rezultatus. Šių funkcijų kitimo pobūdis nèra galutinai nustatytas dèl eksperimentinių duomenų trūkumo.

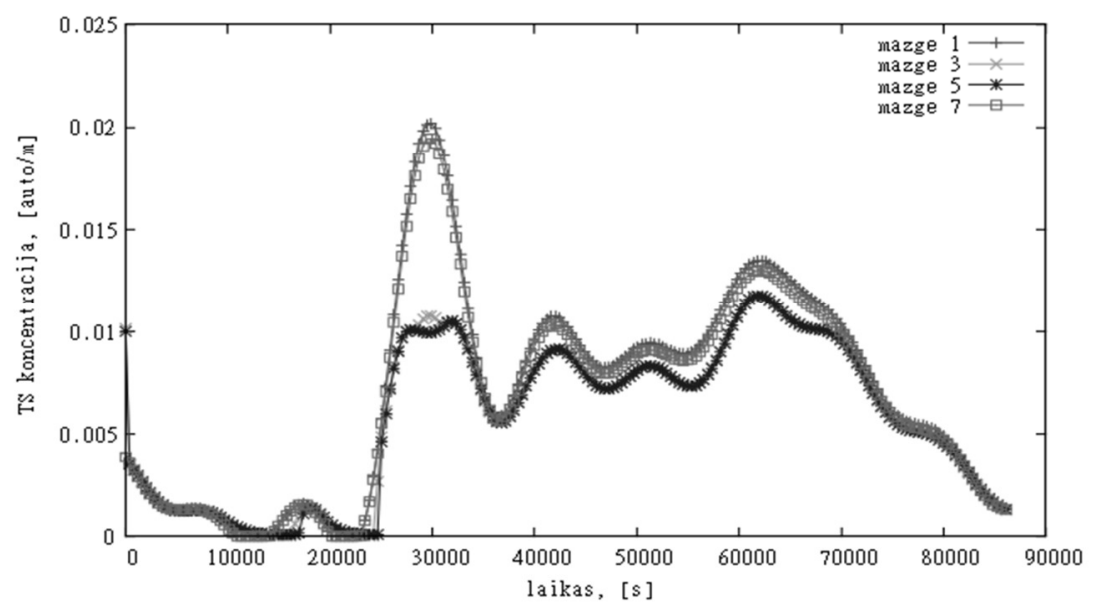

4.5 pav. Sumodeliuotos TS koncentracijos reikšmès 1, 3, 5, 7 mazguose, kai 1-me ir 7-me mazguose ịvestos gautos $v(t)$ ir $k(t)$ lygtys

Fig. 4.5. Modeling results of traffic flow concentration at points 1, 3, 5, 7 when approximated parameters $v(t)$ and $k(t)$ are inserted at points 1 and 7

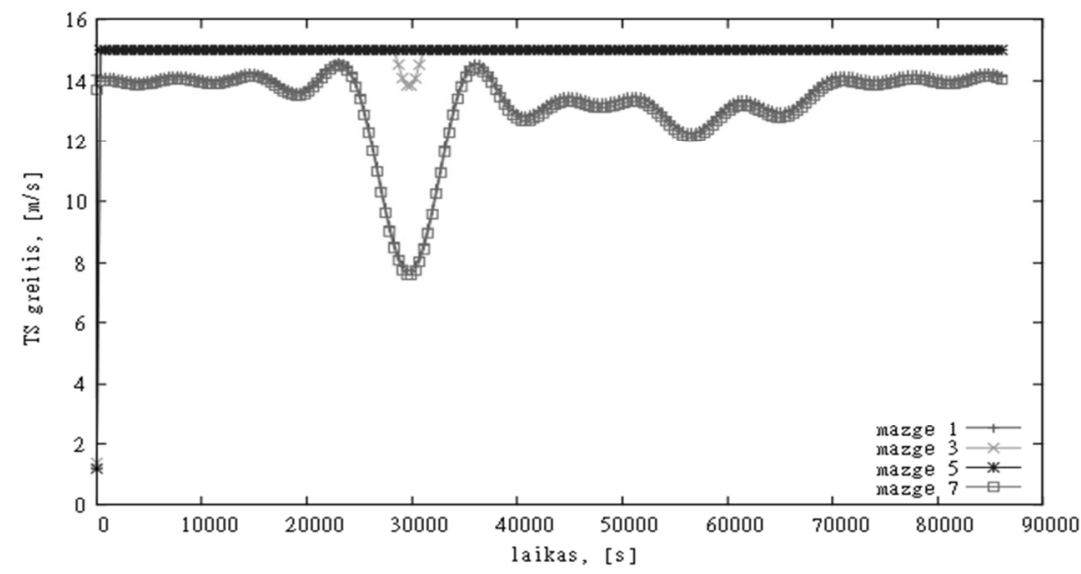

4.6 pav. Sumodeliuotos TS greičio reikšmès 1, 3, 5, 7 mazguose, kai 1-me ir 7-me mazguose ịvestos gautos $v(t)$ ir $k(t)$ lygtys

Fig. 4.6. Modeling results of traffic flow speed at points $1,3,5,7$ when approximated parameters $v(t)$ and $k(t)$ are inserted at points 1 and 7 


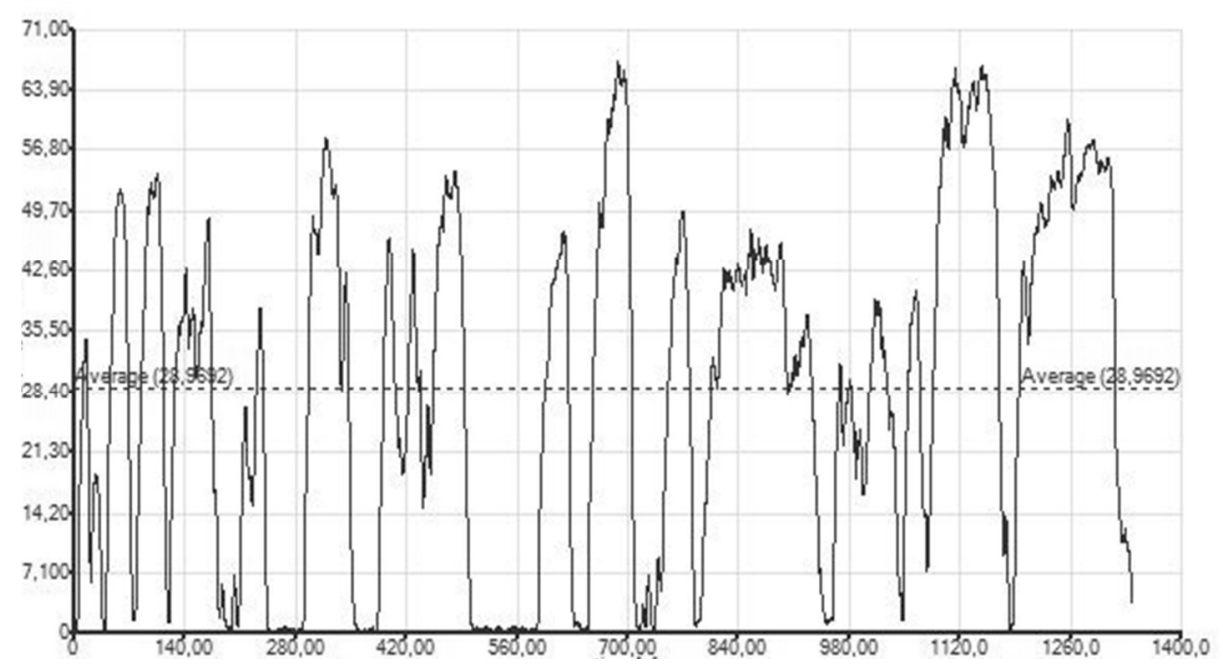

4.7 pav. Automobilio, judančio transporto sraute, greičio pasiskirstymo pagal laiką grafikas išmatuotas automobiliu atlikus bandomaji važiavimą užsiduotu maršrutu

Fig. 4.7. Traffic flow speed measured using car with measuring device

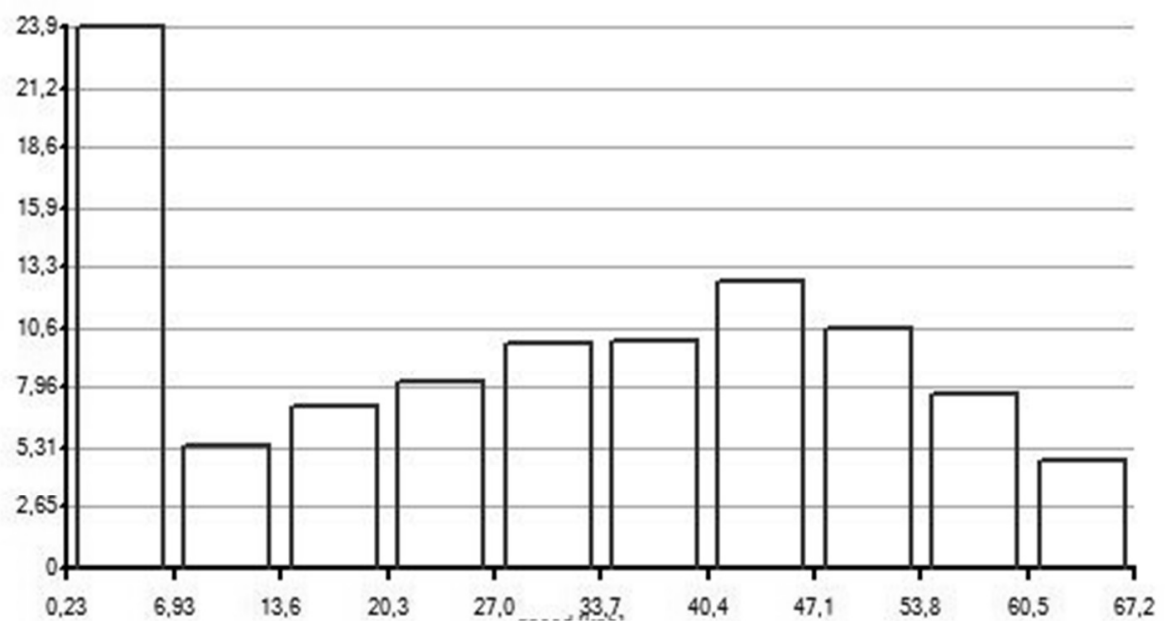

4.8 pav. Automobilio, judančio transporto sraute, greičio pasiskirstymo histograma Matavimas atliktas automobiliu atlikus bandomaji važiavimą užsiduotu maršrutu

Fig. 4.8. Traffic flow speed distribution measured using car with measuring device

Antruoju būdu transporto srautas matuojamas važiuojant automobiliu kuriame sumontuota įranga leidžianti išmatuoti automobilio dinamines charakteristikas. Matuojant šiuo būdu priimama prielaida jog automobilio 
judejjimo greitis yra lygus TS vidutiniam greičiui. Matuojant šiuo būdu išmatuojamas tik vienas parametras - TS greitis.

Eksperimento metu automobilis važiavo miesto gatvèmis ne piko metu. Automobilio greičio matavimai buvo atliekami prietaisu Data Loger DL1. Matavimai įrašomi $100 \mathrm{~Hz}$ dažniu. Juo buvo matuojamas automobilio greitis, nuvažiuotas atstumas, laikas. Gauti matavimai prilyginami srauto parametrams, kadangi automobilis yra srauto dalyvis. Iš eksperimentinių duomenų Paveiksluose 4.7 ir 4.8 matome jog automobilių srauto greitis mieste vidutiniškai sudaro $20-30 \mathrm{~km} / \mathrm{h}$ ir apie $20-25 \%$ viso važiavimo laiko automobilis praleidžia stovèdamas prie šviesoforų. Piko metu tai gali sudaryti $50 \%$ ir daigiau.

Lyginat empirinius duomenis gautus išmatavus srauto parametrus fiksuotame kelio mazge matome šiokius tokius neatitikimus. Čia srauto greitis siektu apie $40 \mathrm{~km} / \mathrm{h}$. Śiuo metodu atliekant matavimus paveiksluose $4.1,4.2,4.3$ ir 4.4 pateikiami apibendrinti greičio ir srauto intensyvumo parametrai, nes matavimas atliekamas 90 s ir po to užrašoma apibendrinta rauto parametrų vertè.

Lyginant eksperimentinius ir modeliavimo rezultatus pastebima ir atitikimų ir skirtumų: pvz. matuojant srauto intensyvumą fiksuotame eismo juostos mazge skirtinguose kelio mazguose gauti duomenys skiriasi iki kelių kartu. Paskaičiuotas srauto intensyvumas gali siekti 2-2,5 auto/s, o išmatuotas 0,2 . Šie skirtumai gali kisti priklausomai nuo matavimo vietos ir matavimo trukmès. Jeigu matavimai atlikti ne piko metu išmatuotos srauto intensyvumo reikšmès yra mažos. Srauto greitis ir jo kitimas laike yra panašūs.

\subsection{Vidaus degimo variklio generuojamos emisijos modeliavimas tiesioje kelio atkarpoje pasitelkiant transporto sraytų matematinius modelius}

Automobilių deginių modeliavimas yra sudètingas. Autoriai Mansha et all. 2010 ir Descombes et all. 2003 detaliai nagrinejja procesus vykstančius vidaus degimo variklio degimo kameroje. Straipsniuose pateikiami programiniai paketai degimo procesams modeliuoti, taip pat iš straipsnių matosi, kad degimo procesų modeliavimas sudetingas ir turi daug atsitiktinių parametrų kurie gali itakoti modeliavimo rezultatą. Variklių emisijoms aprašyti naudojami eksperimentiniai duomenys pateikti 1 lentelèje. Duomenys paimti iš dokumento ÚTMUTATÓ a külterületi közúthálózati fejlesztések költség-haszon vizsgálatához II. külső hatások Gazdasági és Közlekedési Minisztérium Hálózati Infrastruktúra Főosztály 2006 GUIDE the suburban road network development cost-benefit test. II. external influences. Ministry of Economy and Transport Network Infrastructure Department 2006 Pagal VI „Regitra“ 
pateikiamus statistinius duomenis Lietuvoje registruotų motorinių transporto priemonių skaičiai yra pateikti 2 lenteleje.

1 lentelè. Automobilių variklių deginių emisijos priklausomybès nuo automobilių judejjimo greičio

Table 1. Automobile engine emissions dependences on vehicles' movement speed

(ÚTMUTATÓ a külterületi közúthálózati fejlesztések költség-haszon vizsgálatához II. külső hatások )

\begin{tabular}{|c|c|c|c|c|c|c|c|c|c|c|c|}
\hline \multirow{3}{*}{$\begin{array}{c}\text { greitis, } \\
\mathrm{km} / \mathrm{h}\end{array}$} & \multirow{3}{*}{$\begin{array}{c}\text { Emisijos } \\
\text { matavimo } \\
\text { vienetai }\end{array}$} & \multicolumn{5}{|c|}{ Lengvieji automobiliai } & \multicolumn{5}{|c|}{ Sunkvežimiai } \\
\hline & & \multicolumn{10}{|c|}{ emisijos $2010 \mathrm{~m}$. - prognozè pagal $2005 \mathrm{~m}$. duomenis } \\
\hline & & $\mathrm{CO}$ & $\mathrm{CH}$ & $\mathrm{NO}_{\mathrm{x}}$ & PM & $\mathrm{CO}_{2}$ & $\mathrm{CO}$ & $\mathrm{CH}$ & $\mathrm{NO}_{\mathrm{x}}$ & PM & $\mathrm{CO}_{2}$ \\
\hline 0 & $\mathrm{~g} / \mathrm{h}$ & 69,5 & 4,975 & 2,11 & 0,357 & 1554 & 61,0 & 7,80 & 21,35 & 1,98 & 6631,5 \\
\hline 5 & $\mathrm{~g} / \mathrm{km}$ & 13,90 & 0,995 & 0,422 & 0,0714 & 310,8 & 12,20 & 1,560 & 4,27 & 0,396 & 1326,3 \\
\hline 10 & $\mathrm{~g} / \mathrm{km}$ & 11,00 & 0,900 & 0,416 & 0,0597 & 262,7 & 10,20 & 0,611 & 3,84 & 0,321 & 1040,0 \\
\hline 20 & $\mathrm{~g} / \mathrm{km}$ & 7,12 & 0,714 & 0,394 & 0,0439 & 203,0 & 7,46 & 0,423 & 3,13 & 0,250 & 808,7 \\
\hline 30 & $\mathrm{~g} / \mathrm{km}$ & 5,33 & 0,590 & 0,405 & 0,0351 & 171,7 & 5,86 & 0,285 & 2,83 & 0,221 & 716,5 \\
\hline 40 & $\mathrm{~g} / \mathrm{km}$ & 3,97 & 0,435 & 0,411 & 0,0292 & 154,9 & 4,96 & 0,209 & 2,76 & 0,206 & 658,3 \\
\hline 50 & $\mathrm{~g} / \mathrm{km}$ & 3,14 & 0,418 & 0,427 & 0,0255 & 148,0 & 4,18 & 0,166 & 2,73 & 0,195 & 635,6 \\
\hline 60 & $\mathrm{~g} / \mathrm{km}$ & 2,37 & 0,416 & 0,486 & 0,0247 & 147,4 & 3,70 & 0,140 & 2,86 & 0,194 & 633,1 \\
\hline 70 & $\mathrm{~g} / \mathrm{km}$ & 1,72 & 0,392 & 0,556 & 0,0249 & 151,0 & 3,18 & 0,125 & 3,13 & 0,191 & 660,2 \\
\hline 80 & $\mathrm{~g} / \mathrm{km}$ & 1,52 & 0,379 & 0,623 & 0,0263 & 156,5 & 2,78 & 0,124 & 3,55 & 0,201 & 719,4 \\
\hline 90 & $\mathrm{~g} / \mathrm{km}$ & 1,76 & 0,418 & 0,668 & 0,0286 & 165,6 & 3,17 & 0,126 & 4,13 & 0,227 & 822,6 \\
\hline 100 & $\mathrm{~g} / \mathrm{km}$ & 2,07 & 0,433 & 0,724 & 0,0316 & 178,4 & 3,96 & 0,131 & 5,06 & 0,256 & 990,4 \\
\hline 110 & $\mathrm{~g} / \mathrm{km}$ & 2,72 & 0,442 & 0,782 & 0,0345 & 194,3 & & & & & \\
\hline
\end{tabular}

Iš 2 lentelès pateiktų duomenų matome jog M1 ir N1 kategorijos transporto priemonès, $2011 \mathrm{~m}$. sausio $1 \mathrm{~d}$. duomenimis, sudaro $95,11 \%$ registruotu automobiliu, todèl matematiniam modeliavimui naudojami lengvuju automobiliu vidaus degimo variklių emisijos išmatuotos prie skirtingų automobilių judejjimo greičių (1 Lentelè). Variklių emisijos prie $0 \mathrm{~km} / \mathrm{h}$ perskaičiuotos iš emisijų kai greitis lygus $5 \mathrm{~km} / \mathrm{h}$ su prielaida, kad emisijos bus panašios.

Naudojant matematinius metodus sukuriamos VDV emisijas aprašančios funkcijos, kurios priklauso nuo vieno kintamo parametro - greičio. Funkcijos sudarytos naudojantis programiniu paketu Matlab. Kiekvienos funkcijos sudarymo metodas yra skirtingas, kadangi aproksimuojant buvo ieškomas labiausiai išmatuotus parametrus atitinkanti kreivè

VDV emisijas aprašančios funkcijos, koeficientu reikšmès, sudarytos funkcijos ir išmatuotų reikšmių grafinès išraiškos pateiktos 4.9-4.13 paeiksluose. Regresijos funkcijų atitikimas išmatuotiems duomenims yra 98-99\% visoms pateiktoms funkcijoms.

Šios funkcijos įtraukiamos i matematinị kelių transporto srautų modelị ir naudojamos prognozuojant ir tiriant kelių užterštumo dinamiką. Tokio matematinio modeliavimo pavyzdžiai pateikiami toliau skyriuje. Uždavinys sprendžiamas pasitelkus sukurtą sutelktujų parametrų matematini modeli, kurị sudarančios prielaidos pateiktos 2.1.1 poskyryje, o lygtys aprašytos 2.3 skyriuje. 
2 lentelè. Lietuvoje įregistruotų kelių transporto priemonių skaičiai $(2011 \mathrm{~m}$. sausio $1 \mathrm{~d}$. duomenys)

Table 2. The number of road vehicles registered in Lithuania (data of 1 January 2011)

\begin{tabular}{|c|c|c|c|c|c|c|}
\hline 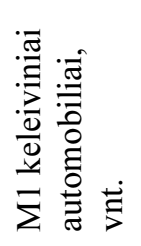 & 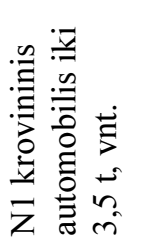 & 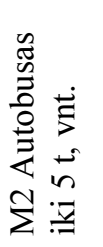 & 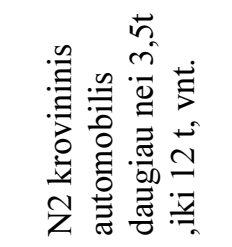 & 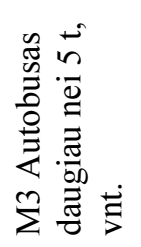 & 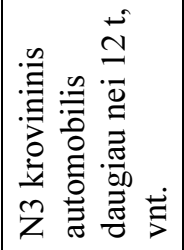 & $\begin{array}{l}\dot{\Xi} \\
\dot{\delta} \\
\dot{0}\end{array}$ \\
\hline 1734047 & 95930 & 7690 & 33628 & 7054 & 45651 & \multirow{2}{*}{1924000} \\
\hline \multicolumn{2}{|c|}{$\mathrm{M} 1+\mathrm{N} 1=1829977$} & \multicolumn{2}{|c|}{$\mathrm{M} 2+\mathrm{N} 2=41318$} & \multicolumn{2}{|c|}{$\mathrm{M} 3+\mathrm{N} 3=52705$} & \\
\hline \multicolumn{2}{|c|}{$95,11 \%$} & \multicolumn{2}{|r|}{$2,15 \%$} & \multicolumn{2}{|r|}{$2,74 \%$} & $100 \%$ \\
\hline
\end{tabular}

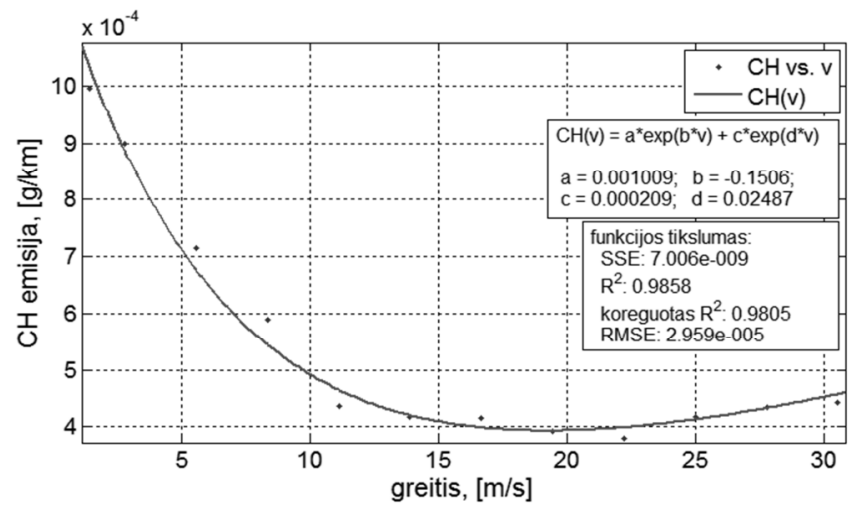

4.9 pav. Vidaus degimo variklio $\mathrm{CH}$ emisijos priklausomybe nuo greičio Fig. 4.9. Dependence of internal combustion engine $\mathrm{CH}$ emission on speed

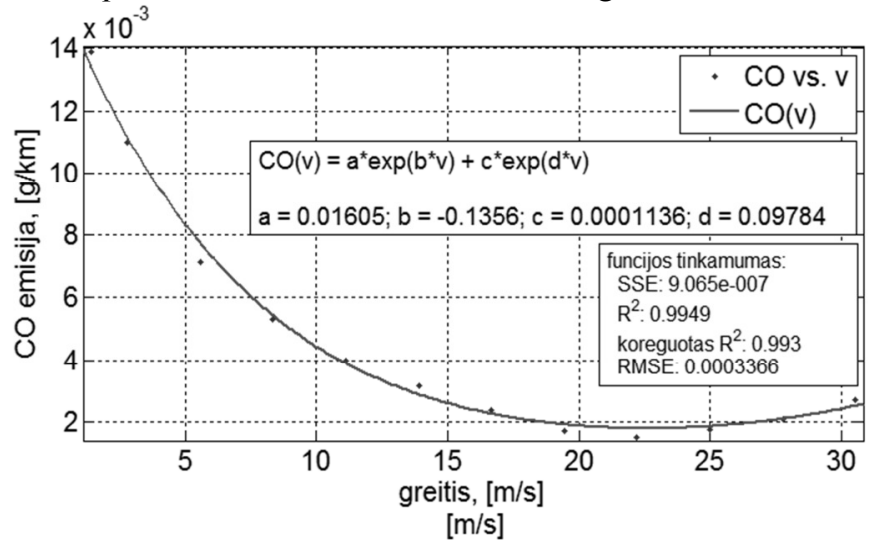

4.10 pav. Vidaus degimo variklio $\mathrm{CO}$ emisijos priklausomybẻ nuo greičio Fig. 4.10. Dependence of internal combustion engine $\mathrm{CO}$ emission on speed 


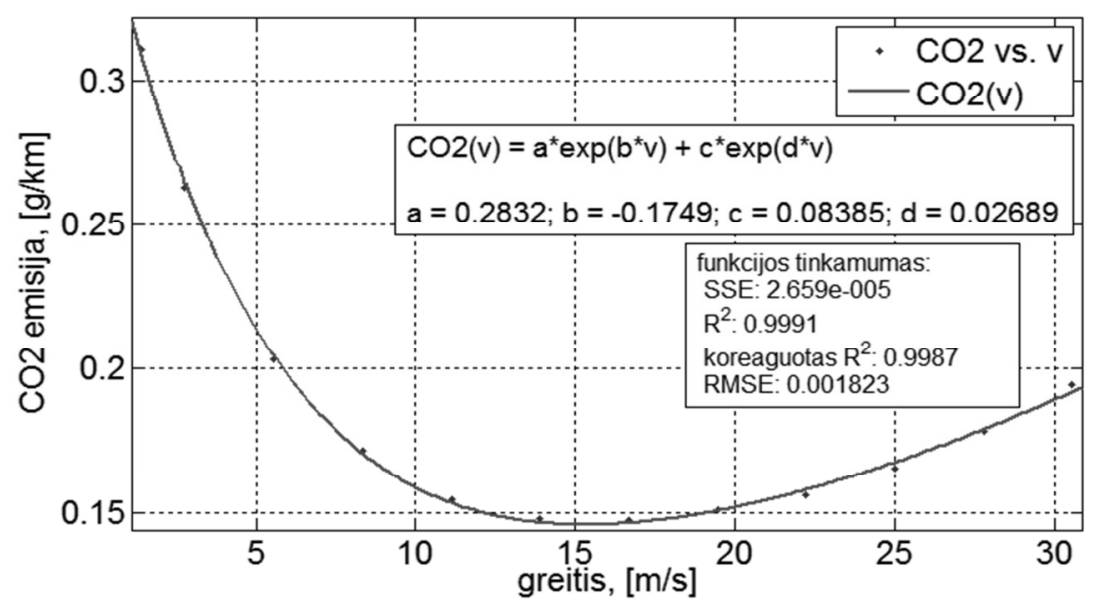

4.11 pav. Vidaus degimo variklio $\mathrm{CO}_{2}$ emisijos priklausomybé nuo greičio Fig. 4.11. Dependence of internal combustion engine $\mathrm{CO}_{2}$ emission on speed

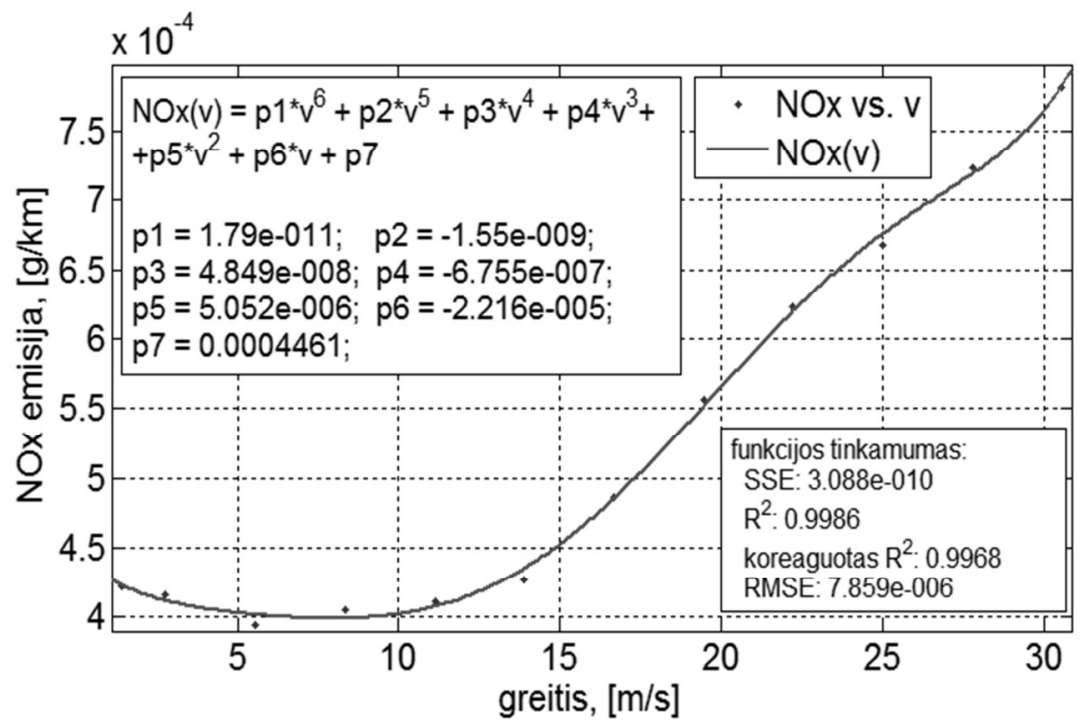

4.12 pav. Vidaus degimo variklio NOx emisijos priklausomybė nuo greičio

Fig. 4.12. Dependence of internal combustion engine NOx emission on speed

Matematinis modelis sudarytas pasinaudojant prielaidomis pateiktomis 2 skyriuje. Modeliavimui imama tiesi, $100 \mathrm{~m}$ ilgio kelio atkarpa, kurios galiniuose taškuose įvedamos kraštinès uždavinio sąlygos. Modeliuojamo kelio ruožas yra sudalintas į 6 atkarpas. Mazguose 1 ir 7 yra ịvestos uždavinio kraštinès sąlygos.

Sprendžiami du uždaviniai. Pagal pirmo uždavinio sąlygas kelias yra pilnai 
užpildytas modeliavimo pradžioje, o kraštinès sąlygos yra šios: $v_{1}=5,0 \mathrm{~m} / \mathrm{s}$; $v_{7}=0,1 \mathrm{~m} / \mathrm{s} ; k_{1}=0,18$ auto $/ \mathrm{m} ; k_{7}=0,18$ auto $/ \mathrm{m}$. Pradiniu momentu visuose mazguose $k=0,01$ auto $/ \mathrm{m}$, o $v=1,0 \mathrm{~m} / \mathrm{s}$. Modeliavimo rezultatai pateikti 4.12-4.17 paveiksluose.

Pagal antro uždavinio sąlygas kelias modeliavimo pradžioje yra tuščias, o kraštinès sąlygos yra šios: $v_{1}=1,0 \mathrm{~m} / \mathrm{s} ; \quad v_{7}=5,0 \mathrm{~m} / \mathrm{s} ; \quad k_{1}=0,01$ auto $/ \mathrm{m}$; $k_{7}=0,01$ auto $/ \mathrm{m}$. Pradiniu momentu visuose mazguose $k=0,18$ auto $/ \mathrm{m}, o$ $v=1,0 \mathrm{~m} / \mathrm{s}$. Modeliavimo rezultatai pateikti D priede.

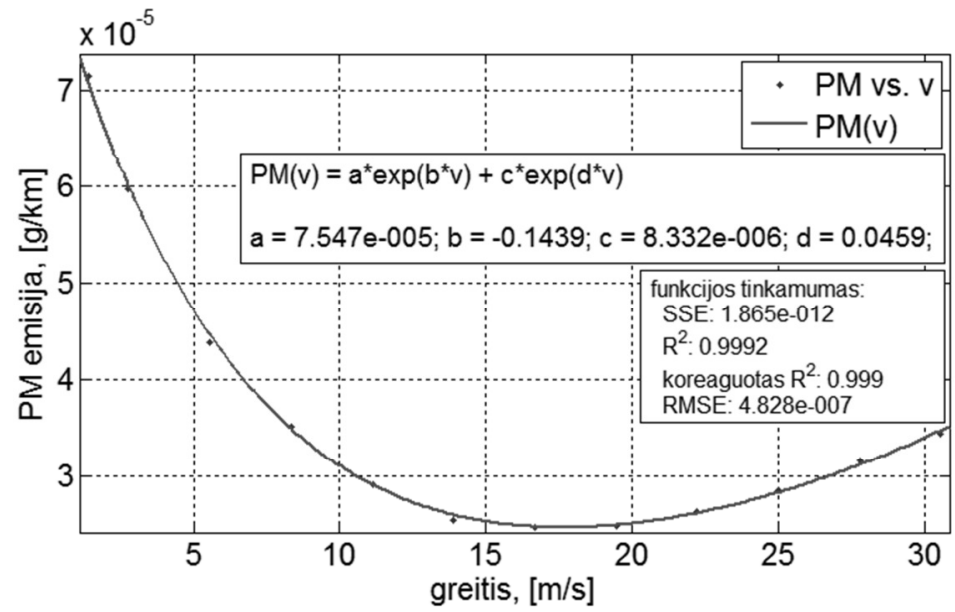

4.13 pav. Vidaus degimo variklio Pm emisijos priklausomybè nuo greičio Fig. 4.13. Dependence of internal combustion engine PM emission on speed

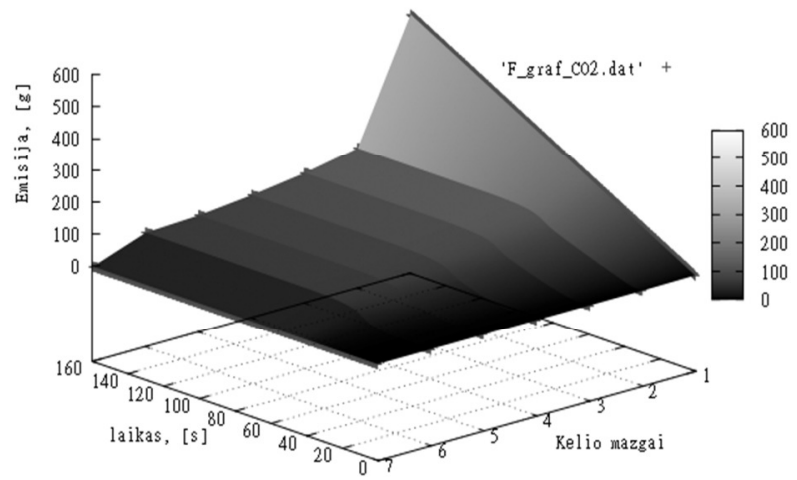

4.14 pav. VDV $\mathrm{CO}_{2}$ emisijos kelio mazguose priklausomybè nuo laiko Fig. 4.14. Dependence of IC engine $\mathrm{CO}_{2}$ emission on time at road points 


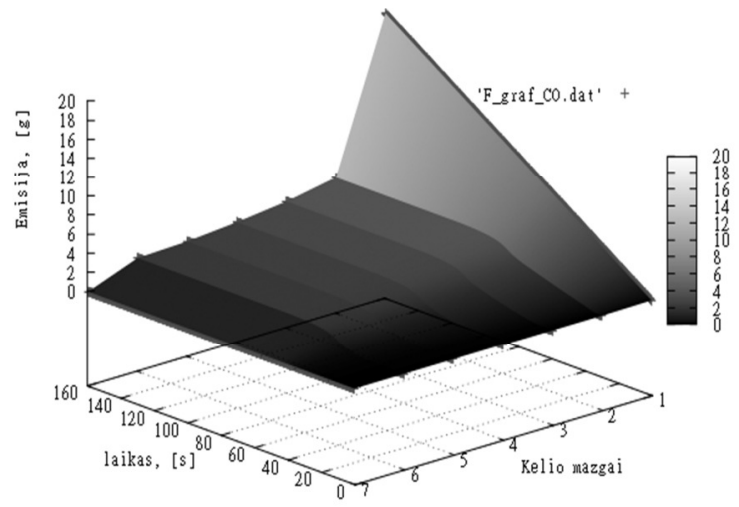

4.15 pav. VDV CO emisijos kelio mazguose priklausomybė nuo laiko Fig. 4.15. Dependence of IC engine $\mathrm{CO}$ emission on time at road points

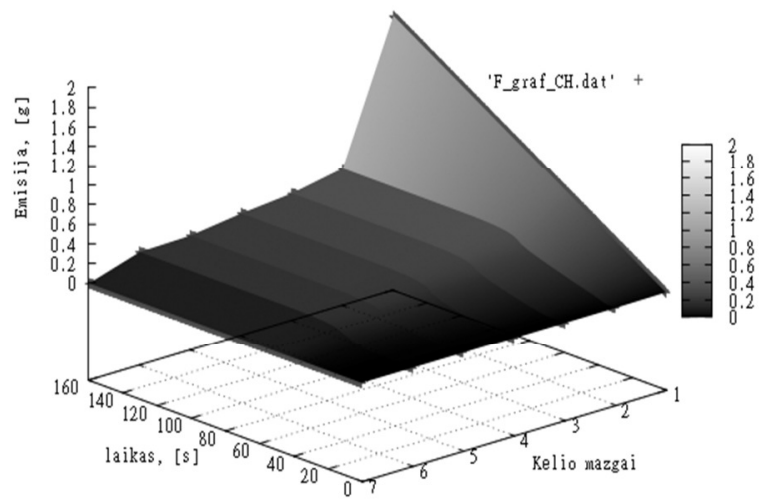

4.16 pav. VDV CH emisijos kelio mazguose priklausomybė nuo laiko Fig.4.16. Dependence of IC engine $\mathrm{CH}$ emission on time at road points

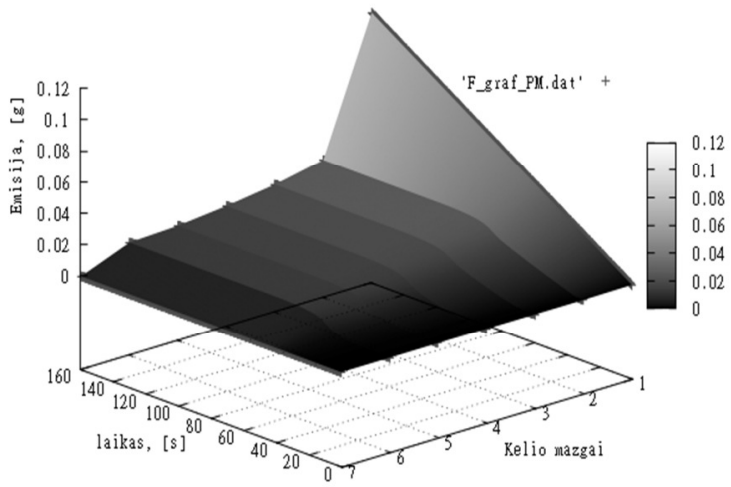

4.17 pav. VDV Pm emisijos kelio mazguose priklausomybè nuo laiko Fig. 4.17. Dependence of IC engine PM emission on time at road points 


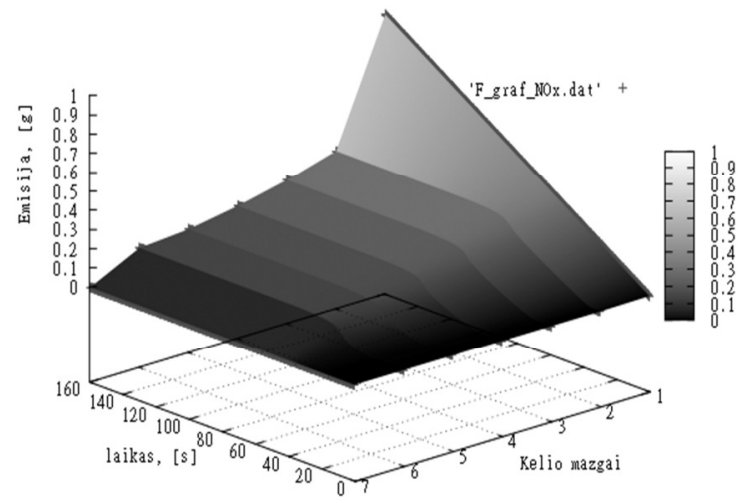

4.18 pav. VDV NOx emisijos kelio mazguose priklausomybè nuo laiko Fig. 4.18. Dependence of IC engine NOx emission on time at road points

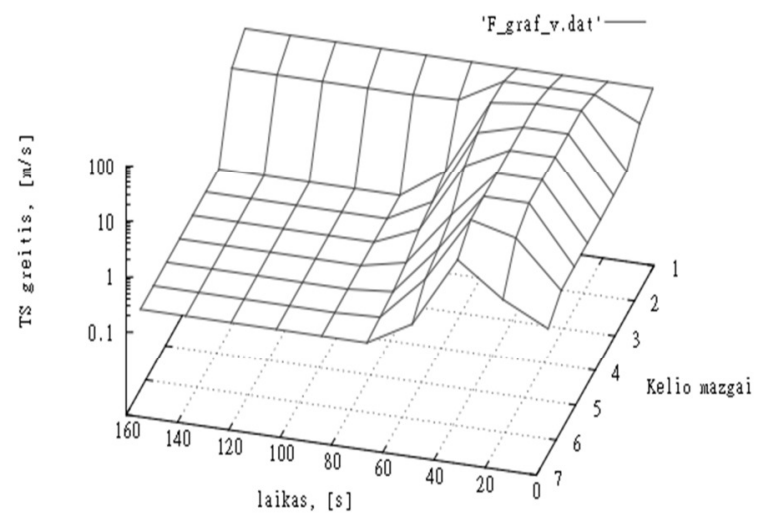

4.19 pav. Automobilių srauto greičio kelio mazguose priklausomybè nuo laiko Fig. 4.19. Dependence of vehicles' flow speed on time at road points

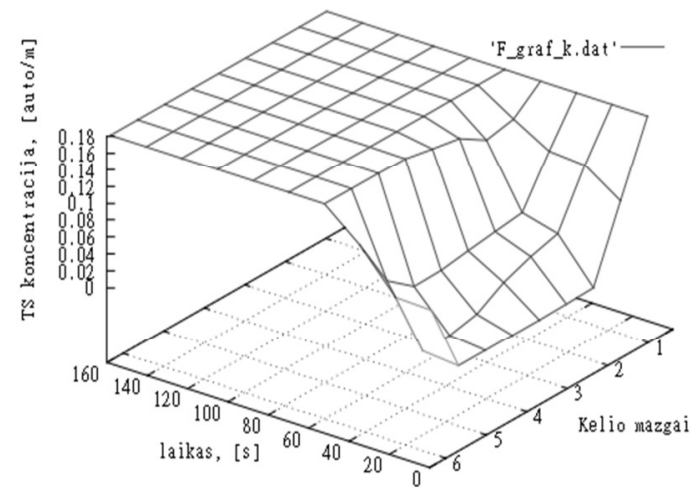

4.20 pav. Automobilių srauto koncentracijos kelio mazguose priklausomybè nuo laiko Fig. 4.20. Dependence of vehicles' flow concentrations on time at road points 
Siekiant išvengti modeliavimo netikslumu yra ịvesti tokie apribojimai. Greičio reikšmès kinta nuo $0,1 \mathrm{~m} / \mathrm{s}$ iki $v_{\max }$. Kai greičio reikšmé lygi $0,1 \mathrm{~m} / \mathrm{s}$ variklio emisijos skaičiuojamos ne pagal gautas išraiškas, o tiesiškai priklauso nuo laiko 4.14-4.20 paveislai. Skaičiuojama pagal lentelès 2 duomenis, kai greitis lygus 0 ir emisijos matuojamos g/h. Emisijos reikšmès perskaičiuojamos i $\mathrm{g} / \mathrm{s}$ ir kiekvienam laiko žingsnyje skaičiuojamos pagal formulę:

$$
E^{t+\Delta t}=E^{t}+\Delta t \cdot E .
$$

Modeliuojami du skirtingi atvejai. Pirmu atveju kelio atkarpa yra tuščia ir modeliuojant yra užpildoma automobiliais, antru atveju modeliavimo pradžioje kelio atkarpa yra pilnai užpildyta ir modeliuojant tušteja. Transporto srauto parametru $\mathrm{k}$ ir v kitimas visuose kelio mazguose detaliai matomas 4.19-4.20 pav. ir D priede. Pirmu atveju kai kelias tuščias greitis kelio mazguose auga iki didžiausio leistino, o keliui užsipildžius sumažèja iki $0 \mathrm{~m} / \mathrm{s} 4.19-4.20$ pav. Antru atveju koncentracija kelio mazguose palaipsniui pradeda mažèti, o greitis palaipsniui, nuo paskutinio kelio mazgo, auga iki didžiausio leistino, D priedas. Šis dèsningumas rodo, kad kelio atkarpa tušteja.

Modeliuojami du skirtingi atvejai. Pirmu atveju kelio atkarpa yra tuščia ir modeliuojant yra užpildoma automobiliais, antru atveju modeliavimo pradžioje kelio atkarpa yra pilnai užpildyta ir modeliuojant tušteja. Transporto srauto parametru $\mathrm{k}$ ir $\mathrm{v}$ kitimas visuose kelio mazguose detaliai matomas 4.19-4.20 pav. ir D priede. Pirmu atveju kai kelias tuščias greitis kelio mazguose auga iki didžiausio leistino, o keliui užsipildžius sumažèja iki 0 m/s 4.19-4.20 pav. Antru atveju koncentracija kelio mazguose palaipsniui pradeda mažèti, o greitis auga iki didžiausio leistino palaipsniui nuo paskutinio kelio mazgo D priedas.

VDV emisijos visuose kelio mazguose auga, kadangi kelio atkarpoje yra automobilių. Pirmu atveju, kai modeliavimo pradžioje kelio atkarpoje automobilių kiekis buvo artimas 0 , VDV emisijos auga visą modeliavimo laiką. Modeliavimo pradžioje šis augimas yra netiesinis, o užsipildžius kelio atkarpai auga tiesiškai, kadangi modeliavimo rezultatams greitis nebedaro įtakos.

Antruoju atveju, kai kelio atkarpa modeliavimo pradžioje buvo pilnai užpildyta, VDV emisijos taip pat auga. Galiniuose kelio mazguose, iš kurių pirmų išvažiuoja automobiliai, emisijos pradeda mažėti. Tai paaiškinama tuo jog kelio gale sumažeja automobilių kiekis ir padideja automobilių greitis.

\subsection{Ketvirto skyriaus išvados}

1. Transporto srautu modeliavimo rezultatai, gauti panaudojant sukurtą transporto srautų tyrimo metodą, sutampa kraštiniuose mazguose. Neatitikimas tarp išmatuotų ir sumodeliuotų rezultatų pastebimas tik 
ties $30000 \mathrm{~s}$ riba. Likusiuose taškuose ịvesta funkcija atkartojama apie $8 \%$ tikslumu. Didesnè paklaida gaunama transporto srauto greičiui - greitis visuose mazguose arteja prie pasirinkto didžiausio galimo greičio.Todèl galima teigti, kad modelis yra tikslus, bet ji būtų galima patikslinti detaliau tikslinant modelio parametrus (funkcijas priklausančias nuo transporto srauto greičio ir koncentracijos).

2. Pasiūlyta koncepcija vidaus degimo varilio emisijoms nustatyti. Ši koncepcija leidžia įvertinti srauto dinaminių charakteristikų ir automobilio kiekio tam tikrame gatvių tinkle įtaką deginių susidarymui. 



\section{Bendrosios išvados}

1. Sukurtas transporto srautų tyrimo metodas leidžia nagrinèti transporto srautą, kaip netiesinę dinaminę sistemą ir ịvertinti staigiai pasikeitusias važiavimo sąlygas bei gatvių tinklo parametrus.

2. Sukurti matematinio modelio elementai miesto gatvių tinklui tyrinèti. Atlikus modelių palyginimą nustatyta, kad sukurto sutelktujų parametru matematinio modelio skaičiavimo pereinamasis laiko tarpas didesnis lyginant su tradiciniu kontinuumo matematinio modelio nusistovejjimo greičiu. Tradiciniam kontinuumo modelyje nusistovejjimo laikas kinta nuo 20 iki $800 \mathrm{~s}$, o tuo tarpu koncentruotu parametrų modelyje nuo 5 iki $60 \mathrm{~s}$, t. y. 4-13 kartų greičiau.

3. Lyginant tradicinio dujų kinetinio matematinio modelio, sutelktujų parametrų matematinio modelio skaičiavimo rezultatus ir eksperimento duomenis pastebimos analogiškos transporto srauto greičio ir transporto srauto koncentracijos kitimo tendencijos. Transporto srauto koncentracijos vertei artejant prie didžiausios leistinos reikšmés transporto srauto greitis mažeja ir artejja prie mažiausios leistinos reikšmès ir atvirkščiai koncentracijos reikšmei artejjant prie mažiausios leistinos reikfmès greičio verte artèja prie didžiausios leistinos 
reikšmès. Didžiausia koncentracijos reikšmè priklauso nuo gatvių tinklo parametrų.

4. Lyginant dujų kinetinio matematinio modelio ir siūlomo matematinio modelio rezultatus pastebima, kad kinetinis matematinis modelis stabiliau dirba kai srauto parametrų verte yra nutolusi nuo kraštinių galimų reikšmių apie $20 \%$. Sprendžiant dujų kinetinio modelio lygtis charakteristikų metodu turi būti išlaikoma Kuranto sąlyga.

5. Iš natūrinių eksperimentų gauta koncentracijos regresijos funkcija nesutampa su teorinio tyrimorezultatais apie $8 \%$. Didesnè paklaida gaunama transporto srauto greičiui - greitis visuose mazguose artejja prie pasirinkto didžiausio galimo greičio. Galima teigti, kad modelis yra tikslus, bet ji būtina patikslinti detaliau tikslinant modelio parametrus (funkcijas priklausančias nuo transporto srauto greičio ir koncentracijos).

6. Pasiūlyta koncepcija vidaus degimo varilio emisijoms nustatyti. Ši koncepcija leidžia ịvertinti srauto dinaminių charakteristikų ir automobilio kiekio tam tikrame gatvių tinkle įtaką deginių kiekio susidarymui.

\section{Tolimesnių tyrimų kryptys}

Ateityje, plètojant metodą, reikètu patikslinti modelio parametrų (funkcijų priklausančių nuo transporto srauto greičio ir koncentracijos) reikšmes ịvertinant atmosferinių veiksnių, vairuotojų ir pėsčiųų elgesio, kelio dangos būklès įtaką transporto srauto intensyvumui. Taip pat reikètų patikslinti kraštinių sąlygų naudojimą aprašant sankryžas.

Išplètojus matematinį metodą, papildomai galima modeliuoti užterštumo miesto gatvių tinkle dinamikos kitimą, susieti matematini modeli su GIS sistemomis ir realiame laike stebèti galimus transporto srautu pasiskirstymus miesto gatvių žemèlapyje. Taip pat plètojant metodą galima kurti navigacines sistemas optimaliai maršruto paieškai atlikti, kai žinomi miesto gatvių tinklo apkrovimai realiame laike.

Sukurtas matematinis transporto srautų modelis gali būti naudojamas tiriant praktinio pobūdžio problemas gatvių tinkle. 


\section{Literatūra ir šaltiniai}

Akgungor. A.P. 2008. A New Delay Parameter on Variable Analysis Periods at Signalized Intersections. Part 2: Validation and Application, Transport 23(2): 91-94.

Al-Deek, H.; Emam, B.E. 2006. New Methodology for Estimating Reliability in Transportation Networks with Degraded Link Capacities, Journal of Intelligent Transportation Systems 10(3):117-129. doi:10.1080/15472450600793586

Al-nasur, S.; Kachroo, P. 2006. A Microscopic-to-Macroscopic Crowd Dynamic model, Proceedings of the IEEE Intelligent Transportation Systems Conference 2006. Toronto, Canada, September 17-20: 606-611.

Angshuman, G. 2004. An Incident Detection Algorithm Based on Discrete State Propagation Model of Traffic Flow: 217 p.

Azzopardi, M.A.; Grech, I.; Leconte, J. 2010. A High Speed Tri-Vision System for Automotive Applications, European Transport Research Review 2(1): 31-51. doi:10.1007/s12544-010-0025-2

Baykal-Gursoy, M.; Xiao, W.; Ozbay, K. 2008. Modelling Traffic Flow Interrupted by Incidents, European Journal of Operational Research: 1-12.

Bazaras, J. 2008. Eismo srautų ir jų sukeliamo triukšmo tyrimai, Daktaro disertacija. $97 \mathrm{p}$.

Bellucci, P.; Cipriani E. 2010. Data Accuracy on Automatic Traffic Counting: the SMART Project Rezults, European Transport Research Review 2(4): 175-187. doi: 10.1007/s12544-010-0039-9 
Bogdevičius, M.; Prentkovskis, O. 2003. Hidraulinių ir pneumatinių sistemų dinamika, Vilnius, Technika. 264 p.

Bonzani, I. 2007. Hyperbolicity Analysis of Class of Dynamical Systems Modelling Traffic Flow, Applied Mathematics Letters 20: 933-937.

Burger, R.; Garcia, A.; Karlsen, K.H.; Towers J.D. 2007. A family of Numerical Schemes for Kinematic Flows with Discontinuous Flux, Journal of Engineering Mathematics 60(3-4): 387-425. doi:10.1007/s10665-007-9148-4

Chalons, C.; Goatin P. 2008. Godunov scheme and sampling technique for computing phase transitions in traffic flow modeling, Interfaces and Free boundaries 10: 197-221.

Chowdhury, D.; Santen , L.; Schadschneider, A. 2000. Statistical Physics of Vehicular Traffic and Some Related Systems, Physics Reports 329(4): 199-329.

doi:10.1016/S0370-1573(99)00117-9

Chronopoulos, A.T.; Johnston, C.M. 1998. A Real-Time Traffic simulation System, IEEE Transaction on Vehicular Technology 47(1): 321-331.

Colombo R.M.; Corli A.; Rosini M.D. 2007. Non local Balance Laws in Traffic Models and Crystal Growth, ZAMM Z.Angew. Math. Mech. 87(6): 449-461. doi:10.1002/zamm.200710327

Dao, Z.Y.; Li, K.P.; Li, X.G.; Huang H.J. Mao B.H. 2007. Scaling laws of the network traffic flow, Physica A 380: 577-584. doi:10.1016/j.phusa.2007.02.036

Descombes, G.; Maroteaux F.; Feidt, M. 2003. Study of the Interaction between Mechanical Energy and Heat Exchangee Applied to IC Engines, Applied Thermal Engineering 23: 2061-2078. doi:10.1016/S1359-4311(03)00160-1

Garavello, M.; Piccoli, B. 2006. Traffic Flow on a Road Network Using the Aw-Rrascle Model, Cominications in Partial Differential Equations 31: 243-275. doi: $10.1080 / 03605300500358053$

Gasser I. 2003 On Non - Entropy Solutions of Scalar Conservation Laws for Traffic Flow ZAMM Z. Angew. Math. Mech. 83(2): 137-143. doi:10.1002/zamm.200310013

Gowri, A.; Sivanandan, R. 2008. Evaluation of Left Turn Channelization at a Signalized Intersection Under Heterogeneous Traffic Conditions, Transport 23(3): 221-229.

Guan, W. 2004 A Qualitative Models of Cross-Line Inhomogeneities in Traffic Flow, IEEE Transactions on Intelligent Transportation systems 5(3): 188-199.

Helbing, D.; Greiner, A. 1998. Modelling and Simulation of Multi-Lane Traffic Flow. $131 \mathrm{p}$.

Herty, M.; Kichner, C.; Klar, A. 2007. Instantaneous control for traffic flow, Mathematical methods in applied sciences 30: 153-169. doi:10.1002/mma.779

Herty, M.; Klar, A.; Pareschiy, L. 2005. General Kinetic Models for Vehicular Traffic Flow and Monte Carlo Methods, Comput. Methods Appl. Math., 5: 155-169.

Ho, F.S.; Ioannou, P. 1996. Traffic Flow Modeling and Control Using Artificial Neural 
Networks, IEEE Control Systems 96(5): 16-26.

Horn, M.E.T. 2006. On-Line Vehicle Routing and Scheduling With Time - Varying Travel Speeds, Journal of Intelligent Transportation Systems 10(1): 33-40. doi:10.1080/15472450500455237

Ilgakojytė J. 2002. Eismo srautų pralaidumo tyrimai vertinant ekologinius veiksnius, daktaro disertacija, $106 \mathrm{p}$.

Ilgakojytė-Bazarienè, J.; Marškaitis, D. 2005. Application of Equilibrium Traffic Flow Model, In Proceedings of 9th International Conference. Transport Means: 59-61.

Illner, R.; Stoica, C.; Klar, A.; Wegener, R. 2002. Kinetic Equilibria in Traffic Flow Models, Transport Theory and Statistical Physics 31(7): 615-634. doi:10.1081/TT-120015626

Yu, L.; Lib, T.; Shi, Z., 2010, The effect of diffusion in a new viscous continuum traffic model, Physics Letters A , 2346-2355.

Jakimavičius, M.; Burinskienè M. 2009. A Gis and Multi-Criteria-Based Analysis and Ranking of Transportation Zones of Vilnius City, Technological and Economic Development of Economy 15(1): 39-48.

Jakimavičius, M.; Burinskienė M. 2010. Route Planning Methodology of an Advanced Traveler Information System in Vilnius City, Transport 25(2): 171-177.

Janulevičius, A.; Juostas A.; Pupinis G. 2010. Engine Working Modes During Tractors Operational Period, Mechanika 3(83): 58-63.

Jiang, J.; Han, G.; Chien, J. 2002. Modelling Turning Restrictions in Traffic Networkfor Vehicle Navigation System, In Proceedings of the International Symposium on Geospatial Theory, Processing and Applications Commission IV, Ottawa.

Jovic, J.; Doric, V. 2010. Traffic and Environmental Street Network Modelling: Belgrade Case Study, Transport 25(2): 155-162.

Kerner, S.B.; Klenov, S.L. 2006. Deterministic Microscopic Three-Phase Traffic Flow Models, Journal of Physics A: Mathematical and General 39: 1775-1809. doi: 10.1088/0305-4470/39/8/002

Khalesian, M.; Phlavani, P.; Delavar, R.M. 2009. A GIS-Based Traffic Control Strategy Planning at Urban Intersections, International Journal of Computer Science and Network Security 9(1): 166-174.

Kim, Y.; Keller, H. 2002. On-Line Traffic Flow Model Applying the Dynamic Flow Density Relation, Road Transport Information and Control, 19-21 March Conference publication 486: 141-145.

Kliukas, R.; Jaras, A.; Kačianauskas, R. 2008. Investigation of the Traffic-induced Vibration in Vilnius Arch-Cathedral Belfry, Transport 23(4): 323-329.

Knowles, J.K. 2008. On Entropy Conditions and Traffic Flow Models, Journal of Applied Mathematics and Mechanics 88(1): 64-73. doi:10.1002/zamm.200700093 
Li, K.; Ioannou, P. 2004. Modeling of Traffic Flow of Automated Vehicles, IEEE Transactions On Intelligent Transportation Systems 5(2): 99-113.

Li, L.; Xu, L. 2008. Linear Stability Analysis of a Multi-Vehicle Car-Following Traffic flow Model, In International Conference on Management Science \& Engineering, 16421647.

Li, X.; Li, Z.; Han, X.; Dai, S.Q., 2009, Effect of the optimal velocity function on traffic phase transitions in lattice hydrodynamic models, Commun Nonlinear Sci Numer Simulat, 2171-2177.

Liu, T.; Jis, L.; Zhu, W. 2008. A New Traffic Flow Model With the Effects of Backward Looking and Relative Current, In Fifth international Conference on Fuzzy Systems and Knowledge Discovery: 438-442.

Yu, L.; Li, T.; Shi, Z. 2009. The effect of diffusion in a new viscous continuum traffic model, Physics Letters A 374 (2010) 2346-2355.

Maccartney, M. 2004. Keep Your Distance! Using Second-Order Ordinary Differential Equations to Model Traffic Flow. International Journal of Mathematical Education in Science and Technology: 588-596. doi:10.1080/00207390410001686634

Makaras, R.; Sapragonas, J.; Keršys A.; Pukalskas S. 2011. Dynamic Model of a vehicle moving in the Urban Area, Transport 26(1): 35-42.

Mansha, M.; Saleemi, A.R.; Ghauri, B.M. 2010. Kinetic Models of Natural Gas Combustion in an Internal Combustion Engine, Journal of Natural Gas Chemistry 19: 6-14. doi:10.1016/S1003-9953(09)60024-4

Markovits-Somogyi, R.; Torok, A. 2010. Statistical Analysis of the Hungarian Vehicle Fleet With Special Emphasis on Emissions, In 11th IAEE European Conference, August 25-28, Vilnius, 2010.

McCrea,J.; Moutari, S. 2010. A hybrid macroscopic-based model for traffic flow in road networks, European Journal of Operational Research, European Journal of Operational Research 207: 676-684.

Mikalauskas, J. 2010. Traffic Control System Simulation, Proceedings of 14th International Conference. Transport Means 2010: 1-4.

Ngoduy, D.; Hoogendoorn, S.P.; Liu, R., 2009, Continuum modeling of cooperative traffic flow dynamics, Physica A 388: 2705-2716.

Ni, D.; Leonard II, J.D.; Williams, B.M. 2006. The Network Kinematic Waves Model: A Simplified Approach to Network Traffic. Journal of Intelligent Transportation Systems 10(1): 1-14. doi:10.1080/15472450500455070

Nikolov, E. 2008. Traffic Flow Model Based on the Green-Function, In 4-th International IEEE Conference "Inteligent systems": 4-26-4-32.

Paliulis, G. M. 2007. Eismo inžinerija : 120 p.

Prigogine I.; Herman, R. 1971. Kinetic Theory of Vehicular Traffic, New York, 1971, $101 \mathrm{p}$. 
Pyragas K. 2003. Netiesinès dinamikos pagrindai, Vilnius, Technika. 304 p.

Quddus, M. A.; Norland, R.B.; Ochieng, W.Y. 2006. A High Accuracy Fuzzy Logic Based Map Matching Algorithm for Road Transport, Journal of Intelligent Transportation Systems 10(3): 103-115. doi:10.1080/15472450600793560

Ragauskaitè, A.; Bagdonas, V.; Sladkowski, A. 2009. Analysis of Uncontrolled Crossing Passage Time, In Proceedings of 13th International Conference. Transport Means: 39-42.

Safonov, L. A.; Tomer, E.; Strygin, V.V.; Havlin, S. 2000. Periodic Solution of a NonLinear Traffic Model, Physica A 285: 147-155.

Shladover S. E.; Tan S.K. 2006. Analysis of Vehicle Positioning Accuracy Rquirements for Communication-Based Cooperative Collision Warning, Journal of Intelligent Transportation Systems 10(3): 131-140. doi:10.1080/15472450600793610

Shukla, A. K.; Jain, S.S.; Parida, M.; Srivastava J.B. 2009. Performance of FHWA Model For Predicting Traffic Noice: A Case Study of Metropolitan City, Lucknow (India), Transport 24(4): 234-240.

Shvetsov V. I. 2003. Mathematical Modeling of traffic flows, Automation and Remote Control 64 (11): 1651-1689.

Siebel, F.; Mauser W. 2006. On The Fundamental Diagram of Traffic Flow, SIAM Journal on Applied Mathematics 66(4): 1150-1162.

Sivilevičius, H. 2011. Modelling the Interaction of Transport System Elements, Transport 26(1): 20-34. doi:10.3846/16484142.2011.560366

Šliupas, T. 2006. Annual Average Daily Traffic Forecasting Using Different Techniques, Transport 21(1): 38-43.

Smit, R.; Brown A.L.; Chan Y.C. 2008. Do Air Pollution Emissions and Fuel Consumption models For Roadways Include the Effects of Congestion in the Roadway Traffic Flow, Environmental Modelling \& Software 23 (1): 1262-1270.

Tampère C. 2004 Human-Kinetic Multiclass Traffic Flow Theory and Modeling With Application to Advanced Driver Assistance Systems in Congestion, 333 p.

Tanczos, K.; Torok, A. 2007. The Linkage Between Climate Change and Energy Consumption of Hungary in the Road Transportation Sector, Transport 22(2): 134-138.

ÚTMUTATÓ a külterületi közúthálózati fejlesztések költség-haszon vizsgálatához II. külső hatások [Vadovas priemiesčio kelių tinklo plètros išlaidų ir naudos tyrimas.II poveikis aplinkai]. 2006. Gazdasági és Közlekedési Minisztérium Hálózati Infrastruktúra Főosztály [Ekonimikos ir transporto ministerija Tinklų infrastruktūros departamentas]. 23 p. (Vengriškai)

Velasco, R. M.; Saavedra, P. 2008. Macroscopic Models in Traffic flow, Qualitative Theory of Dynamical Systems 7: 237-252. DOI: 10.1007/s12346-008-0014-1

Waldeer; K.T. 2004. A Vehicular Traffic Flow Model Based on a Stochastic Acceleration Process, Transport Theory and Statistical Physics 33(1): 7-30. doi:10.1081/TT-120030341 
Wang, H.; Fu, L.; Zhou, Y.; Li, H. 2008. Modelling of theFuel Consumption for Passenger Cars Regarding Driving Characteristics, Transport Research Part D 13: 479482.

Wie, J.; Fan, B.; Gan, H.; Yang, J. 2008. Raoute Control for Freeway Networks Via Nonlinear Optimization Approach. In Proceedings or the 7th World Congress on Intelligent Control and Automation, 2935-2939.

Wu, J.; Liu J. 2011. Development of a Predictive System For Car Fuel Consumption Using an Artificial Neural Network, Expert Systems with Application 38: 4967-4971.

Xie D .F.; Gao Z. Y.; Zhao, X .M.; Li. K. P. 2009. Characteristics of Mixed Traffic Flow With Non-Motorized Vehicles and Motorized Vehicles at an Unsignalized Intersection, Physica A 338 : 2041-2050.

Zhang, P.; Wong S. C.; Dai, S. Q. 2009, A conserved higher-order anisotropic traffic flow model: Description of equilibrium and non-equilibrium flows. Transportation Research Part B 43: 562-574.

Žiliūtè, L.; Laurinavičius, A.; Vaitkus A. 2010. Investigation Into Traffic Flows on High Intensity Streets of Vilnius City, Transport 25(3): 244-251.

Иносэ, Х.; Хамада, Т. 1983. Управление дорожным движением, 248 с.

Сильянов, В. В. 1977, Теория транспортных потоков в проектировании дорог и организации движения, 304 с. 


\section{Autoriaus publikaciju disertacijos tema sąrašas}

\section{Straipsniai recenzuojamuose mokslo žurnaluose}

Junevičius, R.; Bogdevičius, M.; Torok, A. 2011 Modelling of Internal Combustion Engines'(Ice) Emission Through the Use of Traffic Flow Mathematical Models, Transport (3): 271-278. ISSN 1648-4142 (Thomson ISI Web of Science). doi:10.3846/16484142.2011.621978

Junevičius, R.; Bogdevičius, M. 2009. Mathematical Modelling of Network Traffic Flow, Transport 24(4): 333-338. ISSN 1648-4142. (Thomson ISI Web of Science). doi:10.3846/1648-4142.2009.24.333-338

Junevičius, R.; Bogdevičius, M. 2007. Determination of Traffic Flow Parameters in Different Traffic Flow Interaction Cases, Transport 22(3): 236-239. ISSN 1648-4142. (Thomson ISI Web of Science). doi:10.1080/16484142.2007.9638131

\section{Straipsniai kituose leidiniuose}

Junevičius, R.; Bogdevičius, M.; Hunt, U. 2007. Roundabout Traffic Flow Intersection, Proceedings of $11^{\text {th }}$ International Conference. Transport Means, 10-14. ISSN 1822296X. 
Junevičius, R.; Bogdevičius, M. 2008. Traffic Flow Discreet Model Based on Hutchinson Equation, Technologijos mokslo darbai vakaru Lietuvoje 6: 203-206. ISSN $1822-4652$.

Junevičius, R.; Bogdevičius, M. 2007. Transporto srautu modeliavimo tiesioje kelio atkarpoje kritiniai momentai, iš 10-sios Lietuvos jaunuju mokslininku konferencijos „Mokslas - Lietuvos ateitis “; 40-45. ISBN 978-9955-28-374-4.

Junevičius, R. 2006. Kelių transporto srautų modeliavimo galimybès, iš 9-sios Lietuvos jaunuju mokslininku konferencijos „,Mokslas - Lietuvos ateitis “; 29-35. ISBN 9986-05991-7. 


\section{Summary in English}

\section{Introduction}

\section{Formulation of the Problem}

Different research methods could be taken to research the traffic flows. The best function value selection at existing condisions is the thing that is looking for in the solutions of the mathematical models. Then the task for the control systems is the effectiv traffic flow functioning and the safety.

The established conditions can be described in the following way: the identification (possibility) of the best value of the established function; the completion of vehicle manoeuvres at a given time interval with minimal cost (effectiveness); the completion of the given task using the functioning program with the imposed tight restrictions (reliability); collaboration with an urban traffic control system seeking for the improved procedures in the urban traffic networks (compatibility).

At the moment discrete, continuum and follow the leader traffic flow models are used to model the traffic flows. These models deriving traffic flows in a different way. A lot of models do not involve sudden changes in driving conditions, but are using the discreate values of the traffic flow parameters.

To asses sudden changes inthe driving conditions it is posible to use the continuum traffic flow models. These models are using equations with partial derivatives. They are precise, but the solution of these equations is complex and is taking time.

Assessing sudden changes in driving conditions and forecasting of the traffic flow distribution on the network of the streets, it is possible: to select properly the traffic light 
control algorithms; forecast possible congestion on the network of streets and offer their disposal strategies to predict vibrations, nosies, air pollution trends in the exchange of the street networkload; offer effective street loading stratagies for the implementation of the selected conditions.

\section{Topicality of the Thesis}

A number of papers describing the models of traffic flows outline that, considering concentration value, the flows can be either stable or unstable while traffic speed depends on flow concentration.

The majority of the authors define traffic flows as the stable ones. The parameters of flow concentration, speed and flow intensity are interrelated either forming the so called "fundamental curve" or introducing a mathematical expression to determine the distribution of traffic speed depending on concentration. In order to accurately model traffic flow, a necessity to mathematically describe an unstable traffic flows arises. In that case, the description of traffic flows distinguishes two states of the flow: the stage of a stable traffic flow is described with reference to a gradually sliding curve, whereas that of the unstable traffic flow is defined regarding a few curves.

A mathematical simulation of vehicular traffic flows, including intersections and applying continuum methods, points to inaccuracies in simulation results when traffic at the intersection is stopped and starts moving after a while. Then, equations contain information on disagreements between adjacent nodes (ramen problem) and the results of the conducted mathematical experiment do not reflect the obtained data confirmed by experimentation. Consequently, to avoid system overload, a task in making a decision on incoming and outgoing traffic routing from incoming to outgoing lanes is approached. The type of the intersection and the number of lanes in the intersection make additional difficulties in the mathematical description of intersections. In case the intersection is under control, the mathematical model is relatively simpler, because the direction of traffic flows is established in accordance with regulatory signals. Meanwhile, along with a number of different parameters and conditions, traffic description is more complex in the unregulated intersections as priority-required traffic conditions in the conflict points of the intersection need to be pointed out thus indicating the allowable time intervals to cross the counter flow lane. These parameters start playing a central role when a description of establishing conditions under which a flow can be diverted to another lane or when its trajectory intersects with the trajectory of the other existing lane becomes necessary.

A comparison of the above described models reveals the advantages and disadvantages of specific models. Continuum models are suitable for simulating macroscopic systems of traffic flows; however, mathematical expressions of those are complex and can be hardly solved employing numerical methods. Though mathematical methods for vehicle tracking have a mathematically simpler expression, anyway, difficulties may occur when different types of vehicles having individual parameters need to be described. Nevertheless, in case of dealing with small tasks, similar models are very useful. They can be applied for simulating the interaction between several vehicles, solving safety problems of active traffic etc. The third group embraces statistical methods that use the aggregated parameters of traffic participants. In this case, along 
with the parameters of traffic participants, a sequence of parameters used for simulating traffic flows or flow elements is made. The advantage of the latter methods is complete discreteness while continuum and vehicle tracking models can only apply certain discrete parameters of traffic flow. However, these methods contain disadvantages as they reject maximum and minimum measured values and suggest generalised data on measurements performed within a certain period of time.

The above presented model of distribution points to a fairly precise example of traffic flows. The model that is easily adaptable to fulfilling different transport tasks could be successfully used for solving equations applying numerical methods or several types of models could be combined to deal with a specific problem

\section{The Object of Research}

The research object of the paper focuses on mathematical simulation and investigation into transport flows in the urban area.

\section{The Aim of the Thesis}

The thesis is aimed at creating a universal model for regulating traffic flows in the network of the urban area. The model is a useful tool for solving problems of engineering, environment protection and controlling traffic flows.

\section{The Tasks of the Thesis}

To achieve the aim of the paper, the following tasks must be solved:

- to analyze the available continuum models of traffic flows;

- to suggest the concept for a new mathematical model. The model should be transitional between traditional continuum and discrete models;

- to create a new mathematical model for simulating traffic flows;

- to compare continuum and created traffic flows models;

- to make an experiment and using the results of this experiment to check the created model;

- to give an example of some possible use of the model.

\section{The Research Methods}

The paper applies the methods of probability theory, optimization and digital simulation.

\section{Scientific Novelty}

In the run of preparing the doctoral thesis, the following new scientific findings on the transport engineering have been revealed:

- a mathematical model for simulating traffic flows and their elements has been created;

- an innovative way of dealing with problems caused by transport (an example of how to forecast air pollution caused by internal combustion engines in the street) has been presented; 


\section{Defended Statement}

- Traffic flow on a street network could be investigated as nonlinear dynamic system with a time delay assessing the suddent changes in driving conditions and steet network parameters.

- Forecasting of the air pollution from internal combustion engine emissions can be made on the network of streets assessing the dynamic characteristics of the traffic flow mathematical model with the concentrated parameters.

\section{Practical Significance of the Obtained Results}

The results of findings can be used for simulating traffic flows in the separate elements of lanes, intersections and street network. The model or its elements can be developed and used for applied systems such as finding an optimal route, information on the load of the streets situated in the urban network, the evaluation of the options of redistributing vehicle flows, street reconstruction, arranging new streets etc.

\section{Approval of Research Results}

The subject matter of the above presented thesis was discussed in 7 scientific articles: three articles were published in the Thompson ISI Web of Science journals, one - in the ISI Proceedings, one - in the peer-reviewed material of the international conference and two - in the material of other national and international conferences.

The research results were presented in five scientific conferences:

- International Conference "TRANSBALTICA 2012" 2012. Vilnius;

- International Conference "TRANSBALTICA 2010" 2010. Vilnius;

- 10th International Conference "Transport Means", 2007, Kaunas;

- 10th Conference of Young Scientists of Lithuania "Science - Lithuania“s Future. TRANSPORT" 2007, Vilnius;

- 9th Conference of Young Scientists of Lithuania „Science - Lithuania‘s Future. TRANSPORT" 2006, Vilnius.

\section{The Structure of the Thesis}

The thesis covers introduction, five chapters and conclusion of findings, including three appendixes.

The volume of the thesis is 126 pages, excluding appendixes. The paper also contains 84 numbered formulas, 72 pictures, 2 tables and 85 sources.

\section{Analysis of Scientific Literature.Traffic Flows Mathematical Models}

The first chapter of the thesis reviews the used scientific literature.

The chapter covers four large groups describing mathematical models of traffic flows: discrete, vehicle tracking and continuum models are applied for completing the tasks of applied nature. The review primarily focuses on mathematical continuum hydrodynamic and kinetic models. 
These mathematical models accept vehicle flow as the entire medium. Classical mathematical models are made of vehicle flows applying the kinetic theory of gases based on Boltzmann equations for a gas flow. The kinetic theory of gases used for simulating traffic flows was first introduced by Prigogine, Herman (1971) and was quoted by a number of authors in later published articles. Summing-up the theory formulated by Prigogine, Herman is presented in the text below. When traffic in the streets is rather slow-moving, it can be maintained that a driver of every vehicle does not communicate with the drivers of other vehicles. This way, the true equality is as follows:

$$
\frac{\partial f}{\partial t}+v \frac{\partial f}{\partial x}=0 .
$$

The above equation shows that changes in the quantity of vehicles in elementary area $d x d v$ equal to the difference of vehicles entering and leaving the area. This equality indicates that the function of speed distribution at the moment of time $t$ is equal to the function of speed distribution at point $x-v t$ at the moment of time $t=0$.

Under real conditions, another important aspect is that a vehicle is a participant of a continuous flow. Then, vehicle movement is influenced not only by a driver of a specific vehicle but also by the drivers of other vehicles. In this case, a function of speed distribution $f_{0}(x, v, t)$ is introduced. Parameter $f_{0}(x, v, t) \mathrm{dvdt}$ points to the amount of the vehicles the drivers of which in road interval $\mathrm{dx}$ at time interval $t$ move in the interval of speeds between $v$ and $v+d v$. According to driver distribution in a particular section of the road, two versions of relaxation considering a desired speed distribution function are possible: after a certain time, the drivers either return to or reach the desired distribution function or due to resulting interference on the road, get into the so called "traffic jams". Relaxation law (return to equilibrium position) in the system of traffic flows is expressed using a differential expression:

$$
\frac{\partial f}{\partial t}=-\frac{f-f_{0}}{T}
$$

where $T$ - relaxation time

The authors present the equation of vehicle flows in the form of the following dependence:

$$
\frac{\partial f}{\partial t}+v \frac{\partial f}{\partial x}=-\frac{f-f_{0}}{T} .
$$

The above equation does not evaluate driver interaction and indicates that following a certain amount of time $T$, general flow speed distribution function $f$ will be approximately equal to $f_{0}\left(f \approx f_{0}\right)$. Therefore, in order to evaluate driver interaction, the right side of equation 1.9 is resolved into real and changeable parts

$$
\frac{\partial f}{\partial t}+v \frac{\partial f}{\partial x}=\left(\frac{\partial f}{\partial t}\right)_{r e l}+\left(\frac{\partial f}{\partial t}\right)_{\mathrm{int}} .
$$

The real part of the right part of equation (4) is equal to 


$$
\left(\frac{\partial f}{\partial t}\right)_{\text {rel }}=-\frac{f-f_{0}}{T},
$$

whereas the changeable part of equation (4) is equal to

$$
\left(\frac{\partial f_{i}}{\partial t}\right)_{\mathrm{int}}=\sum_{j}\left(\Gamma_{i j}^{(+)}-\Gamma_{i j}^{(-)}\right)(1-P)=f_{i}(x, v, t) c(x, t)\left[\bar{v}(x, t)-v_{i}\right](1-P) .
$$

The hydrodynamic theory is based on Navje-stocks equations describing fluid flow. The LWR theory is based on two main parameters: the flow concentration of a certain large section of road $k(x, t)$, the amount of vehicles in the length unit and flow $Q(x, t)$ at a given moment of time $t$; the equation describing the flow is the first order differential equation. Flow integrity is defined by the equation

$$
\frac{\partial c(x, t)}{\partial t}+\frac{\partial Q(x, t)}{\partial x}=\sum_{i=1}^{Q_{m}} \alpha_{i}\left(x-x_{i}, t\right)-\sum_{i=1}^{Q_{m}} \beta_{i}\left(x-x_{j}, t\right) .
$$

These expressions are formulated as follows:

$$
\begin{aligned}
& \alpha_{i}\left(x-x_{i}, t\right)=\alpha_{i}^{0}(t) \phi_{i}\left(x-x_{i}\right) ; \\
& \beta_{j}\left(x-x_{j}, t\right)=b_{j}^{0}(t) \phi_{j}\left(x-x_{j}\right),
\end{aligned}
$$

where the right side of the equality (7) describes the value (changes in the value) of the flow input and output of the i-th road section.

where expressions of the equality (8) $\phi_{j}\left(x-x_{j}\right)$ and $\phi_{i}\left(x-x_{i}\right)$ describe flow fluctuations and coefficients $b_{j}^{0}(t)$ and $\alpha_{i}^{0}(t)$ indicate instantaneous flow changes.

Expression (7) cannot be solved as an individual equation as it has two unknown quantities $k(x, t)$ and $Q(x, t)$. This equation can be solved only in the case when unknown quantities are interrelated and one unknown quantity is established referring to other unknown quantity.

\section{The Investigation of the Created Traffic Flows Models}

Section 2.1 of Chapter 2 introduces preconditions for describing traffic flows. The preconditions are used for defining the process of producing traffic flows in the straight road sections and intersections. Section 2.2 presents two traditional mathematical models of traffic flows: a kinetic model is determined applying the method of characteristics, whereas a hydrodynamic model - employing the finite difference method. Section 2.3 suggests a new mathematical model which is the object of this thesis.

A precondition that vehicles cannot enter the oncoming traffic lane is accepted. Therefore, the road is subdivided into separate lanes and two-way roads in the mathematical model are described as separate ones, one-way roads or roads having one 
or more lanes. A lane stretch in the model is taken as the finite length straight divided into the sections of the equal length of $L_{i, i+1}$ (Fig 1S). The parameters of the road section (speed, concentration or intensity of traffic flow) appear at the end points of the sections. A point connecting two adjacent sections has a general point belonging to both sections. The first and the last points of the examined lane are correspondingly the points of transferring data to boundary conditions. The highest and the lowest values of traffic flow parameters for every road section are set on an individual basis and may vary. A minimal value of traffic speed and concentration is usually taken at zero. Minimal traffic speed and concentration values are usually equal zero. The highest possible speed value is established with reference to observations. The highest admissible value of traffic concentration can be calculated according to the formula:

$$
k=\frac{n}{L_{i, i+1}},
$$

where $\mathrm{n}$ - the number of vehicles (items), $L_{i, i+1}$. - the length of the road section (m).

The simulation process accepts the precondition that road sections cannot be overloaded. If the quantity of vehicles in the road section reaches the upper limit, no more vehicles can enter this section. If the road section is full and the value of traffic flow remains the same, increases, slightly decreases or a decrease is insignificant and the front section of the road remains overloaded, the vehicles start concentrating on the following road section that runs immediately after the overloaded road section.

Traffic speed is also limited. Every road section is provided with the maximum allowable speed that may vary in every section.

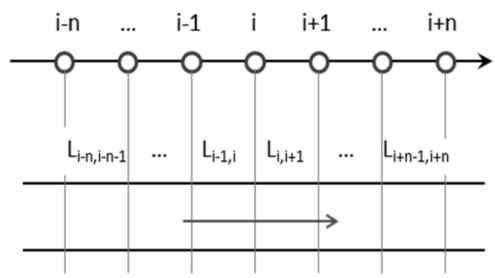

Fig. 1S. Transport flow model on a straight segment of a traffic lane

If the road has a few one way-lanes, simulation accepts the precondition that only one lane having proportionally increased concentration parameters exists. This precondition allows combining a few one-way lanes into the single one to simplify the model as then no evaluation of vehicle migration from one lane to another is needed.

The fragmented sections of the lanes in the model are numbered as $L_{i-1, i}, L_{i+1, i}$, when $i=1 \ldots n,-$ the number of the road point (Fig. 2S). The first point of the element is matched to the last preceding point, whereas the last point is matched to the first following point of the element. Boundary conditions for the task are introduced to marginal elements at the first point of the first element and at the last point of the last element of the road.

The above introduced points of boundary conditions (Fig 2S) are points 1 and 7. 
Throughout the entire simulation time, these points contain all available incoming and outgoing information. In this case, the system most frequently takes the flow value that can remain stable or change according to a certain predictable law during the entire simulation time.

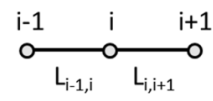

a)

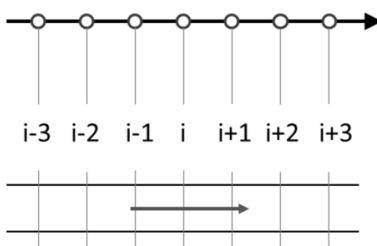

b)

Fig. 2S. Description of elements of a straight road. a) two elements $L_{i-1, i}$ and $L_{i+1, i}$, are connected at point $i$; b) a straight road segment drawn from several road segments connected at points 1-7

When describing the crossings of lanes at intersections to interconnect the elements of the straight lane, boundary conditions must be agreed.

An intersection is taken as a separate element of the traffic system made of a node having one or a few incoming and outgoing lanes. The arrows in the intersection model (Fig 3S) indicate the directions of the incoming and outgoing lanes at the intersection

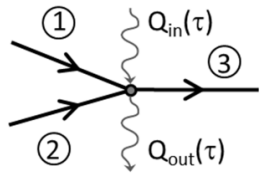

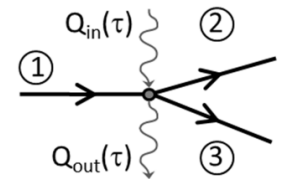

a) b)

Fig. 3S. The intersection schemes of lanes: a) lane merger; b) lane branching

Straight sections 1, 2 and 3 are simulated as described in Part 2.1.1 and the point of lane intersection has the following boundary conditions for scheme a)

$$
\begin{gathered}
p_{1}(k v)_{D, 1}+p_{2}(k v)_{D, 2}-p_{3}(k v)_{D, 3}+p_{4} Q_{0 u t}(t)-p_{5} Q_{i n}(t)=0, \\
\sum_{i=11}^{2} p_{i}=1 . \sum_{i=3}^{5} p_{i}=1 .
\end{gathered}
$$

scheme b)

$$
\begin{gathered}
p_{1}(k v)_{D, 1}-p_{2}(k v)_{D, 2}-p_{3}(k v)_{D, 3}+p_{4} Q_{0 u t}(t)-p_{5} Q_{i n}(t)=0 ; \\
p_{1}=0 \ldots 1, \sum_{i=2}^{5} p_{i}=1 .
\end{gathered}
$$

The parameters of traffic flow $k$ and $v$ used in equations (10) and (12) are calculated in the below presented mathematical expressions, and probabilities $p$ can be established as constants having regular values and functions varying over time and 
subject to the parameters of traffic flow at the first element following the intersection.

The equations of the developed mathematical model for traffic flow considering each point of road $i$ are expressed in the following way:

$$
\begin{aligned}
& \dot{k}_{i}=p_{\text {in }, i}(t) \cdot r_{k_{i}, \text { in }, i} \cdot\left(1-\frac{k_{i}(t)}{k_{\max , i}}\right) \cdot\left(\frac{q_{i-1}\left(t-\tau_{i-1}\right)}{q_{\max , i-1}}\right) \cdot k_{i}(t)- \\
& -p_{\text {out }, i}(t) \cdot r_{k_{i}, \text { out }, i} \cdot\left(1-\frac{k_{i+1}(t)}{k_{\max , i+1}}\right) \cdot\left(\frac{q_{i}(t)}{q_{\max , i}}\right) \cdot k_{i}(t) ; \\
& \dot{v}_{i}=p_{\text {in }, i}(t) \cdot r_{v_{i}, \text { in }, i} \cdot\left(\frac{v_{i-1}\left(t-\tau_{i-1, i}\right)}{L_{i-1, i}}\right) \cdot\left(1-\frac{k_{i}(t)}{k_{\max , i}}\right) \cdot v_{i}(t)+ \\
& +f_{i}\left(k_{i+1, i}\right)-p_{\text {out }, i}(t) \cdot r_{v_{i}, \text { out }} \cdot\left(\frac{1}{2} \frac{v_{i}(t)+v_{i+1}(t)}{L_{i+1, i}}\right) \times \\
& \times\left(1-\frac{k_{i+1}(t)}{k_{\max , i+1}}\right)^{m_{1}} \cdot v_{i}(t)-\left(\frac{v_{i}(t)}{v_{\max , i}}\right) \cdot e^{\left[\gamma_{3}\left(\frac{k_{i}(t)}{k_{\max , i}}\right)^{m_{2}}\right] \cdot\left(\frac{v_{i}(t)}{v_{\max , i}}\right),}
\end{aligned}
$$

where for the sake of simplicity, the parameters applied in equations are interpreted using no indexes $i ; k$ and $v$ - the wanted parameters of traffic flows: traffic flow (TF) concentration and speed; $k_{\max }$ - maximum allowable TF concentration in the road section (auto/m); $v_{\max }$ - maximum allowable TF speed in the element $(\mathrm{m} / \mathrm{s}) ; L_{i-1, i}$ and $L_{i+1, i}$ - the length of a discrete road section $(\mathrm{m}) ; \tau$ - time interval required for traffic flow to follow the road section the length of which equals $L_{i-1, i}$ or $L_{i+1, i}(\mathrm{~s}) ; m_{1}, m_{2}, \gamma-$ constants; $q$ - traffic intensity (auto/s); $q_{\max }$ - the highest possible flow intensity (auto/s); $r_{k, \text { in }}, r_{k, \text { out }}$ the value of the function making corrections to the expression of changes in flow concentration; $r_{v, \text { in }}, r_{v, \text { out }}-$ the values of the function making corrections to the expression of changes in flow speed. Functions $r$ depend on the values of concentration and speed; moreover, these functions can have different values when trafic flow enters the element or leaves it; $p_{\text {in }}(t)$ and $p_{\text {out }}(t)$ - the probability of flow access to the front section. Functions $p_{\text {in }}(t), p_{\text {out }}(t)$ vary over time depending on changes in the values of traffic flow concentration and speed or can be introduced as control functions; $f_{i}\left(k_{i+1, i}\right)$ - a function that depends on the unknown parameter $k$. This function describes the state of the road section element situated in front of node $i$, i. e. points to the degree of intensity regarding this particular section of the lane.

$$
\begin{aligned}
& f_{i}=\left\{\begin{array}{c}
e^{\gamma_{2}\left(1-\frac{\varepsilon_{i+1}}{\varepsilon_{i}}\right) \varepsilon_{i} \cdot \operatorname{sign}\left(p_{\text {out }, i}(t)\right) \operatorname{sign}\left(1-\frac{\varepsilon_{i+1}}{\varepsilon_{i}}\right)}, \text { when } \varepsilon_{i}>\varepsilon_{i+1} \text { ir } \varepsilon_{i}>0, \\
0, \text { in other case }
\end{array}\right. \\
& \varepsilon_{i}=\frac{k_{i}}{k_{\max , i}}
\end{aligned}
$$


The obtained functions of changes in flow parameters over time have the following advantages if compared with equations (14) and (15).

- both functions of the parameters vary in time and make impact on one another;

- specified empirical coefficients $r$ are introduced, and therefore modify sudden jumps in the unknown parameter values;

- the functions allow concentration value to obtain zero value and functions do not approach $\infty$;

- the distance between two adjacent points of the road is evaluated;

- delay is assessed, i.e. the evaluated time interval is necessary for flow participants to get from one point of the road to the one situated next.

The members of equation system (14), (15) make corrections to the searched parameters of flow speed and concentration.

The member $1-\frac{k_{i}(t)}{k_{\max , i}}$ of equation (14) describes the rate of traffic concentration at node $i$. The member of equation $1-\frac{k_{i+1}(t)}{k_{\max , i+1}}$ defines the rate of traffic concentration at node $i+1$. Along with an increase in traffic concentration that occurs in the lane section located in front of node $i$, the value of this member approaches zero (the process of loading the element approaches the highest possible concentration in the section) following the direction of traffic flow. Thus, the introduced restrictions prevent from overloading the element of the lane section. Moreover, when traffic concentration at points $i$ and $i+1$ approaches value $\mathrm{k}_{\max }$, concentration rate decreases.

The member $\frac{q_{i-1}\left(t-\tau_{i-1}\right)}{q_{\max , i-1}}$ of equation (14) describes the state of traffic flow before node $\mathrm{i}$ following the direction of traffic flow. This member describes an increase in flow concentration or a decrease in the i-th node subject to flow intensity in the lane section up to point i. Time interval $\tau_{i-1}$ is also evaluated as this is the time during which the flow travels from one node to another. This delay allows a more precise description of flow movement from one node to another in cases when the distance between the nodes is relatively large and flow speed approaches $0 \mathrm{~m} / \mathrm{s}$ but is not equal to 0 . Delay time increases when the distance between the nodes increases and flow speed in the section decreases.

The member $\left(\frac{v_{i-1}\left(t-\tau_{i-1, i}\right)}{L_{i-1, i}}\right) \cdot v_{i}(t)$ of equation (15) describes traffic acceleration at node $\mathrm{i}+1$, whereas member $\left(\frac{1}{2} \frac{v_{i}(t)+v_{i+1}(t)}{L_{i+1, i}}\right) \cdot v_{i}(t)$ refers to the average traffic acceleration between nodes $i$ and $i+1$. The latter member also evaluates the state of the flow in the node succeeding node $i$ that follows the direction of traffic flow. Along with a decrease in the speed of traffic flow $i+1$, speed in node $i$ also decreases and on the contrary, an increase in speed in node $i$ leads to an increase in speed in node $i+1$. 
Member $\left(1-\frac{k_{i+1}(t)}{k_{\max , i+1}}\right)^{m_{1}}$ defines a change in traffic acceleration between nodes $\mathrm{i}$ and $i+1$. If vehicle concentration is low in the opposite lane section, the value of the coefficient approaches 1; if concentration is high, then, the value is close to 0 . Thus, an increase in concentration in the opposite lane section causes a decrease in the speed of vehicle flow in road section $i$.

The member $1-\frac{k_{i}(t)}{k_{\max , i}}$ of equation (15) prevents from overloading the system at node $i$. When the value of flow concentration approaches $k_{\max }$, the value of the before mentioned member approaches 0 . Meanwhile, member $\left(\frac{v_{i}(t)}{v_{\max , i}}\right) \cdot e^{\left[\gamma_{3}\left(\frac{k_{i}(t)}{k_{\max , i}}\right)^{m_{2}}\right] \cdot\left(\frac{v_{i}(t)}{v_{\max , i}}\right)}$ evaluates the amount of vehicles at node $i$ and has a direct impact on the meaning of concentration at node $i$.

The amount of vehicles in the lane section is calculated applying the formula

$$
N_{e}=\int_{x_{i}}^{x_{j}} k(x) d x
$$

where $x_{i}$ and $x_{j}$ - marginal nodes of the lane section, $k(x)$ - traffic concentration in the lane section. Changes in the amount of vehicles in the lane section are described in the following form:

$$
N_{i}(t+\Delta t)=N_{i}(t)+\int_{t_{i}}^{\Delta t+t_{i}} q_{i}(t) d t,
$$

where $q(t)$ - the intensity of vehicle flow in lane section $i$.

\section{Comparison of Mathematical Models for Traffic Flows and Experimental Results}

This chapter presents the examples of solving two mathematical models; one is based on the kinetic theory of gases and solved applying the method of characteristics while the other is developed employing the method of concentrated parameters and solved using Runge-Kutta method. Both methods are used for dealing with the same 5 tasks. The obtained results are compared with each other. Allso introduces an example of simulating TF when they are modelled in the urban street network.

The major focus is given onto the model based on the kinetic theory of gases. The theoretical equations describing this model are presented in Section 2. To design the model offered in the example, preconditions discussed in the same Section 2 are applied. 
The investigated example is a straight one lane section having no road branching or additional lanes. The lane is divided into short sections the length of which $-L_{i-1, i}=L_{i+1, i}$ and are equal to $20 \mathrm{~m} / \mathrm{s}$ when $i=1 \ldots 80$. The total length of the lane is $1600 \mathrm{~m}$. The task is solved using the method of characteristics. Therefore, equation system (2.18), (2.19) is solved in every node of the lane apart from marginal ones to establish traffic parameters - concentration and flow speed ( $k$ and $v)$. Marginal nodes contain restrictions required by the method itself. One of the wanted parameters is chosen for the whole simulated time interval in both the first and the last node of the investigated lane. The examined example shows that traffic speed is chosen as the known parameter in the first node, whereas in the last one, traffic concentration is accepted.

Boundary conditions for all five investigated examples are as follows: traffic speed in the first node is $v_{1}=9.72 \mathrm{~m} / \mathrm{s}, 11.11 \mathrm{~m} / \mathrm{s}, 12.5 \mathrm{~m} / \mathrm{s}, 9.72 \mathrm{~m} / \mathrm{s}, 12.5 \mathrm{~m} / \mathrm{s}$ and concentration value in the first node is calculated according to expression

$$
k_{1}^{t+\Delta t}=k_{1}^{t}+C^{-} \cdot J_{2,1} .
$$

Traffic concentration in the last node in all five cases is as follows: $\mathrm{k}_{81}=\mathrm{k}_{\max }=$ 0.18 auto $/ \mathrm{m}, 0.18$ auto $/ \mathrm{m}, 0.18$ auto $/ \mathrm{m}, \mathrm{k}_{81}=\mathrm{k}_{1}, \mathrm{k}_{81}=\mathrm{k}_{1}$ and traffic speed is calculated according to expression

$$
v_{81}^{t+\Delta t}=v_{81}^{t}+C^{+} \cdot J_{1,2} .
$$

Traffic speed in the rest of the nodes is calculated according to expression

$$
v_{81}^{t+\Delta t}=v_{i}^{t}+\Delta v_{i},
$$

whereas traffic concentration is calculated according to expression

$$
k_{i}^{t+\Delta t}=k_{i}^{t}+\Delta k_{i} .
$$

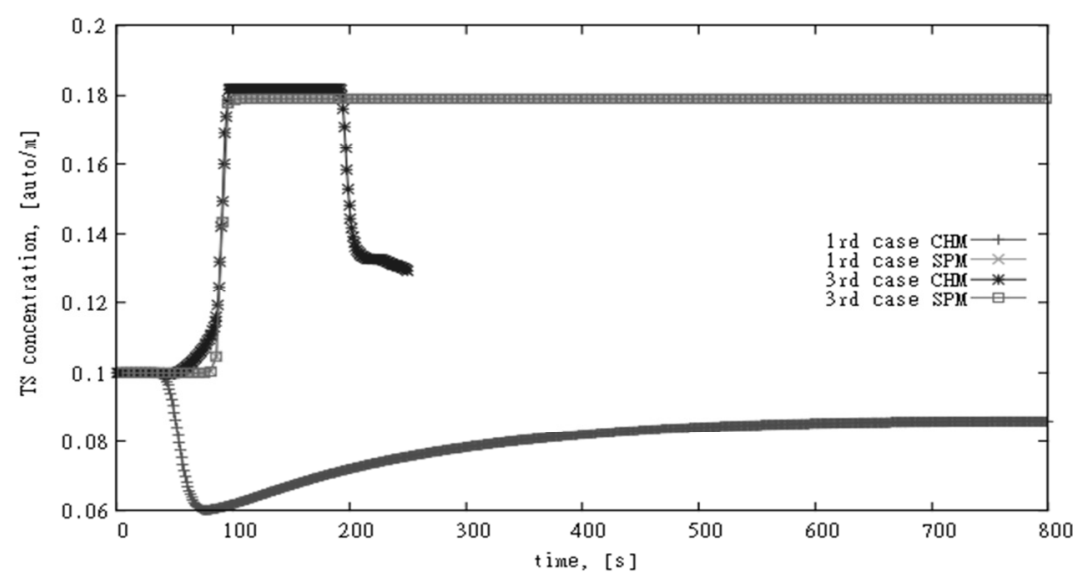

Fig. 4S. A comparison of changes in TF concentration in road section node 40 when mathematical gas kinetic models (CHM) and those with concentrated parameters (SPM) are compared with each other in simulation cases 1 and 3 . 


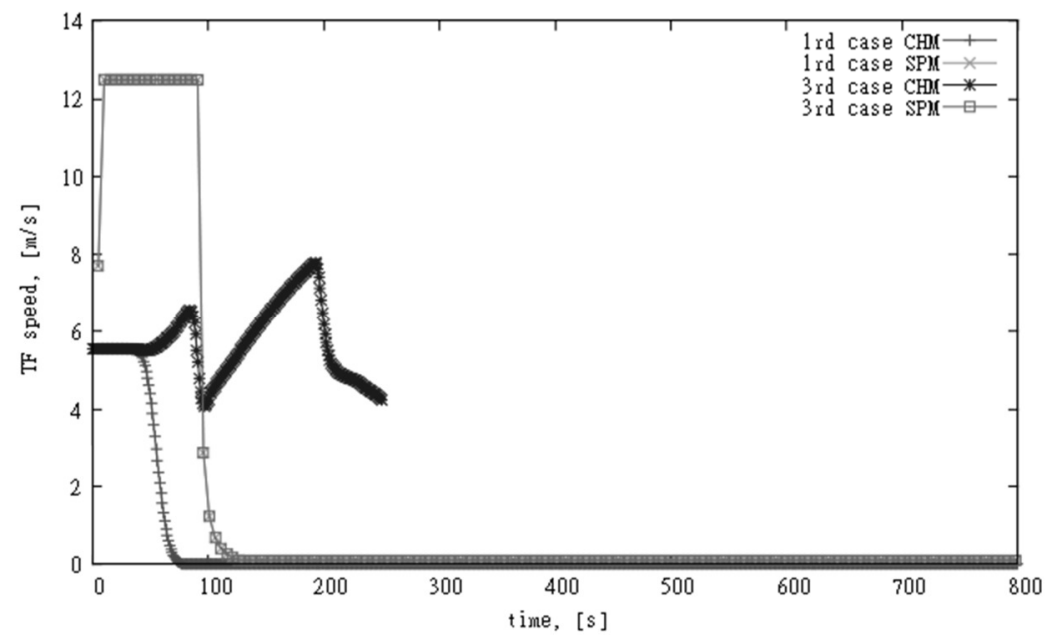

Fig. 5S. A comparison of changes in TF speed in road section node 40 when mathematical gas kinetic models (CHM) and those with concentrated parameters (SPM) are compared with each other in simulation cases 1 and 3 .

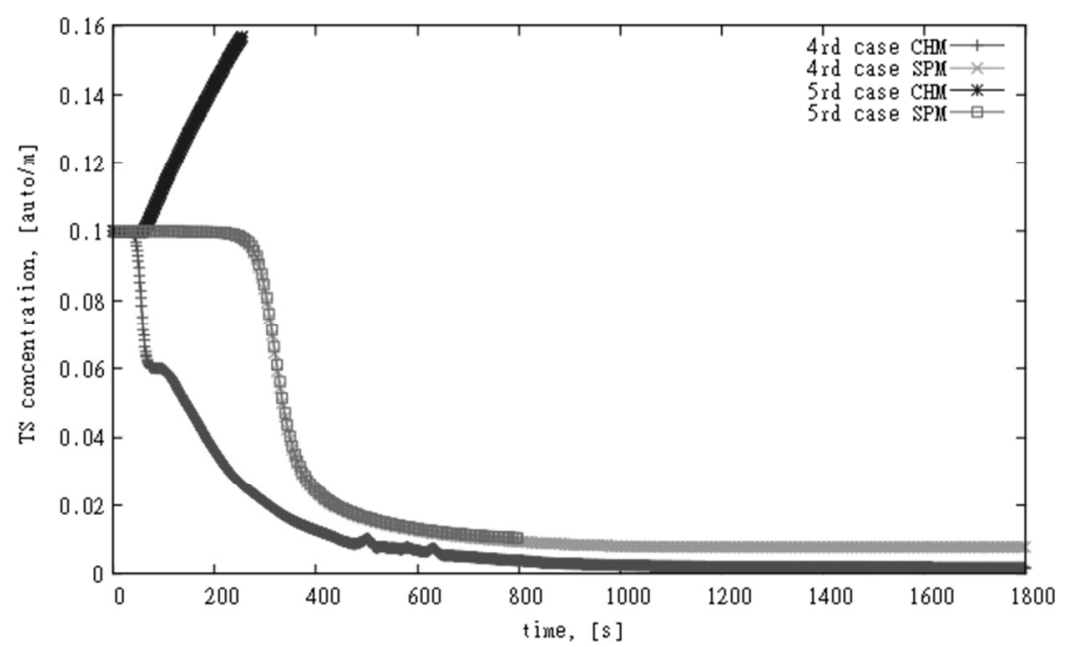

Fig. 6S. A comparison of changes in TF concentration in road section node 40 when mathematical gas kinetic models (CHM) and those with concentrated parameters (SPM) are compared with each other in simulation cases 4 and 5.

To simulate traffic flows in the straight lane section, this chapter presents the examples of the model based on concentrated parameters. The theoretical equations describing the model are introduced in Part 2 To simulate the model given in the example, preconditions provided in Part 2 are applied. 


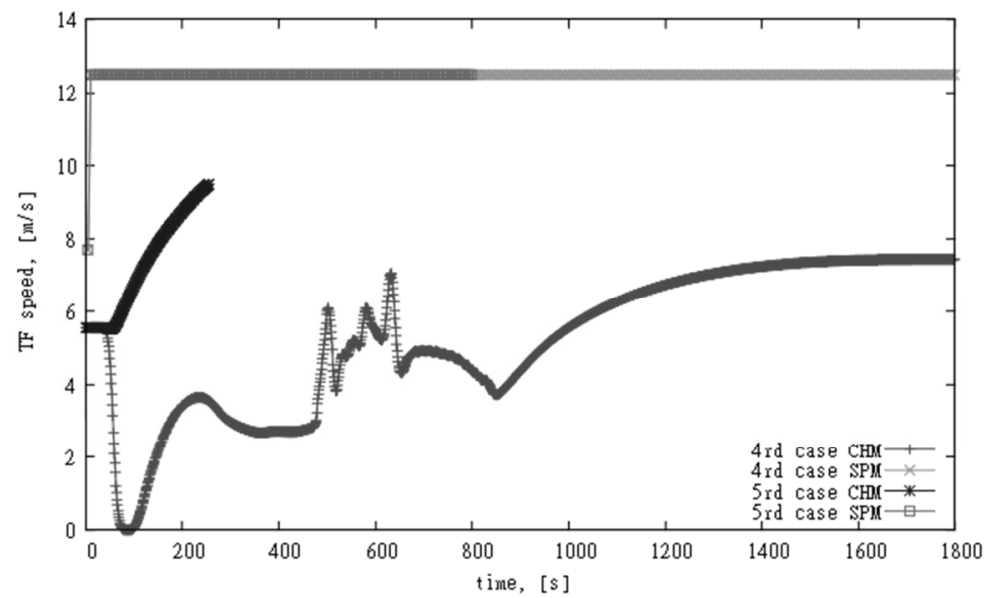

Fig. 7S. A comparison of changes in TF speed in road section node 40 when mathematical gas kinetic models (CHM) and those with concentrated parameters (SPM) are compared with each other in simulation cases 4 and 5.

The formulation of the task is suggested in Section 3. Equation system (14), (15) is solved in every node of the lane apart from marginal ones to establish traffic parameters - concentration and flow speed ( $k$ and $v)$.

Values of traffic speed in all nodes of the lane are as follows: minimum allowable $9.72 \mathrm{~m} / \mathrm{s}$, maximum allowable $12.5 \mathrm{~m} / \mathrm{s}$. Marginal values of traffic concentration in all nodes of the lane are as follows: minimum allowable 0 auto/m, maximum allowable 0.18 auto $/ \mathrm{m}$. At the initial time, TF speed is $5.545 \mathrm{~m} / \mathrm{s}$ and concentration -0.1 auto $/ \mathrm{m}$ at all nodes except from marginal ones.

When simulating the same section in marginal nodes using the developed model and considering every individual case, the following variables of meanings are introduced: TF speed in the first node $-9.72 \mathrm{~m} / \mathrm{s}, 11.11 \mathrm{~m} / \mathrm{s}, 12.5 \mathrm{~m} / \mathrm{s}, 9.72 \mathrm{~m} / \mathrm{s}$, $12.5 \mathrm{~m} / \mathrm{s}$, TF concentration -0.01 auto $/ \mathrm{m}, 0.01$ auto $/ \mathrm{m}, 0.01$ auto $/ \mathrm{m}, 0.01$ auto $/ \mathrm{m}, 0.01$ auto/m; TF speed in the last node $-0.1 \mathrm{~m} / \mathrm{s}, 0.1 \mathrm{~m} / \mathrm{s}, 0.1 \mathrm{~m} / \mathrm{s}, 9.72 \mathrm{~m} / \mathrm{s}, 12.5 \mathrm{~m} / \mathrm{s}$, TF concentration -0.18 auto $/ \mathrm{m}, 0.18$ auto $/ \mathrm{m}, 0.18$ auto $/ \mathrm{m}, 0.01$ auto $/ \mathrm{m}, 0.01$ auto $/ \mathrm{m}$.

To compare the obtained results, node 40 from the straight road section is taken as an example. The node is at an equal distance from the marginal point of the simulated road. The marginal points are distant from the chosen node, and therefore simulation results in this node clearly indicate the state of the whole system and changes in parameters during full-time simulation. Experimental results are graphically compared in the below displayed pictures.

Fig $4 \mathrm{~S}$ and $5 \mathrm{~S}$ compare simulation cases 1 and 2. Due to very similar simulation conditions, exactly these simulation results have been chosen for comparison purposes. TF speed in the first node in both cases is equal to $9.72 \mathrm{~m} / \mathrm{s}$ and TF concentration in the last node equals 0,18 auto $/ \mathrm{m}$.

When applying the method of task characteristics, the second unknown parameter in the first node is TF concentration and can be calculated using expression (20). This 
parameter may vary subject to changes in the meanings in the $2^{\text {nd }}$ node. The second unknown parameter in the last node is TF speed and can be calculated using expression (21). The obtained meanings face some changes depending on 80 meanings of the node.

The application of the Runge-Kutta method for solving the task shows that both unknown parameters in the first and the last node are chosen; therefore, TF concentration in the first node is accepted as 0.01 auto $/ \mathrm{m}$ while in the last node TF speed equals $0.1 \mathrm{~m} / \mathrm{s}$.

Fig $6 \mathrm{~S}$ and $7 \mathrm{~S}$ compares simulation cases 4 and 5 . Due to very similar simulation conditions, exactly these simulation results have been chosen for comparison purposes. TF speed in the first and last node in case 4 equals $9.72 \mathrm{~m} / \mathrm{s}$, whereas in case 5 it makes $12.5 \mathrm{~m} / \mathrm{s}$. The application of the method of characteristics shows that TF concentration in the last node equals the concentration of the first node and is close to 0 auto/m, whereas in case of employing the Runge-Kutta method it makes 0.01 auto $/ \mathrm{m}$.

At the initial moment of time, TF speed and concentration in all cases of simulation remain the same - speed at all intermediate nodes equals $5.55 \mathrm{~m} / \mathrm{s}$ while concentration $0.1 \mathrm{~m} / \mathrm{s}$.

A comparison of the two above discussed methods reveals that due to varying conditions for simulation, the method of concentrated parameters works much more stable and reveals similar results in all cases of simulation.

A kinetic model of gases is very sensitive to changed boundary conditions for the task. The compared 4 cases indicate that simulation has been suspended in 2 cases out of 4 (230 and $250 \mathrm{~s}$ ) as the meanings of TF parameters suddenly started approaching $\infty$. The method needs a lengthy period of time to make speed and concentration values attained at the equilibrium position. The method is steady when the boundary conditions of the task are distant from the highest allowable values of the task. Thus, the latter method can be used for evaluating changes in TF parameters.

The created method of concentrated parameters is successfully employed taking into account different boundary conditions. However, the drawback of the method is that it works close to the marginal values of TF speed and concentration. The drawback can be omitted introducing additional functions $r_{k, i n}, r_{k, \text { out }}, r_{v, i n}, r_{v, \text { out }}$ into equations (14) and (15). The entered functions may vary subject to the calculated values of TF speed and concentration. The character of functions in the thesis has not been disclosed due to the shortage of experimental data.

\section{Comparison of the Results of the Mathematical Model and Experimental Data. Possibilities of the Application of the Created Model}

This chapter makes a comparison between experimental and simulation results and provides with an example of applying the mode in practice. Section 4.1 compares measured and simulated TF parameters. The measured TF parameters are introduced to the first and last points of the examined road section. TF parameters at the intermediate points are calculated using the mathematical expressions of the created model of 
concentrated parameters. The measured data are graphically compared with calculated TF parameters. Section 4.2 presents an example of simulating ICE emission.

\section{General Conclusions}

1. The developed method allows the consideration of traffic flow, as a dynamic system and to assess rapidly changing driving conditions.

2. To simulate the urban street network, the elements of a mathematical model have been created. The settling rate of calculating the developed mathematical model with concentrated parameters is higher than in a traditional mathematical continuum model where the rate varies from 20 to $8000 \mathrm{~s}$. Meanwhile, the settling rate in the model with concentrated parameters is in the range from 5 to $60 \mathrm{~s}$.

3. A comparison of a traditional gas - kinematic model and the obtained results of the mathematical model with concentrated parameters to experimental data reveals analogous tendencies towards changes in traffic speed and concentration. When the value of traffic concentration approaches maximum concentration value traffic speed decreases and approaches maximum speed value and vice versa, when the value of concentration approaches minimal concentration value, the value of speed is getting closer to the maspeed value.

4. The obtained results of the gas - kinematic model and the suggested mathematical model show that the kinematic mathematical model is more stable when the values of flow parameters are approximately $20 \%$ from the possible marginal values.

5. Accuracy between the function, received from the experimental data and the data recieved from the model, is about $8 \%$. The bigger error is on speed values. It can be argued that the model is correct, but it is necessary to clarify the detailed description of the model parameters that depends from the traffic flow speed and concentration.

6. It is proposed the concept of internal combustion emissions forecast. This concept allows to asses the characteristics of the traffic flow dynamic and the influance of number of cars in a given streets network on the formation of exhaust gases. 


\begin{abstract}
A priedas. Rungès ir Kuto metodas
B priedas. Niutono metodas

C priedas. Sukurto modelio kodas FORTRAN programine kalba

D priedas Vidaus degimo variklio emisijų prognozès rezultatai

E priedas. Bendraautorių sutikimai teikti publikacijų medžiagą disertacijoje
\end{abstract}

F priedas. Mokslinių publikacijų disertacijos tema kopijos 
Raimundas JUNEVIČIUS

MODELING OF THE TRAFFIC FLOW USING THE METHOD OF THE CONCENTRATED PARAMETERS IN THE STREETS NETWORK

Scientific Doctoral Dissertation

Technological Sciences,

Transport Engineering (03T)

Raimundas JUNEVIČIUS

TRANSPORTO SRAUTŲ MODELIAVIMAS SUTELKTŲJŲ PARAMETRŲ METODU GATVIŲ TINKLE

Mokslo daktaro disertacija

Technologijos mokslai,

transporto inžinerija (03T)

201107 27. 10,5 sp. I. Tiražas 20 egz.

Vilniaus Gedimino technikos universiteto

leidykla "Technika“",

Saulètekio al. 11, 10223 Vilnius,

http://leidykla.vgtu./t

Spausdino UAB "Ciklonas“,

J. Jasinskio g. 15, 01111 Vilnius 